\title{
GROUND-WATER HYDROLOGY AND QUALITY IN THE LOMPOC AREA, SANTA BARBARA COUNTY, CALIFORNIA, 1987-88
}

By Daniel J. Bright, Christina L. Stamos, Peter Martin, and David B. Nash

U.S. GEOLOGICAL SURVEY

Water-Resources Investigations Report 91-4172

Prepared in cooperation with the

SANTA YNEZ RIVER WATER CONSERVATION DISTRICT

$\frac{0}{8}$ 


\section{U.S. DEPARTMENT OF THE INTERIOR \\ MANUEL LUJAN, JR., Secretary}

\section{U.S. GEOLOGICAL SURVEY \\ Dallas L. Peck, Director}

Any use of trade, product, or firm names in this publication is for descriptive purposes only and does not imply endorsement by the U.S. Government.

For sale by the Books and Open-File Reports Section, U.S. Geological Survey

Federal Center, Box 25425

Denver, CO 80225

For additional information write to:

District Chief

U.S. Geological Survey

Federal Building, Room W-2233

2800 Cottage Way

Sacramento, CA 95825 


\section{CONTENTS}

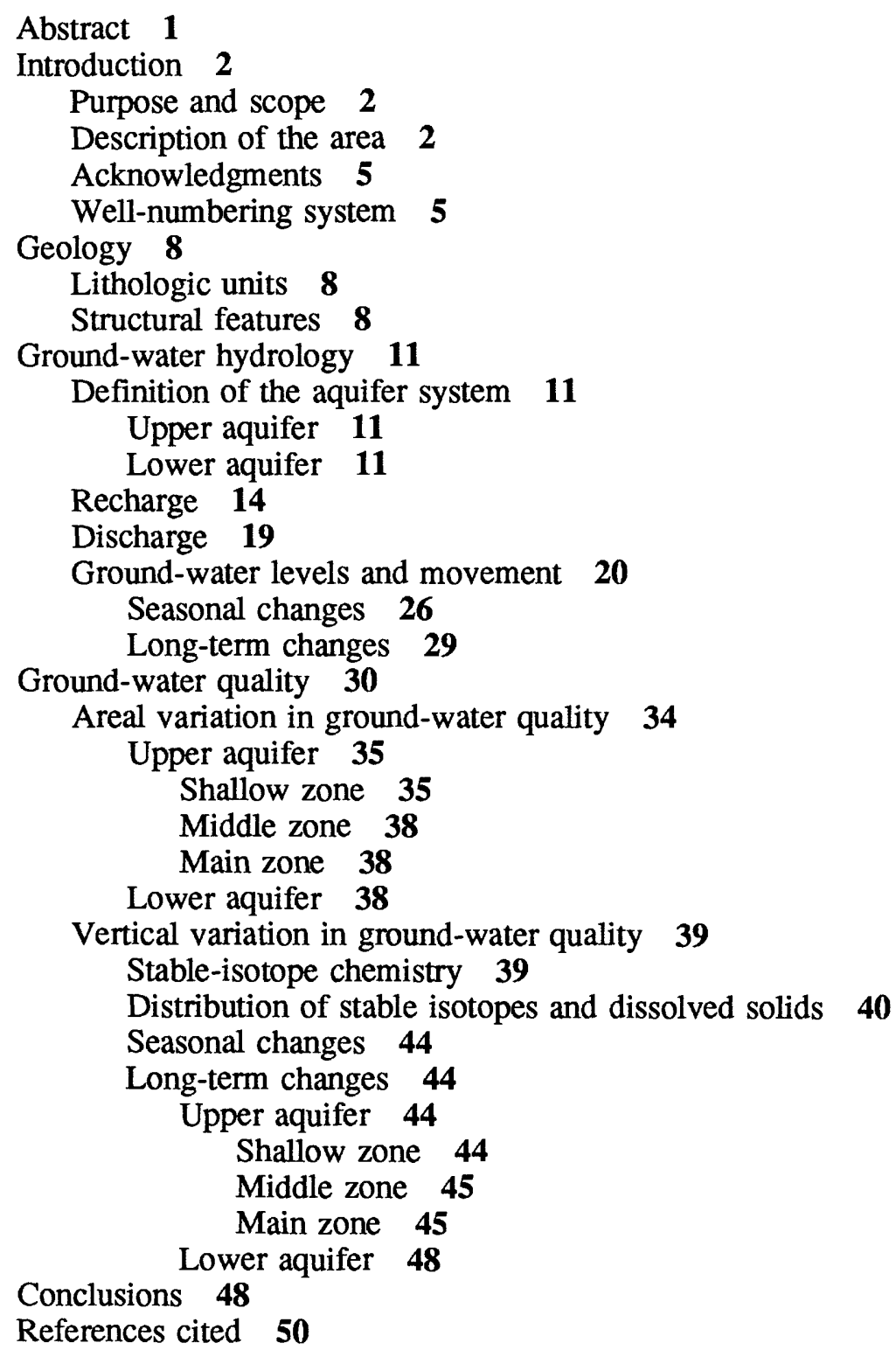

\section{PLATE}

1. Map showing generalized geology and geologic sections of the Lompoc area, Santa Barbara County, California In pocket 


\section{FIGURES}

1-3. Maps showing:

1. Location of study area 3

2. Subdivisions of the Lompoc plain 4

3. Land use, 1985, and location of gaging stations and wastewater-treatment plant 6

4. Areal extent of upper and lower aquifers, and location of geohydrologic sections shown in figure 1413

5. Diagram showing sources of ground-water recharge and discharge in the study area 15

6,7. Graphs showing:

6. Components of annual pumpage in the Lompoc area, 1941-85 17

7. Flow-duration curves for the Santa Ynez River in the Lompoc area 18

8,9. Maps showing:

8. Location of monitor wells and cluster sites 22

9. Potentiometric surfaces of shallow and main zones of upper aquifer, spring 1988, and of lower aquifer, summer 1987 and spring $1988 \quad 25$

10,11. Graphs showing:

10. Altitude of water levels for selected cluster sites, 1987-88 27

11. Altitude of water levels for selected wells in the upper (shallow and main zones) and lower aquifers, 1930-88 30

12. Maps showing distribution of dissolved solids in water samples from the Santa Ynez River (SYR) and from wells perforated in the upper (shallow, middle, and main zones) and lower aquifers, March 1987-December 198837

13. Graph showing relation between delta deuterium and delta oxygen-18 values for samples from selected wells and surface-water sites $\mathbf{4 0}$

14. Generalized geohydrologic sections showing distribution of delta oxygen-18 and dissolved-solids concentration for selected monitor wells, 1987-88 43

15-17. Graphs showing:

15. Dissolved-solids concentration of samples from wells at the central Lompoc plain cluster site $\mathbf{4 4}$

16. Dissolved-solids concentration of samples from selected wells, 1924-88 46

17. Instantaneous discharge and dissolved-solids concentration, Santa Ynez River at Narrows, near Lompoc (station 11133000), 1978-88 48

\section{TABLES}

1. Principal lithologic units and their water-bearing properties 9

2. Estimates of average annual recharge in the Lompoc area for selected periods $\mathbf{1 6}$

3. Measurements of streamflow and sewage effluent along the Santa Ynez River in the Lompoc area, June 16, 198818

4. Estimates of average annual discharge in the Lompoc area for selected periods 19

5. Static water levels for selected monitor wells, summer 1987 and spring 198821

6. Summary of dissolved solids, nitrogen, and stable isotopes in samples from selected wells, lysimeters, and surface-water sites, March 1987-December $1988 \quad 32$

7. Well-construction data $\mathbf{5 2}$

8. Continuous-record water-level measurements, October 1987-December 198856

9. Chemical analyses of ground water in the Lompoc area $\mathbf{5 8}$

10. Chemical analyses for selected streams in the Lompoc area, 1987-88 76 


\section{Conversion Factors}

\begin{tabular}{|c|c|c|}
\hline Multiply & By & To obtain \\
\hline acre & 0.4047 & hectare \\
\hline acre-foot (acre-ft) & 0.001233 & cubic hectometer \\
\hline acre-foot per day (acre-ft/d) & 0.001233 & cubic hectometer per day \\
\hline $\begin{array}{l}\text { acre-foot per day per mile } \\
{[(\text { acre-ft/d }) / \mathrm{mi}]}\end{array}$ & 0.000766 & $\begin{array}{l}\text { cubic hectometer per day } \\
\text { per kilometer }\end{array}$ \\
\hline acre-foot per year (acre-ft/yr) & 0.001233 & cubic hectometer per year \\
\hline cubic foot per second $\left(\mathrm{ft}^{3} / \mathrm{s}\right)$ & 0.02832 & cubic meter per second \\
\hline foot $(\mathrm{ft})$ & 0.3048 & meter \\
\hline gallon per minute ( $\mathrm{gal} / \mathrm{min})$ & 0.06308 & liter per second \\
\hline $\begin{array}{r}\text { gallon per day per square foot } \\
{\left[(\mathrm{gal} / \mathrm{d}) / \mathrm{ft}^{2}\right]}\end{array}$ & 0.04073 & $\begin{array}{l}\text { cubic meter per day per } \\
\text { square meter }\end{array}$ \\
\hline inch (in.) & 25.40 & millimeter \\
\hline inch per year (in/yr) & 25.40 & millimeter per year \\
\hline mile (mi) & 1.609 & kilometer \\
\hline
\end{tabular}

\section{Vertical Datum}

Sea level: In this report "sea level" refers to the National Geodetic Vertical Datum of 1929--a geodetic datum derived from a general adjustment of the first-order level nets of the United States and Canada, formerly called Sea Level Datum of 1929. 


\title{
GROUND-WATER HYDROLOGY AND QUALITY IN THE
}

\section{LOMPOC AREA, SANTA BARBARA COUNTY,}

\section{CALIFORNIA, 1987-88}

\author{
By Daniel J. Bright, Christina L. Stamos, Peter Martin, and David B. Nash
}

\begin{abstract}
The principal water-bearing units in the Lompoc area are the river-channel deposits and younger alluvium that compose the upper aquifer and the Paso Robles Formation and Careaga Sand that compose the lower aquifer. The upper aquifer consists of three water-bearing zones: (1) the shallow zone, (2) the middle zone, and (3) the main zone. The main zone of the upper aquifer has been the primary source of water in the Lompoc plain. The lower aquifer has been the primary source of water in the Lompoc upland and Lompoc terrace.
\end{abstract}

Ground-water movement in the shallow and main zones of the upper aquifer during spring 1988 generally was from east to west. In both zones, ground water moved westward from the Santa Ynez River toward a water-level depression in the eastem plain. Ground-water movement in the lower aquifer during spring 1988 generally was toward the western plain from the surrounding upland and terrace areas.

Water-level measurements indicate that water flowed to the main zone from overlying and underlying waterbearing deposits throughout 1988 in the eastern plain. Ground water moved freely between the upper and lower aquifers in this area. In the central and western plain, water flowed to the main zone from overlying and underlying deposits only during the irrigation season. Downward flow to the main zone in these areas, however, was limited because of the presence of silt and clay deposits in the shallow zone.

The dissolved-solids concentrations in ground water varied markedly throughout the Lompoc plain. In general, the dissolved-solids concentrations in the shallow, middle, and main zones increased from the eastern plain to the western plain. In areas adjacent to the Santa Ynez River that have had little, if any, history of agricultural activity, dissolved-solids concentrations in the shallow zone were about 1,000 milligrams per liter. However, in areas that have been irrigated, dissolved-solids concentrations commonly were greater than 3,000 milligrams per liter. Dissolved-solids concentrations of ground water in the shallow zone were more than twice those in the main zone and several times higher than in the lower aquifer. Dissolved-solids concentrations of water in the shallow zone were greater than 8,000 milligrams per liter near the coast.
In the northeastern plain, high dissolved-solids concentrations (2,900 milligrams per liter) of water in the middle zone were attributed to leakage from the overlying shallow zone. This water of high dissolved-solids concentration was diluted by recharge of water from the southern edge of the plain as it moved downgradient toward the western plain. Downward leakage through silt and clay deposits in the shallow zone was limited in areal extent, as indicated by the presence of water of low dissolved-solids concentration (650 milligrams per liter) in the middle zone beneath the western plain.

Data collected from this and other studies indicate that ground-water quality has deteriorated steadily in many areas of the Lompoc plain from the 1950's to 1988. Concentrations of dissolved solids in the main zone have increased throughout the Lompoc plain. Pumping for irrigation and for municipal use in the eastern plain has intercepted a large percentage of the recharge from the Santa Ynez River since the 1950's. The cone of depression caused by this pumping has induced downward movement of water of high dissolved solids concentration from the shallow zone into the main zone. Unlike the middle zone, in which the dissolved-solids concentrations decreased in the western plain, dissolvedsolids concentrations of water in the main zone remained high throughout the plain. High concentrations of dissolved solids in the upper aquifer along the coast during 1987-88 were attributed to downward leakage of seawater from the overlying estuary.

In general, ground water in the lower aquifer had significantly lower dissolved-solids concentrations than water in the upper aquifer during 1987-88. The lower aquifer beneath the Lompoc plain contained water of slightly higher dissolved-solids concentration than water in the aquifer beneath the Lompoc upland; the major source of recharge to the lower aquifer beneath the Lompoc upland was direct infiltration of precipitation. Water-quality samples from wells at the base of the canyons that drain the foothills of the Santa Ynez Mountains suggest that recharge of runoff from the foothills probably contributed significant quantities of dissolved solids to the lower aquifer beneath the Lompoc plain. Also, the direct contact between the shallow zone and the lower aquifer at the southern edge of the plain probably allowed irrigation-return flow to percolate into the lower aquifer. 


\section{INTRODUCTION}

Ground water historically has been the main source of water supply in the Lompoc area of the Santa Ynez River basin (fig. 1). Construction of the missile facilities at Vandenberg Air Force Base (VAFB) in the 1960's and increased population growth in the 1980's have significantly increased the demand for water in the Lompoc area for domestic and municipal uses. In addition, there continues to be a large demand for ground water for irrigation on the Lompoc plain, which is the principal agricultural area in the Santa Ynez River basin.

Ground water in the Lompoc area in 1983, especially in the Lompoc plain, was only marginally acceptable for most uses. Dissolved-solids concentration of ground water in the western Lompoc plain has increased from an average of $1,260 \mathrm{mg} / \mathrm{L}$ (milligrams per liter) in the mid-1930's (Wilson, 1959, p. 103) to more than $3,000 \mathrm{mg} / \mathrm{L}$ by 1983 (Berenbrock, 1988). Dissolved-solids concentration of ground water from the surrounding Lompoc upland and terrace areas, however, has not changed appreciably in the last 50 years (Ahlroth and others, 1977). Several studies have documented the deterioration of ground-water quality in the Lompoc plain (Wilson, 1959; Evenson, 1966; Miller, 1976; Berenbrock, 1988). These studies suggested that recharge by irrigation-return flow may have been the principal cause of the deterioration. If ground-water quality continues to deteriorate, the ground water will become unusable for most purposes, including irrigation, without some treatment. Because the demand for ground water in the Lompoc area has continued to increase, the Santa Ynez River Water Conservation District entered into a cooperative program with the U.S. Geological Survey in 1986 to study ground-water-quality conditions in the Lompoc area.

\section{PURPOSE AND SCOPE}

A two phase approach was used to study groundwater-quality conditions in the Lompoc area. The purpose of this report on the first phase of the study is to describe the ground-water hydrology and quality of the Lompoc area of the Santa Ynez River basin. The planned second phase of the study is the application of a ground-water-flow model for the Lompoc area and a solute-transport model for the Lompoc plain. Both models will be useful for evaluating the potential effectiveness of ground-water management plans prior to their implementation. This report:
1. Describes the geohydrologic framework of the Lompoc area, with particular emphasis on the geologic structure of the unconsolidated Tertiary deposits.

2. Summarizes and evaluates estimates of recharge and discharge from previous studies.

3. Describes vertical variation in water quality and the degree of hydraulic connection between aquifers in the Lompoc plain.

4. Evaluates possible sources for groundwater quality degradation in the Lompoc plain.

\section{DESCRIPTION OF THE AREA}

The Lompoc area is on the west coast of Santa Barbara County (fig. 1). The study area is in the Lompoc hydrologic subunit of the Santa Ynez hydrologic unit (California Department of Water Resources, 1964) and includes the Lompoc plain, the Lompoc terrace, and the Lompoc upland. The Lompoc plain, terrace, and upland are bordered on the north by the Purisima Hills, on the east by the Santa Rita Hills, on the south by the foothills of the Santa Ynez Mountains, and on the west by the Pacific Ocean. For this report, the Lompoc plain is subdivided into nine areas (fig. 2) to aid in the description of waterquality conditions.

The Lompoc area has a typical coastal climate of warm, dry summers and cool, wet winters. Coastal fog is common in the valley throughout the year. Practically all the precipitation occurs from November through April. The average annual precipitation at Lompoc during 1951-88 was 14.2 in., ranging from a minimum of 6.42 in. in 1956 to a maximum of 32.66 in. in 1983 (U.S. Department of Commerce, Weather Bureau, 1954-76 and 1958; National Oceanic and Atmospheric Administration, 1976-88).

The area is drained by the Santa Ynez River and its tributaries. Perennial surface flow in the river has occurred only in the northern plain and coastal area where it has been maintained by sewage effluent and by ground-water discharge, and irrigation runoff, respectively. Several small streams, some with perennial flow, enter the Lompoc plain from the south. Ephemeral streams drain the north side of the basin and the Lompoc terrace area. 


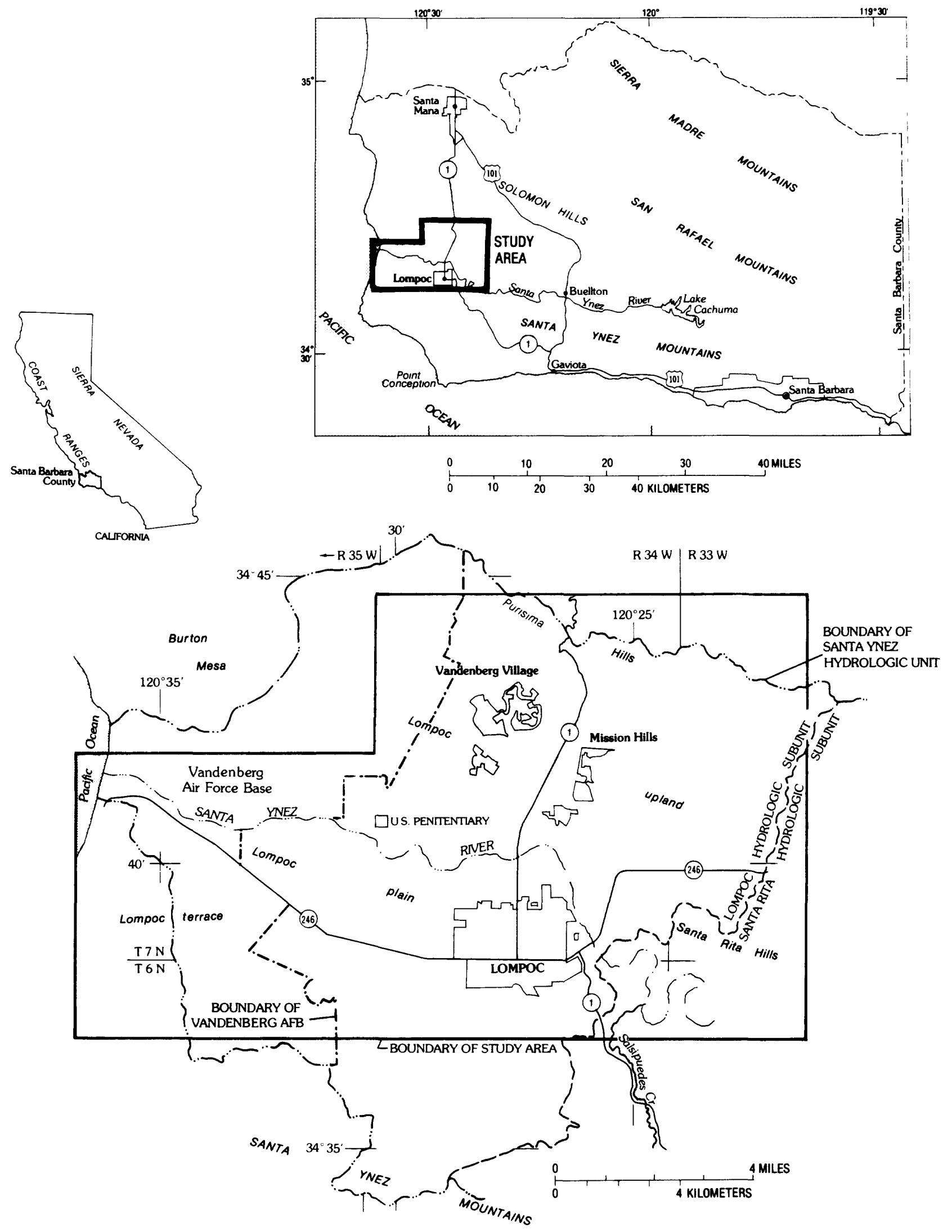

Figure 1. Location of study area. 


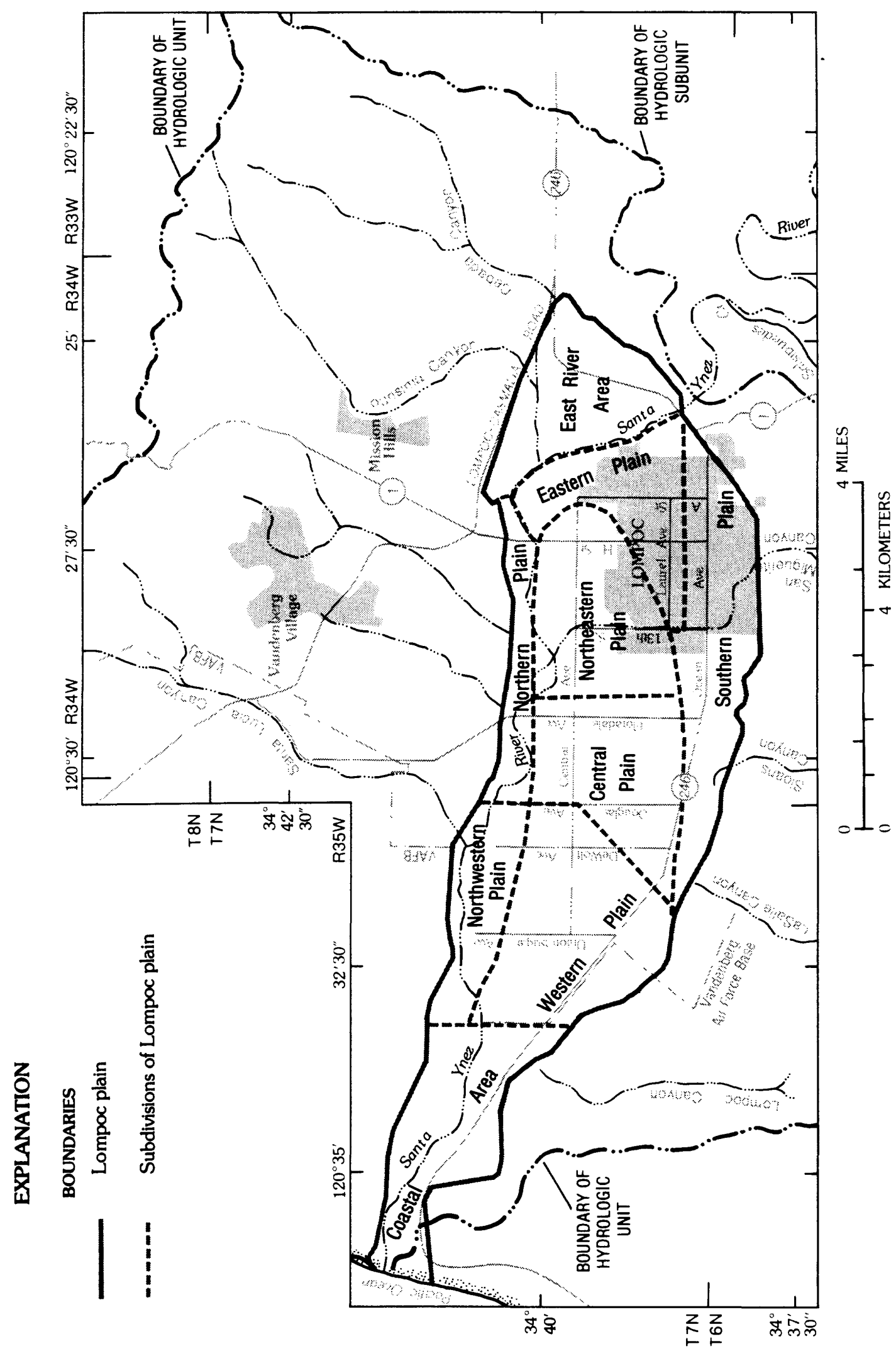

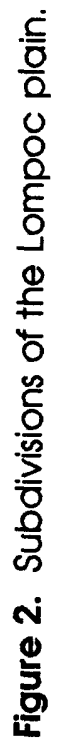


Land in the study area has been used primarily for agriculture. Historically, the uplands were used for dry farming or pastureland and the flatlands for irrigated farming. Figure 3 shows the distribution and percentages for land-use categories in 1985 (California Department of Water Resources, 1987). The land-use categories include urban/suburban, irrigated agriculture, nonirrigated agriculture, and native vegetation. The main urban areas include the city of Lompoc in the eastern plain and the communities of Vandenberg Village and Mission Hills in the Lompoc upland. The western quarter of the area is occupied by Vandenberg Air Force Base (VAFB).

\section{ACKNOWLEDGMENTS}

Individuals within each of the following agencies kindly provided hydrologic data for this investigation and are gratefully acknowledged: Gary Keefe, Virgil Godsey, Richard Wise, and Dale Ducharme of the city of Lompoc; Jon Ahlroth of the Santa Barbara County Water Agency; Christopher Reeves of the U.S. Bureau of Reclamation; Thomas Hom, Richard Nichols, Donald Griggs, and Bert Johnson of Vandenberg Air Force Base; David Aguayo of the Federal Correctional Institution; Roger Brett of Park Water Co.; John Lewis and Kathy Schlottmann of Mission Hills Community Services District; Virginia Wilkinson of the Santa Ynez River Water Conservation District; and Thomas Stetson of Stetson Engineers Inc. The cooperation extended by Steve Jordan of Jordan Brothers Ranch, and by Robert Witt and Jon Anderson of Robert Witt Ranch, in allowing access to data-collection sites on private land is greatly appreciated. The authors also express their gratitude to the following colleagues in the U.S. Geological Survey: Theresa Presser and Mark Hubner of the Branch of Regional Research, Western Region, and Irving Friedman of the Branch of Isotope Geology, Central Region, for their assistance with oxygen-18 and deuterium isotope analyses.

\section{WELL-NUMBERING SYSTEM}

Wells are numbered according to their location in the rectangular system for subdivision of public lands. For example, in well number $7 \mathrm{~N} / 35 \mathrm{~W}-33 \mathrm{~J} 2$, the number and letter preceding the slash indicate the township (T. $7 \mathrm{~N}$.); the number and letter following the slash indicate the range (R. $35 \mathrm{~W}$.); the number following the hyphen indicates the section (sec. 33); the letter $(J)$ following the section number indicates the 40-acre subdivision. Wells are sequentially numbered in the order they are inventoried (number 2). The final letter (S) [for San Bernardino] indicates the base line and meridian. The area covered by this report lies entirely in the northwest quadrant of the San Bernardino base line and meridian. The final (S) is deleted in illustrations and tables. The letters (LYS) following the sequence number indicates a lysimeter.

To find wells and lysimeters on maps in this report, use the diagram below in conjunction with township and range designations at map margins.

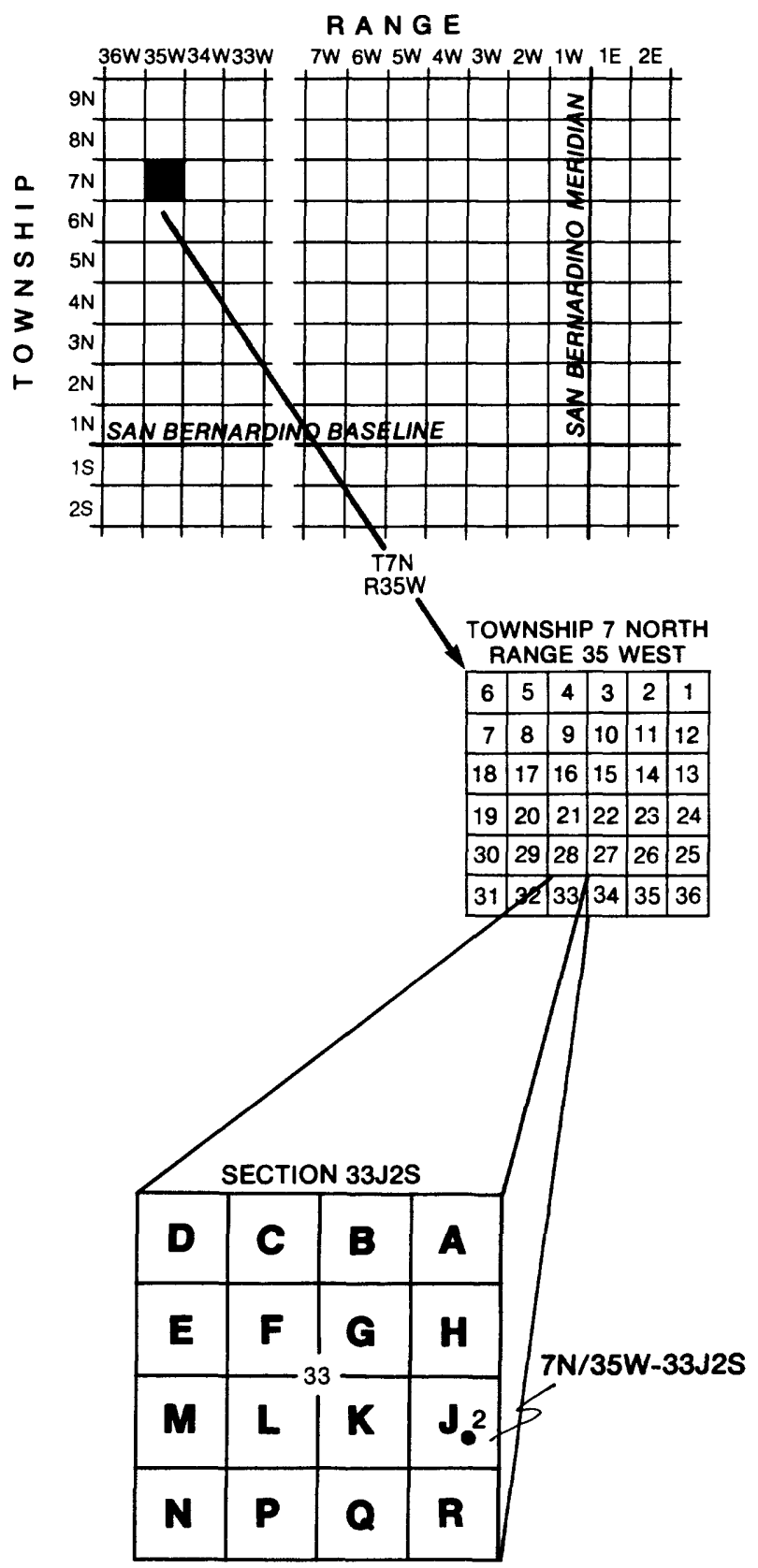




\section{EXPLANATION}

\section{LAND USE}

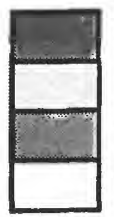

Urban/suburban

Irrigated agriculture

Nonirrigated agriculture

Native vegetation

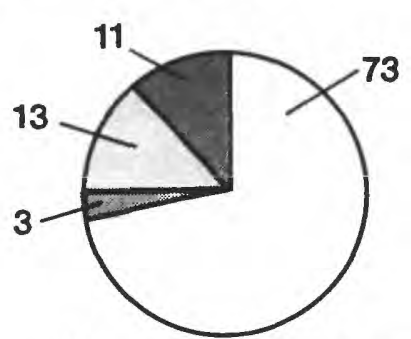

Percentage of total area
BOUNDARY OF LOMPOC PLAIN

SUBDIVISION BOUNDARIES OF LOMPOC PLAIN LOMPOC REGIONAL WASTEWATER TREATMENT PLANT (LRWTP)

STREAM GAGING STATION Santa Ynez River at the Narrows

4 STREAM GAGING STATION, DISCONTINUED - Santa Ýnez River:

2 Near Lompoc (Robinson Bridge)

3 At H Street

5 At 13th Street

4 At 13th Street

6 At Barrier
$\mathrm{R} 35 \mathrm{~W}^{120^{\circ} 30^{\prime}} \mathrm{R} 34 \mathrm{~W}$

(1)

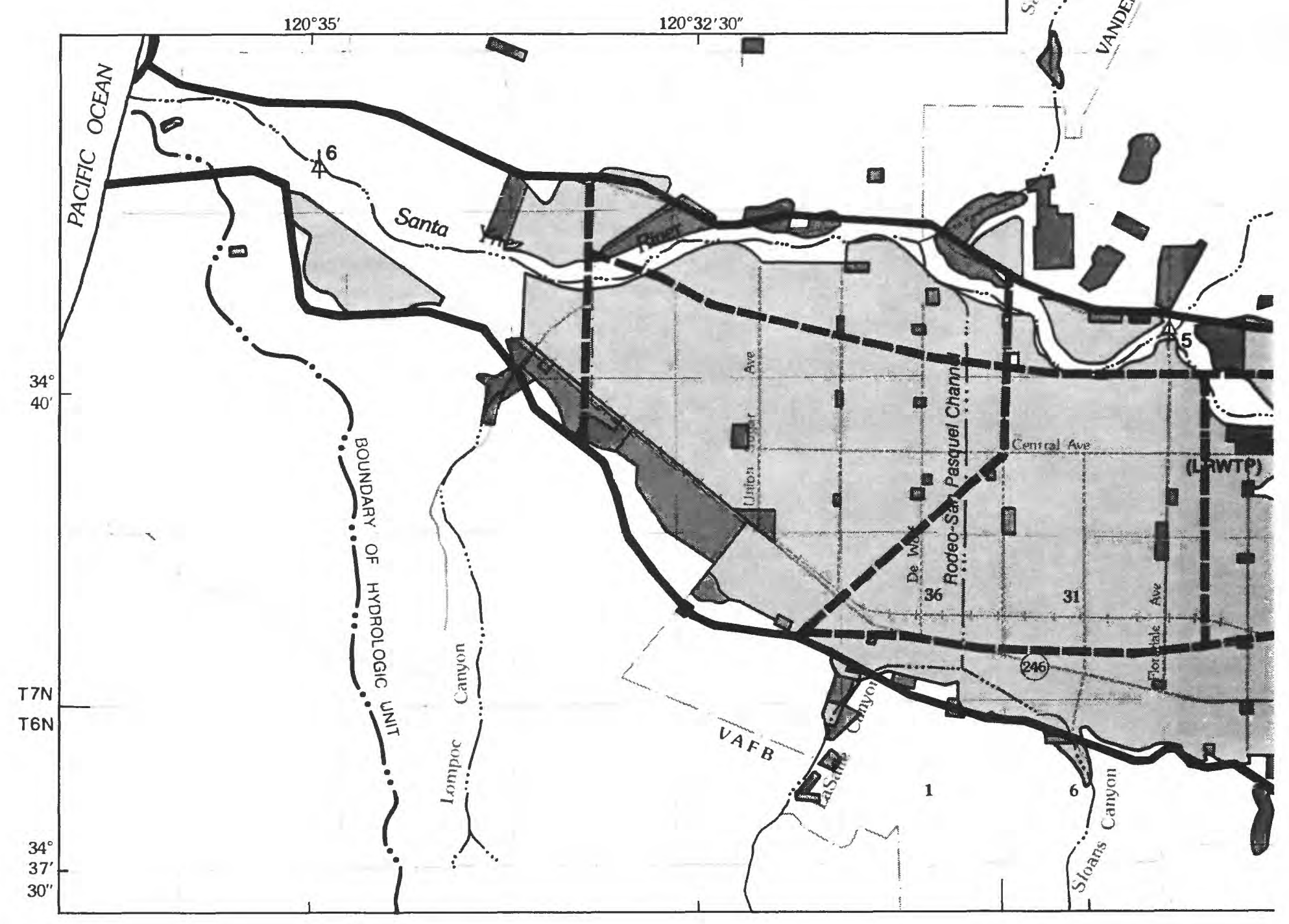

Figure 3. Land use and location of gaging stations and wastewater-treatment plant, 1985. 


\section{GEOLOGY}

The geology of the Lompoc plain and surrounding areas was discussed in detail in reports by Dibblee (1950), Woodring and Bramlette (1950), Upson and Thomasson (1951), and Miller (1976). The geologic analysis presented in this report summarizes these reports, with an emphasis on the lithology of the consolidated rocks and unconsolidated deposits and on the structure of the basin that underlies the Lompoc area.

\section{LITHOLOGIC UNITS}

For this report, the lithologic units mapped by Dibblee (1950) in the Lompoc area were placed in two general categories: (1) consolidated rocks, which underlie the ground-water basin and crop out in the surrounding hills; and (2) unconsolidated deposits, which form the ground-water basin. The outcrop pattern of these units and their stratigraphic and structural relations are shown on plate 1 .

The consolidated rocks, predominantly marine in origin, are nearly impermeable--except for slightly permeable sandstone and in fracture zones. In comparison with the unconsolidated deposits, the consolidated rocks have not been an important source of ground water, and for the purposes of this report they are considered the lower boundary of the groundwater basin.

The unconsolidated deposits generally are highly porous, and the coarser deposits transmit water readily. These deposits have been divided into eight units on the basis of lithologic character and occurrence and water-bearing properties. The principal lithologic units and their water-bearing properties are summarized in table 1.

\section{STRUCTURAL FEATURES}

The geologic structure of the Lompoc area is dominated by a series of anticlinal and synclinal folds (pl. 1). These structures determined the areas in which the unconsolidated deposits could accumulate and thus the thickness of the ground-water basin.

The Santa Ynez Mountains bound the Lompoc area on the south. These mountains are offset by a large fault (pl. 1) that extends from the Lompoc terrace eastward to Lake Cachuma (fig. 1; Sylvester and Darrow, 1979). This fault is referred to as the Santa Ynez River fault (Sylvester and Darrow, 1979) in this report, but it also has been called the LompocSolvang fault in earlier studies (Hall, 1978). In the Lompoc terrace, the fault separates the Careaga Sand from older consolidated deposits on the south (pl. 1). East of La Salle Canyon, the exact location of the fault in the Lompoc area is unknown (A.G. Sylvester, University of California, Santa Barbara, oral commun., 1989).

The greatest thickness of unconsolidated deposits (more than 1,500 $\mathrm{ft}$ ) in the Lompoc area occurs in the trough created by the Santa Rita syncline immediately north of the Santa Rita Hills (pl. 1). The Santa Rita syncline extends eastward through the Santa Rita Valley toward Buellton (fig. 1) and also is believed to swing to the west-southwest beneath the Lompoc plain, where the axis of the syncline plunges gently eastward. The plunge of the Santa Rita syncline has caused Tertiary consolidated rocks to be uplifted and exposed at the westem end of the Lompoc plain. The Tertiary deposits underlying the Lompoc plain dip to the east, becoming progressively younger from the westem to eastem ends of the plain. The Orcutt Sand, terrace deposits, and younger alluvium, which are relatively undisturbed by folding, unconformably overlie the Tertiary deposits.

A west-to-northwest-trending anticline lies beneath the southern part of the Lompoc upland and the northeast part of the Lompoc plain. This anticline uplifts the Careaga Sand to near land surface in the southwestern part of the Lompoc upland near the Santa Ynez River (pl. 1). For the purposes of this report, this anticline is referred to as the Burton Mesa anticline. The Burton Mesa anticline probably is the eastward extension of the anticlinal upwarp exposed over a large part of the Burton Mesa (pl. 1), as mapped by Dibblee (1950, pl. 1, p. 52).

North of the Burton Mesa anticline, a series of northwestward-trending folds form the synclinal trough beneath the Lompoc upland (pl. 1, geologic map and sections $C-C^{\prime}$ and $D-D^{\prime}$ ), The unconsolidated deposits reach a maximum thickness of about $1,500 \mathrm{ft}$ north of Mission Hills in the northern end of the synclinal trough.

The Lompoc upland is bounded on the north by an anticline that forms the Purisima Hills and locally is called the Purisima anticline (pl. 1). Consolidated non-water-bearing rocks are exposed in the central part of the anticline. 


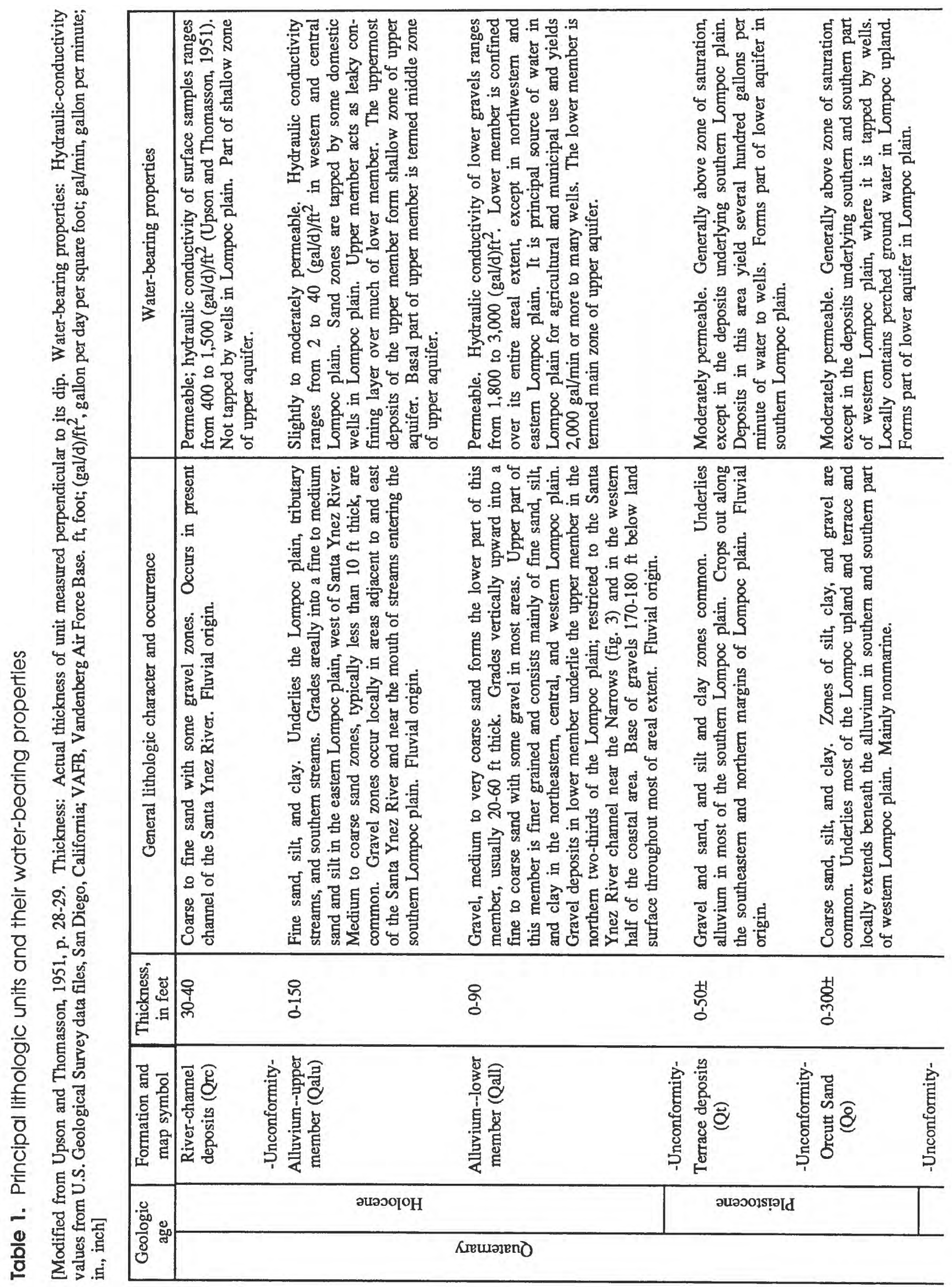




\begin{tabular}{|c|c|c|c|c|}
\hline 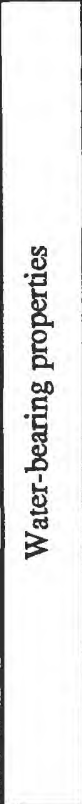 & 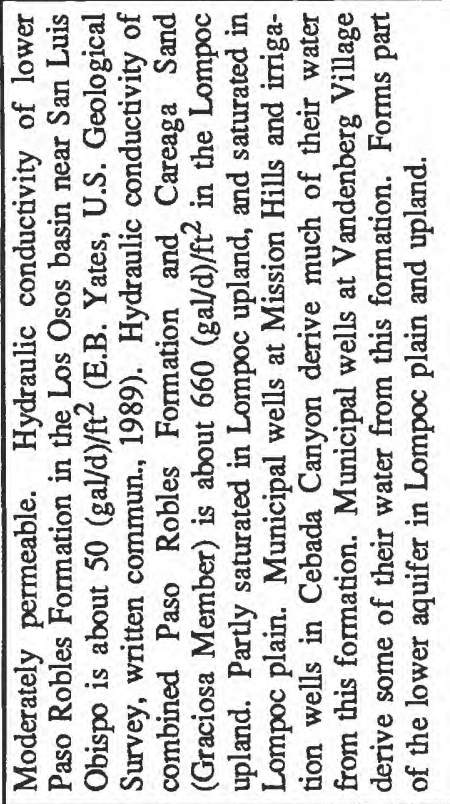 & 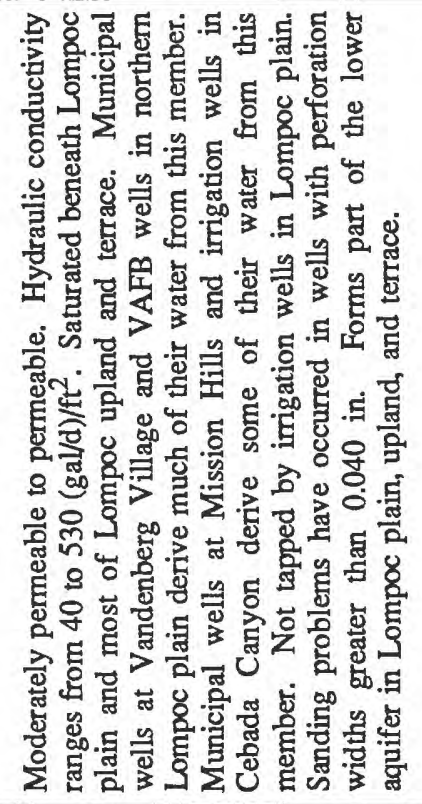 & 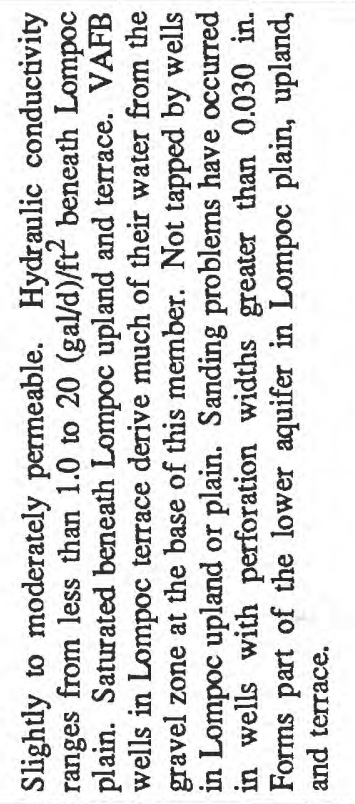 & 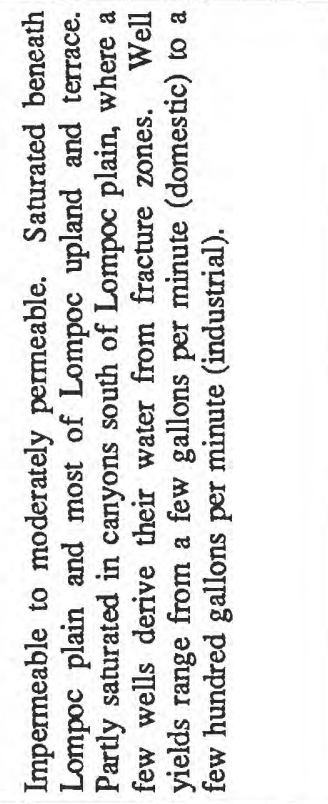 \\
\hline 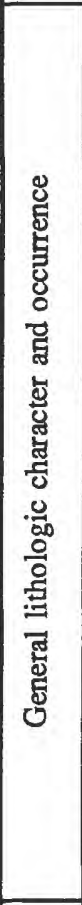 & 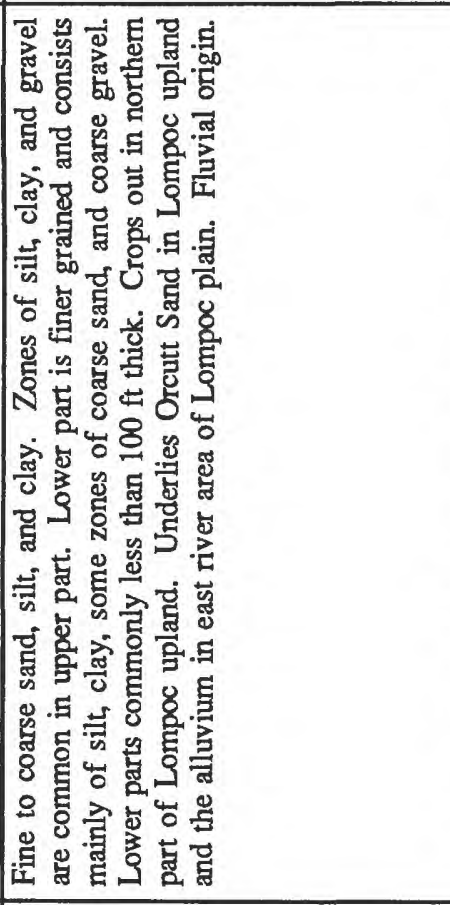 & 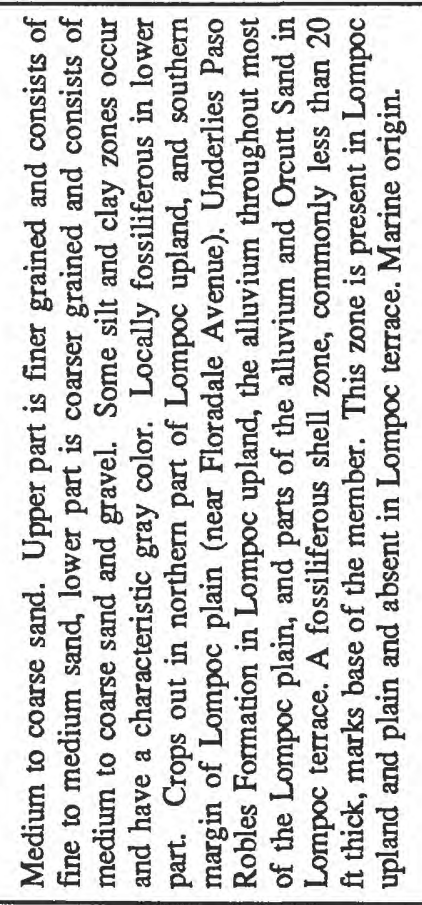 & 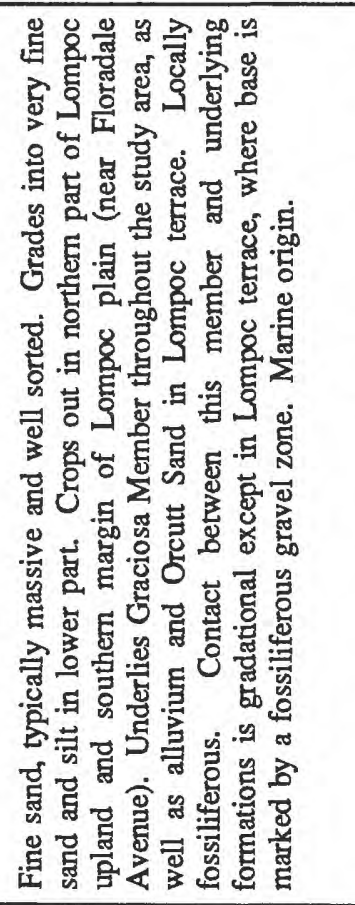 & 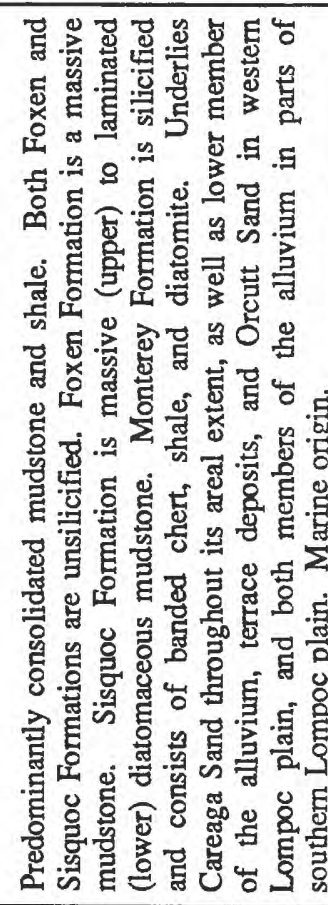 \\
\hline 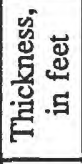 & 声 & $\begin{array}{l}\text { 菅 } \\
\text { 号 }\end{array}$ & $\begin{array}{l}\text { 菅 } \\
\text { ஸे } \\
\text { on }\end{array}$ & 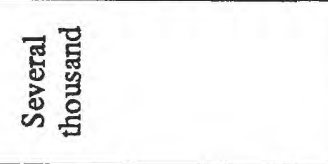 \\
\hline 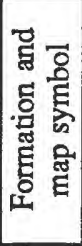 & 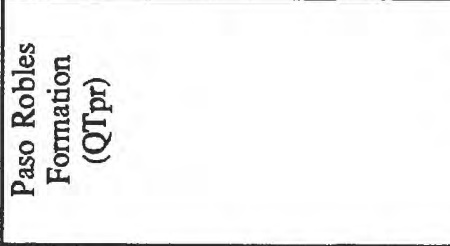 & 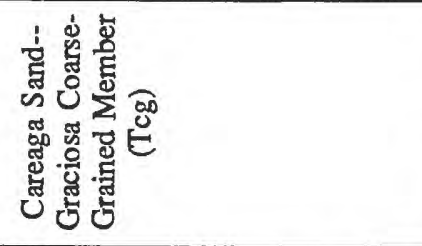 & 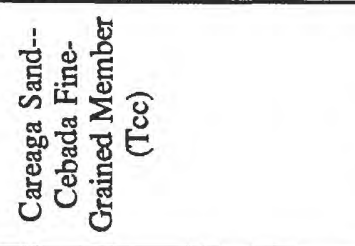 & 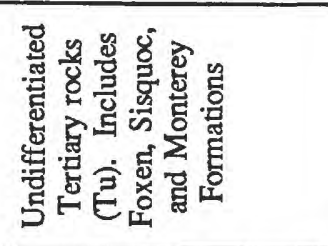 \\
\hline \multirow{2}{*}{$\mid \begin{array}{l}0 \\
00 \\
00 \\
80 \\
0 \\
0\end{array}$} & 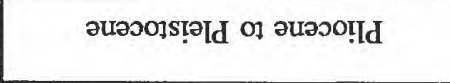 & \multicolumn{2}{|c|}{ วuəวo!ld } & วนəวо!W \\
\hline & Кreسəุen & & & \\
\hline
\end{tabular}




\section{GROUND-WATER HYDROLOGY}

\section{DEFINITION OF THE AQUIFER SYSTEM}

The principal water-bearing units in the Lompoc area are the river-channel deposits and alluvium of Holocene age, the Paso Robles Formation of Pliocene and Pleistocene (?) age, and the Careaga Sand of Pliocene age. The terrace deposits and Orcutt Sand of Pleistocene age are highly permeable but are unsaturated throughout most of the Lompoc upland and terrace. For the purpose of this report, all these units were grouped into two aquifers: (1) the upper aquifer and (2) the lower aquifer.

\section{UPPER AQUIFER}

The upper aquifer includes the river-channel deposits and the alluvium and is limited approximately to the area of the Lompoc plain. On the basis of geologic and electric logs of selected wells (pl. 1), the upper aquifer was subdivided into three zones: (1) the shallow zone, (2) the middle zone, and (3) the main zone (fig. 4).

The shallow zone includes the river-channel deposits and the shallow deposits of the upper member of the alluvium. The river-channel deposits consist of sand and gravel and are 30 to $40 \mathrm{ft}$ thick. These deposits occur beneath the present channel of the Santa Ynez River (fig. 4). The shallow deposits of the alluvium consist predominantly of fine sand, silt, and clay of low permeability in the western, central, and northeastern plain (fig. 4). These lowpermeability deposits confine or partly confine the underlying deposits. Beneath the eastern plain, the shallow deposits grade into a fine to medium sand with occasional gravel and clay layers. The average thickness of the shallow zone is $50 \mathrm{ft}$.

Beneath most of the Lompoc plain, the base of the upper member of the alluvium contains fine sand, silt, and clay deposits interbedded with lenses of permeable sand and gravel. These sand and gravel lenses range from 5 to $40 \mathrm{ft}$ in thickness. The base of the upper member of alluvium is referred to as the middle zone in this report. Previous investigators (Upson and Thomasson 1951, p. 12; Miller, 1976, p. 21) considered these lenses to be part of the shallow zone. However, the lenses beneath the western plain contained ground water of better quality (lower dissolved-solids concentration) than either the overlying shallow zone or the underlying main zone in 1988, indicating that the lenses should be classified as a separate zone.
The main zone includes the lower member of the alluvium and consists largely of medium to coarse sand and gravel. Most of the production wells in the Lompoc plain were perforated in this zone. Throughout most of the plain the sands and gravels of the main zone are separated from the middle zone by lenses of silt and clay. These lenses of lowpermeability silt and clay confine or partly confine the sand and gravel deposits in the main zone. In the eastern plain and northwestern plain, the silt and clay layers are less continuous or absent; as a result, ground water moved freely between the shallow, middle, and main zones in 1988. In the southern plain, the sand and gravel deposits in the main zone are absent, and the fine deposits in the shallow and middle zones also are less continuous or absent (Upson and Thomasson, 1951, p. 146). Thus, ground water moved freely between the shallow and middle zones of the upper aquifer and the lower aquifer beneath the southern plain in 1988 .

\section{LOWER AQUIFER}

The lower aquifer includes the terrace deposits, Orcutt Sand, Paso Robles Formation, and the Careaga Sand. This aquifer is present beneath the Lompoc upland, beneath the upper aquifer throughout the eastern two-thirds of the Lompoc plain, and beneath the Lompoc terrace (fig. 4). The lower aquifer is the primary aquifer in the Lompoc upland and Lompoc terrace. Beneath the Lompoc plain, the lower aquifer has not been used as a source of water, except by VAFB on the north side of the plain.

The terrace deposits consist of gravel and sand with occasional silt and clay layers. The Orcutt Sand consists of coarse sand, silt, and clay. Both of these units are highly permeable, but they are generally unsaturated, except in the southern plain and southern part of the western plain. Beneath the Lompoc upland, the Orcutt Sand locally contains perched ground water. Water levels in wells that tapped these perched zones in 1972 generally were more than 100 $\mathrm{ft}$ higher than levels in the underlying Paso Robles Formation and Careaga Sand (Miller, 1976, p. 24).

The Paso Robles Formation consists of fine to coarse sand, silt, and clay. This unit forms a major part of the lower aquifer beneath the Lompoc upland and beneath the east river area of the Lompoc plain. In the remaining parts of the study area, the formation is either unsaturated or not present. 

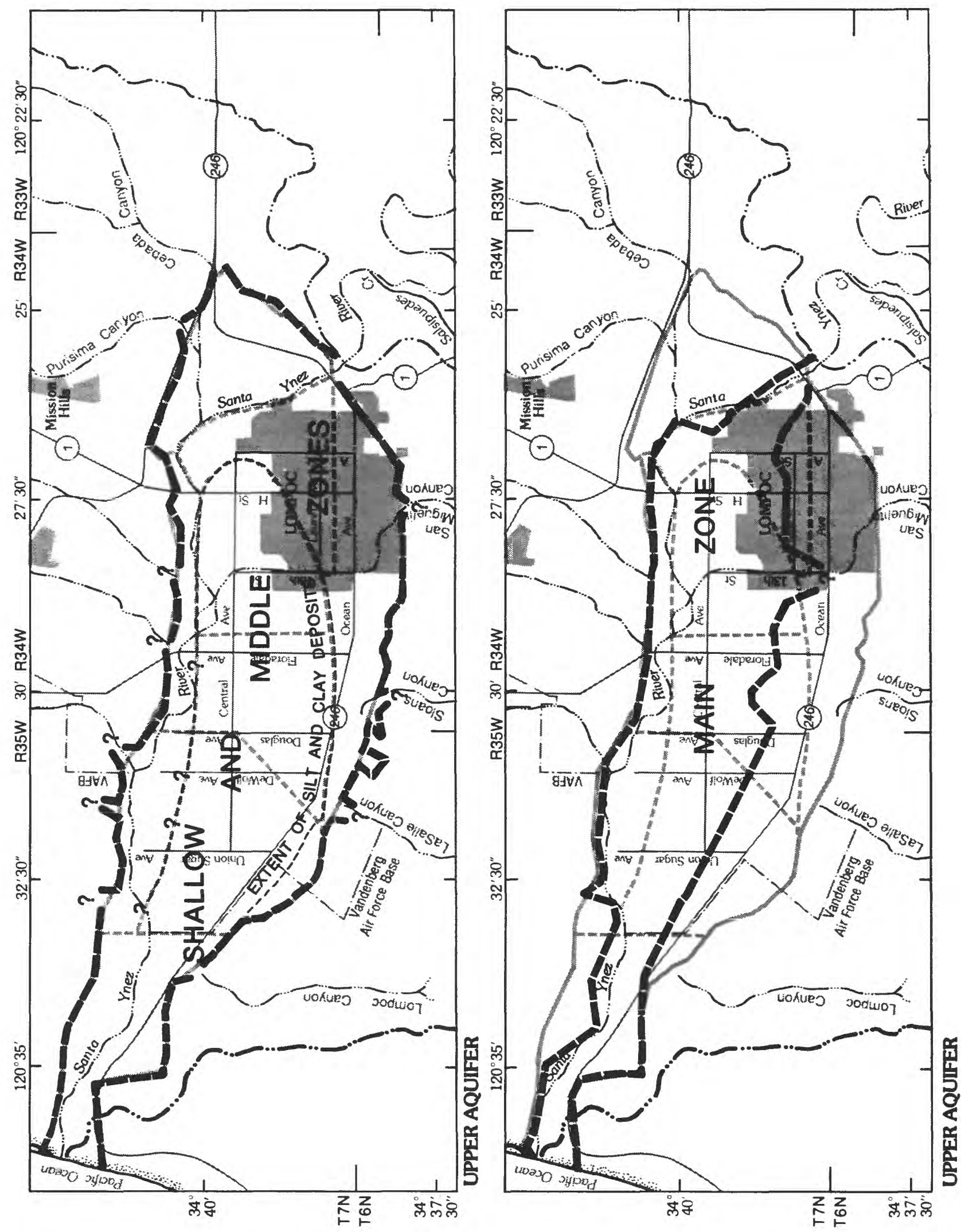


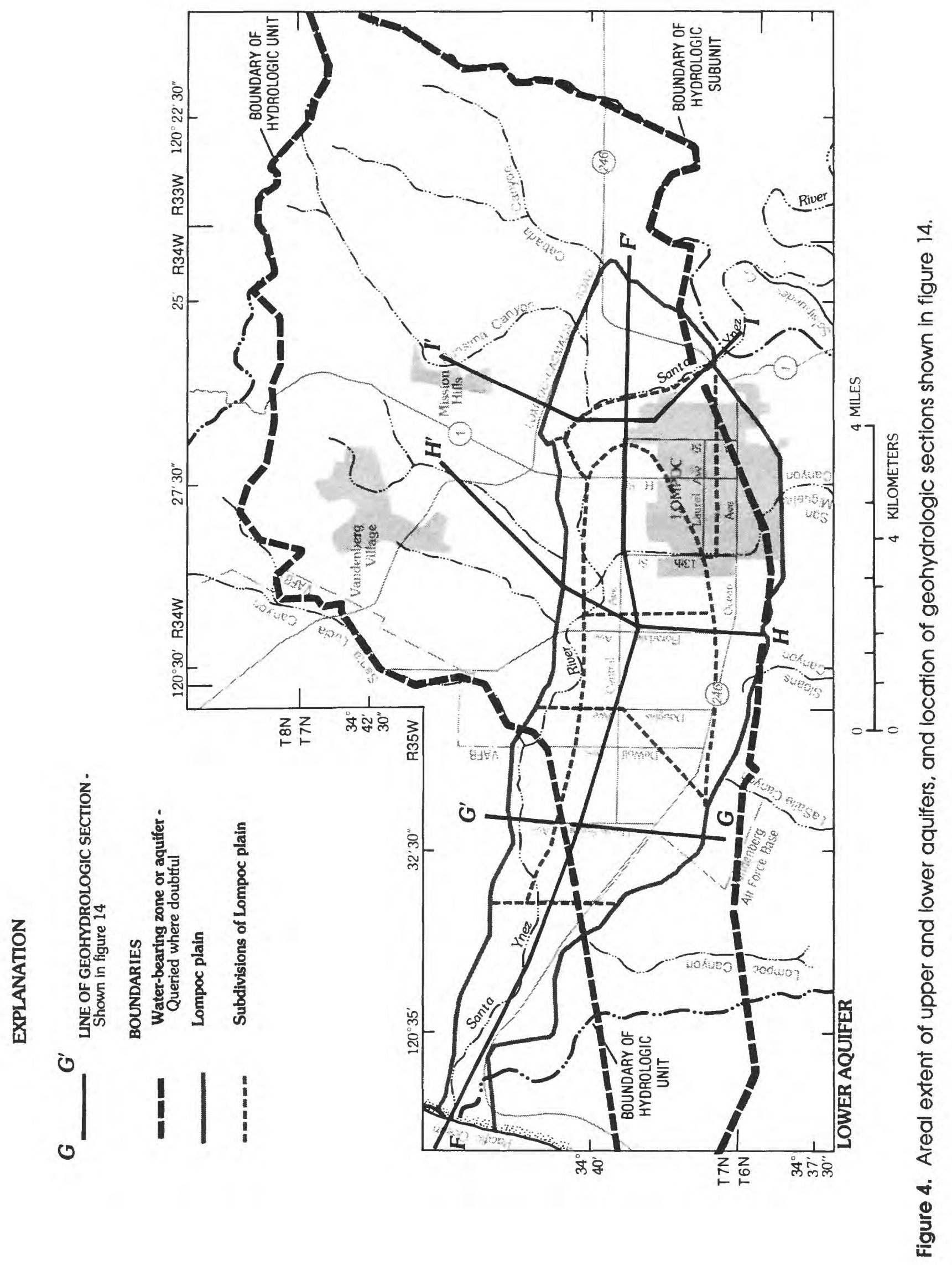


The Careaga Sand consists of two members: the (upper) Graciosa Coarse-Grained Member, which is composed of coarse sand and gravel, and the (lower) Cebada Fine-Grained Member, composed of fine sand. Both members are present beneath the Lompoc upland and most of the Lompoc plain. Beneath the Lompoc terrace, however, the Graciosa Member generally is absent or was unsaturated. Where present, the Graciosa Member of the Careaga Sand was the main producer of ground water in the lower aquifer.

\section{RECHARGE}

The primary sources of recharge to the Lompoc area have included (1) seepage loss from the Santa Ynez River and from streams entering the southern plain and coastal area, (2) infiltration of rainfall, (3) infiltration of excess irrigation water, (4) underflow from river-channel deposits, and (5) infiltration of sewage effluent. The interaction of each recharge and discharge component within the Lompoc area is shown in figure 5 . Estimates of average annual recharge from earlier studies by Upson and Thomasson (1951), Wilson (1959), Evenson (1966), Miller (1976), and Ahlroth and others (1977) are summarized in table 2.

Previous estimates of average annual recharge to the Lompoc area for selected periods (table 2) varied considerably because of different climatic conditions. Precipitation during 1957-62, 1972, and 1975-76 (table 2) was close to the long-term average (1910-87) of $14.6 \mathrm{in} / \mathrm{yr}$ (U.S. Department of Agriculture, 1910-30; U.S. Department of Commerce, 1958, 1954-76; National Oceanic and Atmospheric Administration, 1976-88) and was considered to represent near-normal climatic conditions. Extremely wet conditions existed during 1935-44 when Upson and Thomasson studied the Lompoc area, and extremely dry conditions existed during 1947-51 when Wilson studied the area. Evenson (1966, p. 24) concluded that the increase of estimated average annual recharge during the near-normal period 1957-62 over the earlier wet period (1935-44) was due largely to lower ground-water levels and steeper ground-water gradients than existed during the more recent study. This condition resulted in more available aquifer storage space, which allowed a greater amount of surface and subsurface inflow into the basin. Estimated average annual recharge to the Lompoc area during the dry period 1947-51 (7,600 acre-ft) was less than 30 percent of the average of the estimates for the near-normal periods (26,800 acre-ft).

Estimates of average annual recharge to the Lompoc area differ mainly in the estimated recharge from seepage loss along the Santa Ynez River and streams entering the southem plain, seepage loss of sewage effluent, and irrigation-return flow (table 2). Evenson (1966) estimated that seepage from the Santa Ynez River during 1957-62 averaged about 7,600 acre- $\mathrm{ft}$ annually. This estimate includes 3,000 acre- $\mathrm{ft}$ of seepage loss in the reach from the gaging station at 13th Street to the gaging station at Barrier (fig. 3) (Evenson, 1966, p. 13). The remaining estimates of recharge from this source (for 1935-44, 1972, and 1975-76) were based on seepage losses in a shorter reach along the river from the Narrows to near the gaging station at Pine Canyon (fig. 3). The estimate of 7,600 acre- $\mathrm{ft}$ by Evenson (1966) was therefore adjusted downward in this report (to 4,600 acre-ft) to correspond to the shorter reach used in the other studies.

Recharge estimates of seepage loss from streams entering the southern Lompoc plain for 1935-44, 1947-51, and 1957-62 were based on discharge measurements in Salsipuedes Creek (fig. 1). Upson and Thomasson (1951) accounted for differences in average annual precipitation between Salsipuedes Creek and the streams south of the Lompoc plain by decreasing their estimates of seepage loss by about 30 percent. In this report, estimates of seepage loss from streams entering the southern Lompoc plain by Wilson (1959) and Evenson (1966) were adjusted to correspond to this decrease in precipitation (table 2). Estimates by Miller (1976) and Ahlroth and others (1977) were based on channel-geometry studies on the streams south of the Lompoc plain.

Estimates of recharge from sewage effluent discharged to the Santa Ynez River from the Lompoc Regional Wastewater Treatment Plant were about three times higher for 1972 and 1975-76 than 1957-62 (table 2). This increase in sewage-effluent recharge over the preceding period corresponded to the increase in municipal pumpage by the city of Lompoc beginning in the 1960's (fig. 6).

Estimates of recharge from irrigation-return flow for 1935-44 and 1947-51 (table 2) were considerably lower than estimates for 1957-62, 1972, and 1975-76. 


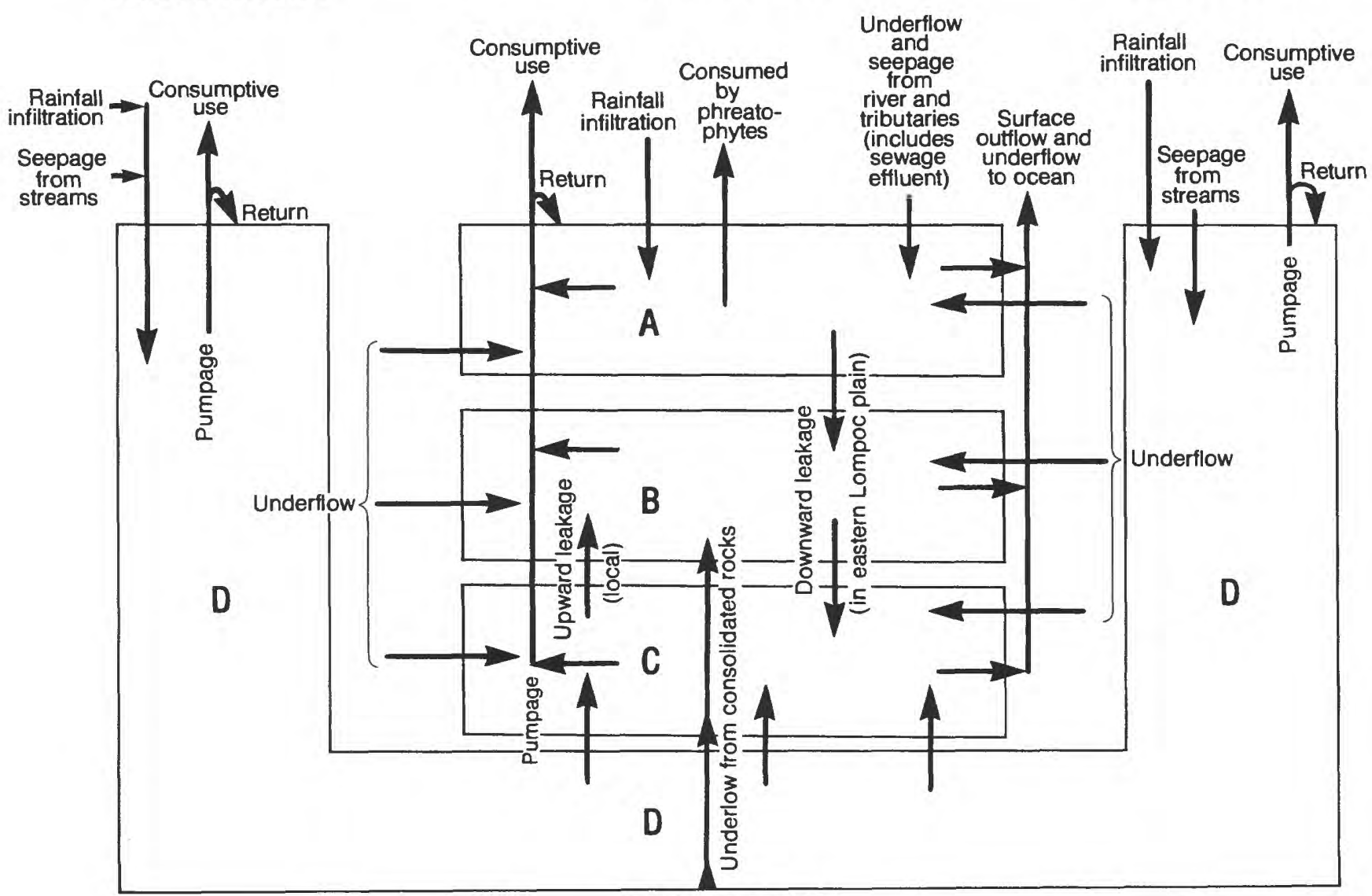

Consolidated rocks

\section{EXPLANATION}

$\begin{array}{ll} & \text { UPPER AQUIFER } \\ \text { A } & \text { Shallow zone } \\ \text { B } & \text { Middle zone } \\ \text { C } & \text { Main zone } \\ \text { D } & \text { LOWER AQUIFER }\end{array}$

Figure 5. Sources of ground-water recharge and discharge in the study area. (Modified from Miller, 1976. fig. 11.)

The increase in estimated return flow for the last three periods reflected an increase in irrigation pumpage (fig. 6) and a decrease in irrigation-efficiency values. Upson and Thomasson (1951) and Wilson (1959) assumed an irrigation-efficiency value of 85 percent (that is, about 15 percent of the applied irrigation water returned to the water table). Evenson (1966) and Ahlroth and others (1977) based their estimates of recharge on lower irrigation-efficiency values; they assumed that about 45 and 44 percent, respectively, of the applied irrigation water returned to the water table. Recharge from irrigation-retum flow in 1972 was not estimated by Miller (1976). In order to obtain an estimate of average annual recharge in 
Table 2. Estimates of average annual recharge in the Lompoc area for selected periods

[Recharge values are in acre-foot. in., inch; --, no data]

\begin{tabular}{|c|c|c|c|c|c|}
\hline Recharge source & $\begin{array}{c}1935-44 \\
\text { (Upson and } \\
\text { Thomasson, } \\
1951 \text { ) }\end{array}$ & $\begin{array}{c}1947-51 \\
\text { (Wilson, 1959) }\end{array}$ & $\begin{array}{c}1957-62 \\
\text { (Evenson, } \\
1966)\end{array}$ & $\begin{array}{c}1972 \\
\text { (Miller, 1976) }\end{array}$ & $\begin{array}{c}1975-76 \\
\text { (Ahlroth and } \\
\text { others, } \\
1977 \text { ) }\end{array}$ \\
\hline
\end{tabular}

Seepage loss

\begin{tabular}{|c|c|c|c|c|c|}
\hline Along the Santa Ynez River . . . . . . & 2,500 & 500 & $\begin{array}{r}7,600 \\
14,600\end{array}$ & 3,000 & 4,000 \\
\hline $\begin{array}{l}\text { Sewage effluent discharged } \\
\text { to Santa Ynez River .... }\end{array}$ & 0 & 800 & 700 & 22,300 & 2,000 \\
\hline $\begin{array}{l}\text { Streams entering the southern } \\
\text { plain and coastal area. }\end{array}$ & 5,400 & $\begin{array}{r}700 \\
1_{500}\end{array}$ & $\begin{array}{r}7,000 \\
15,000\end{array}$ & 1,200 & 3,600 \\
\hline $\begin{array}{l}\text { Rainfall infiltration } \\
\text { Lompoc plain } \ldots \ldots \ldots \ldots \ldots \ldots \\
\text { Lompoc upland } \ldots \ldots \ldots \ldots \ldots\end{array}$ & $\begin{array}{r}4,800 \\
4,600\end{array}$ & $\begin{array}{r}0 \\
900\end{array}$ & $\begin{array}{l}3,500 \\
2,600\end{array}$ & $\begin{array}{l}4,000 \\
2,600\end{array}$ & $\begin{array}{l}4,600 \\
2,000\end{array}$ \\
\hline $\begin{array}{l}\text { Underflow from river-channel deposits } \\
\text { Santa Ynez River at the Narrows ... } \\
\text { Southern Lompoc plain . . . . . . . }\end{array}$ & $\begin{array}{r}600 \\
--\end{array}$ & $\begin{array}{r}1,500 \\
--\end{array}$ & $\begin{aligned} 1,500 \\
--\end{aligned}$ & 200 & $\begin{array}{l}1,700 \\
1,700\end{array}$ \\
\hline Irrigation-return flow . . & 1,500 & 3,200 & 9,700 & 57,200 & ${ }^{6} 7,800$ \\
\hline Average annual recharge $\ldots \ldots \ldots$ & 19,400 & 7,600 & 32,600 & 20,500 & 27,400 \\
\hline
\end{tabular}

Average annual precipitation

during indicated period (in.) ......

19.3

7.9

13.5

${ }^{7} 12.5$

${ }^{8} 14.3$

${ }^{1}$ Modified recharge estimates for this report. These values are not included in the calculation of average annual recharge.

${ }_{2}^{2}$ Equals total amount of wastewater effluent discharged to the Santa Ynez River.

${ }^{3}$ Does not include estimates of recharge from streams entering the northern Lompoc plain (for example, Purisima and Cebada Canyons).

${ }^{4}$ Calculated for this report using infiltration estimates supplied by Santa Barbara County Water Agency.

${ }^{5}$ Calculated for this report. This value is included in the calculation of average annual recharge.

${ }^{6}$ Equals difference between applied irrigation water and agricultural consumptive use (Ahlroth and others, 1977).

${ }^{7}$ Average annual precipitation for 1968-72 (U.S. Department of Commerce, Weather Bureau, 1954-76).

${ }^{8}$ Average annual precipitation for 1972-76 (U.S. Department of Commerce, Weather Bureau, 1954-76; National Oceanic and Atmospheric Administration, 1976-88).

1972, recharge from irrigation-return flow for that period was calculated by multiplying a return-flow value of 44 percent (Miller, 1976, p. 32) by the value of irrigation pumpage for 1972 (16,200 acre-ft; fig. 6). This calculation gives a value of about 7,200 acre-ft (table 2).
Ground-water recharge from the Santa Ynez River has occurred primarily along the reach from the Narrows to H Street (fig. 3). A lesser, but significant quantity of recharge also has occurred from $\mathrm{H}$ Street to at least the gaging station at Pine Canyon (Miller, 1976), and possibly as far west as Union Sugar 


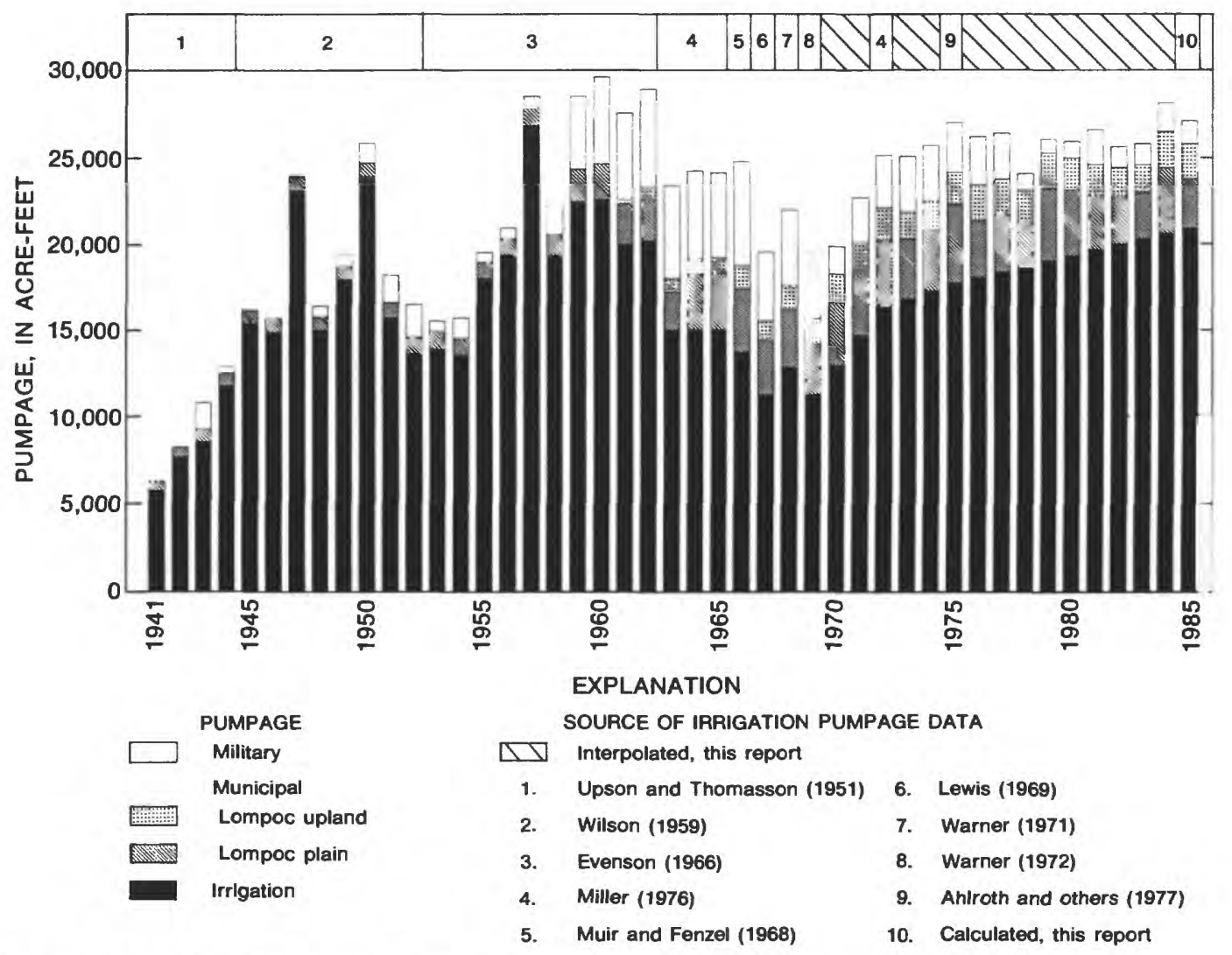

Figure 6. Components of annual pumpage in the Lompoc area, 1941-85.

Avenue (fig. 3). Streamflow has been maintained west of the Lompoc Regional Wastewater Treatment Plant (LRWTP) by sewage effluent that has been discharged continuously (fig. 3) since 1916 (Gary Keefe, city of Lompoc, oral commun., 1990). Successive measurements of streamflow were made along the reach from LRWTP to about 2.6 mi downstream on June 16, 1988. Streamflow measurements and losses are presented in table 3. All losses in streamflow were considered to be the result of seepage loss. The measurements indicate that the rate of seepage loss decreased with increased distance downstream from LRWTP. The annual recharge contributed by seepage loss over this reach was estimated by multiplying the total loss of streamflow (14.78 acre-ft/d) by the average number of days of streamflow per year (365); which gives a value of about $5,400 \mathrm{acre}-\mathrm{ft} / \mathrm{yr}$. This method of estimating the annual recharge rate has two main deficiencies: (1) loss of streamflow due to evapotranspiration is not accounted for, and (2) the variation in seepage-loss rate caused by changes in the amount of streamflow is neglected. The presence of lush vegetation downgradient of LRWTP in 1988 suggests that at least some of the sewage effluent was evapotranspired. Consequently, the estimate of annual recharge given above should be considered a maximum estimate; the actual value probably was considerably less.

The regimen of flow in the Santa Ynez River has been altered in the Lompoc area since the completion of Bradbury Dam (fig. 1) on the river in 1953. The dam, which created Lake Cachuma, is about $30 \mathrm{mi}$ upstream from the Lompoc plain. Bradbury Dam was designed to divert nearly 30,000 acre-ft of water from the Santa Ynez River drainage basin to the Santa Barbara coastal area (Miller, 1976, p. 17). The relative duration of measured streamflow for the gaging stations at the Narrows and at Robinson Bridge (site 2) (fig. 3) for periods before (November 1, 1906 to January 1, 1953) and after (January 1, 1953 to September 30,1987) the construction of Bradbury Dam is shown in figure 7. Historical discharge records at the Narrows and Robinson Bridge were 
Table 3. Measurements of streamflow and sewage effluent along the Santa Ynez River in the Lompoc area, June 16, 1988

[Streamflow: Controlled release of sewage effluent from city of Lompoc Regional Wastewater Treatment Plant to Santa Ynez River on June 16, 1988. $\mathrm{ft}^{3} / \mathrm{s}$, cubic foot per second; acre-ft/d, acre-foot per day; mi, mile; (acre-ft/d)/mi, acre-foot per day per mile; ft, foot. na, not applicable]

\begin{tabular}{|c|c|c|c|c|c|}
\hline \multirow{2}{*}{ Streamflow measurement site } & \multicolumn{2}{|c|}{ Streamflow } & \multirow{2}{*}{$\begin{array}{l}\text { Loss of } \\
\text { streamflow } \\
\text { between } \\
\text { stations } \\
\text { (acre-ft/d) }\end{array}$} & \multirow{2}{*}{$\begin{array}{l}\text { Flow } \\
\text { distance } \\
\text { between } \\
\text { stations } \\
\text { (mi) }\end{array}$} & \multirow{2}{*}{$\begin{array}{l}\text { Rate of loss } \\
\text { of streamflow } \\
\text { between } \\
\text { stations } \\
{[(\text { acre-ft/d)/mi }]}\end{array}$} \\
\hline & $\left(\mathrm{ft}^{3} / \mathrm{s}\right)$ & (acre-ft/d) & & & \\
\hline \multicolumn{6}{|l|}{ Outflow drain at Lompoc Regional } \\
\hline Wastewater Treatment Plant ...... & 9.09 & 18.03 & na & na & na \\
\hline $1,200 \mathrm{ft}$ east of Floradale Avenue $\ldots$. & 7.36 & 14.60 & 3.43 & 0.45 & 7.62 \\
\hline Floradale Avenue $\ldots \ldots \ldots \ldots \ldots$ & 5.82 & 11.54 & 3.06 & .47 & 6.51 \\
\hline $600 \mathrm{ft}$ east of De Wolf Avenue ..... & 1.64 & 3.25 & 8.29 & 1.69 & 4.91 \\
\hline Total & & & 14.78 & 2.61 & ${ }^{1} 5.66$ \\
\hline
\end{tabular}

${ }^{1}$ Equals total loss of streamflow between stations divided by total flow distance between stations.



Figure 7. Flow-duration curves for the Santa Ynez River in the Lompoc area (based on gaging-station records at the Narrows and at Robinson Bridge).

combined in order to extend the period of record of the flow-duration curves. Figure 7 shows that streamflow in the Santa Ynez River has diminished in the Lompoc area since the completion of Bradbury Dam, especially at lower flows. For example, a measured discharge of $10 \mathrm{ft}^{3} / \mathrm{s}$ or 7,240 acre- $\mathrm{ft} / \mathrm{yr}$ was equaled or exceeded 58 percent of the time prior to the construction of Bradbury Dam. After the construction of the dam, a streamflow of $10 \mathrm{ft}^{3} / \mathrm{s}$ was equaled or exceeded 30 percent of the time. 


\section{DISCHARGE}

The primary components of ground-water discharge from the aquifers in the Lompoc area include (1) agricultural, municipal, and military pumpage, (2) transpiration by phreatophytes along the Santa Ynez River, (3) underflow from the upper aquifer to the ocean, and (4) seepage to the Santa Ynez River in the coastal area. Table 4 summarizes estimates of discharge from earlier studies.

The main component of ground-water discharge in the Lompoc area has been ground-water pumpage. Ground water has been used primarily for irrigation, municipal, and military purposes. The annual distribution of the various pumpages from the groundwater basin for 1941-85 is shown graphically in figure 6 . Ground-water pumpage reached a maximum of 29,600 acre- $\mathrm{ft} / \mathrm{yr}$ in 1960 and has remained relatively constant since that time, except for a slight decrease in the middle and late 1960's. Most irrigation-pumpage estimates were compiled from the reports listed in figure 6. Irrigation pumpage was estimated for 1985 using a consumptive-use factor for each irrigated crop (Ahlroth and others, 1977; California Department of Water Resources, 1987). Municipal and military pumpages values were for metered wells. Lompoc plain municipal-pumpage values were for the city of Lompoc. Lompoc upland municipal-pumpage values were for Park Water
Company (1961-85) and Mission Hills Community Service District (1975-85). For years in which pumpage data are lacking, estimates were made by interpolating between calculated values.

Most of the ground-water pumpage in the Lompoc area historically has been used for irrigation (fig. 6). Irrigation wells have been located throughout the Lompoc plain, with the exception of the area occupied by the city of Lompoc. Figure 6 also shows that municipal and military pumpages increased significantly in the late 1950 's and early 1960 's. Although municipal pumpage has remained relatively constant since the 1960 's, military pumpage in the Lompoc area has decreased in recent years as a result of increased percentage of pumping by VAFB from San Antonio Creek valley north of the Santa Ynez River drainage.

Estimates of transpiration by phreatophytes along the Santa Ynez River are given in table 4. Upson and Thomasson (1951) also included transpiration by phreatophytes in the western plain and evaporation from the Santa Ynez River and from bare areas in the channel. The transpiration estimate of 3,200 acre-ft by Miller (1976) was based on periodic surveys of phreatophytes along the Santa Ynez River by the U.S. Bureau of Reclamation (1964-75). These studies concluded that transpiration by phreatophytes along the river ranged from approximately 2,800 to 3,200 acre-ft/yr for 1962-73.

Table 4. Estimates of average annual discharge in the Lompoc area for selected periods

[Discharge values are in acre-feet. --, no data]

\begin{tabular}{|c|c|c|c|c|c|}
\hline Discharge source & $\begin{array}{c}1935-44 \\
\text { (Upson and } \\
\text { Thomasson, } \\
\text { 1951) }\end{array}$ & $\begin{array}{c}1947-51 \\
\text { (Wilson, 1959) }\end{array}$ & $\begin{array}{c}\text { 1957-62 } \\
\text { (Evenson, } \\
1966)\end{array}$ & $\begin{array}{c}1972 \\
\text { (Miller, 1976) }\end{array}$ & $\begin{array}{c}1975-76 \\
\text { (Ahlroth and } \\
\text { others, } \\
1977)\end{array}$ \\
\hline Ground-water pumpage $\ldots \ldots \ldots \ldots$ & ${ }^{1} 10,000$ & ${ }^{1} 21,400$ & ${ }^{2} 27,400$ & 225,000 & ${ }^{2} 26,000$ \\
\hline Transpiration by phreatophytes ..... & 5,100 & 3,000 & 6,000 & ${ }^{3} 3,200$ & 3,200 \\
\hline Underflow to ocean $\ldots \ldots \ldots \ldots$ & 400 & 300 & 150 & 150 & 250 \\
\hline Seepage to the Santa Ynez River .... & 1,500 & 100 & -- & 100 & - \\
\hline Average annual total discharge .. & 17,000 & 24,800 & 33,550 & 28,450 & 29,450 \\
\hline
\end{tabular}

${ }^{1}$ Pumpage for Lompoc plain only.

${ }^{2}$ Pumpage for Lompoc plain, terrace, and upland (Mission Hills not included).

${ }^{3}$ Estimate based on vegetation data for 1964-75. 


\section{GROUND-WATER LEVELS AND MOVEMENT}

Ground-water levels in the Lompoc area during 1987-88 were determined from measurements of static water levels in 63 monitor wells (table 5). Many of the water-level measurements were made by the U.S. Geological Survey at selected sites in the Lompoc plain. Additional water-level measurements were collected from monitor-well networks operated by the U.S. Bureau of Reclamation, by Santa Barbara County, and by the city of Lompoc. At most sites, nest of wells were perforated at different depths to enable the determination of the vertical distribution of hydraulic head. Those sites are referred to in this report as cluster sites. The location of the monitor wells and cluster sites is shown in figure 8 . Well-construction data for all monitor wells and cluster sites are given in table 7 (at back of report).

Water-level measurements made during this study indicate that hydraulic head varied significantly with depth in the Lompoc plain. Figure 9 shows potentiometric contours for the shallow and main zones of the upper aquifer and for the lower aquifer. These contours were based on summer 1987 and spring 1988 water-level measurements. Potentiometric contours for the middle zone of the upper aquifer are not included in figure 9 because of insufficient data.

Ground-water movement in the shallow and main zones of the upper aquifer in spring 1988 generally was from east to west. In the eastern plain, ground water moved freely between zones in the upper aquifer, and flow directions in the main and shallow zones were similar. In both zones, ground water moved westward from the Santa Ynez River toward a water-level depression around the municipal supply wells for the city of Lompoc. These wells obtained most of their water from the main zone. Thus, much of the ground water that recharged the upper aquifer in the eastern plain, from seepage along the Santa Ynez River and underflow through river-channel deposits at the Narrows, was intercepted by these municipal supply wells. In 1975-76, average annual pumpage for the city of Lompoc (fig. 6) was approximately 70 percent of the estimated annual recharge from these sources (table 2).
In the central plain, ground-water movement in the shallow and main zones was slightly different. Ground-water movement in the shallow zone during spring 1988 generally was northwestward. Groundwater movement in the main zone during this period generally was westward. The northwestward movement of ground water in the shallow zone in this area probably was caused by recharge along La Salle and Sloans Canyons at the edge of the southern plain (fig. 9). The southern plain has been described in earlier studies as having free interchange of water between the shallow and middle zones of the upper aquifer and the lower aquifer (Upson and Thomasson, 1951, p. 135). In the central plain, however, silt and clay deposits underlying the middle zone limited downward movement of ground water to the main zone.

In the northern parts of the central plain and western plain, ground-water movement through the shallow zone generally was toward the west and parallel with the Santa Ynez River during spring 1988. In this area, flow in the river was maintained primarily by sewage effluent discharged from the Lompoc Regional Wastewater Treatment Plant. Although streamflow data for summer 1988 (table 3) indicate that seepage of water from the river has occurred downgradient of the LRWTP, water levels and dissolved-solids concentrations in the shallow zone suggest that recharge from the river did not move toward the south and into the shallow zone. Silt and clay deposits in the shallow and middle zones are present to the south and beneath the river in this area, respectively. These deposits probably restrict seepage of water from the river to the permeable channel deposits adjacent to the main course of the river. However, water levels and dissolved-solids concentrations in the shallow and main zones of the northwestern plain indicate that recharge from the river moved freely from the shallow zone and into the main zone (fig. 9). This area has been described in earlier studies as having free interchange of water between all zones in the upper aquifer (Upson and Thomasson, 1951, p. 146). 
Table 5. Static water levels for selected monitor wells, summer 1987 and spring 1988

[Static water levels correspond to potentiometric contours in figure 9. Measured zone or aquifer was determined on the basis of well perforations and water quality. State well No.: See well-numbering system in text. Altitude of water level is in feet above sea level. Monitoring agency: COL, city of Lompoc; SB, Santa Barbara County; USBR, U.S. Bureau of Reclamation; USGS, U.S. Geological Survey. --, no data]

\begin{tabular}{cccl}
\hline $\begin{array}{c}\text { State } \\
\text { well No. }\end{array}$ & Date & $\begin{array}{c}\text { Altitude of } \\
\text { water level }\end{array}$ & $\begin{array}{c}\text { Monitoring } \\
\text { agency }\end{array}$ \\
\hline \multicolumn{5}{c}{ Upper Aquifer--Shallow Zone } \\
\hline 7N/34W- 22L2 & $3-28-88$ & 57.8 & USBR \\
27K4 & $4-11-88$ & 49.41 & USGS \\
27P6 & $4-14-88$ & 37.19 & USGS \\
29F2 & $4-13-88$ & 36.54 & USGS \\
29N4 & $4-12-88$ & 39.44 & USGS \\
30L3 & $3-24-88$ & 35.38 & SB \\
31C3 & $3-24-88$ & 44.28 & SB \\
33E5 & $4-12-88$ & 44.08 & USGS \\
35F2 1 & $3-23-88$ & 82.78 & SB \\
& & & \\
$7 N / 35 W-13 N 2$ & $4-15-88$ & 36.27 & USGS \\
17Q6 & $5-02-88$ & 10.33 & USGS \\
23B2 & $4-15-88$ & 11.58 & USGS \\
23Q2 & $4-12-88$ & 23.90 & COL \\
25F7 & $3-24-88$ & 34.61 & SB \\
26L1 & $4-12-88$ & 30.09 & USGS \\
& & &
\end{tabular}

\begin{tabular}{cccl}
\hline \multicolumn{5}{c}{ Upper Aquifer--Main Zone } \\
\hline 7N/34W- 27K7 & $4-12-88$ & 50.08 & COL \\
27N5 & $3--88$ & 38.36 & COL \\
27P5 & $3--88$ & 39.86 & COL \\
27Q2 & $3--88$ & 43.67 & COL \\
28M2 & $4-14-88$ & 42.12 & COL \\
29F1 & $4-13-88$ & 33.24 & COL \\
29N6 & $4-12-88$ & 31.41 & COL \\
34A4 & $3--88$ & 56.00 & COL \\
34B1 & $3--88$ & 44.23 & COL \\
34F6 & $3--88$ & 45.89 & COL \\
35K9 & $3-23-88$ & 79.23 & SB \\
& & & \\
7N/35W- 17K21 & $4-12-88$ & 6.67 & COL \\
17M1 & $3-24-88$ & 6.44 & SB \\
21G2 & $5-02-88$ & 8.59 & USGS \\
22J1 & $3-24-88$ & 13.53 & SB \\
23E2 & $4-03-88$ & 18.72 & SB \\
23Q4 & $4-13-88$ & 16.32 & USGS \\
24J4 & $3-24-88$ & 20.40 & SB \\
24K5 & $3-25-88$ & 27.03 & SB \\
25F5 & $3-24-88$ & 18.61 & SB \\
26F4 & $4-03-88$ & 14.95 & SB
\end{tabular}

\begin{tabular}{|c|c|c|c|}
\hline $\begin{array}{c}\text { State } \\
\text { well No. }\end{array}$ & Date & $\begin{array}{l}\text { Altitude of } \\
\text { water level }\end{array}$ & $\begin{array}{c}\text { Monitoring } \\
\text { agency }\end{array}$ \\
\hline \multicolumn{4}{|c|}{ Lower Aquifer } \\
\hline $6 \mathrm{~N} / 34 \mathrm{~W}-4 \mathrm{G} 4$ & $3-28-88$ & 44.9 & SB \\
\hline $6 \mathrm{Cl}$ & $3-24-88$ & 36.15 & SB \\
\hline $7 N / 33 W-16 G 2$ & $8-06-87$ & 152.67 & USGS \\
\hline $17 \mathrm{M} 1$ & $8-06-87$ & 94.15 & USGS \\
\hline 19D1 & $3-23-88$ & 75.02 & SB \\
\hline $20 \mathrm{G} 3$ & $8-04-87$ & 81.85 & USGS \\
\hline $21 \mathrm{G} 2$ & $8-04-87$ & 119.91 & USGS \\
\hline $28 \mathrm{D} 1$ & $8-06-87$ & 77.50 & USGS \\
\hline 28D3 & $3-23-88$ & 73.52 & SB \\
\hline $7 \mathrm{~N} / 34 \mathrm{~W}-9 \mathrm{H} 5$ & $3-25-88$ & 24.14 & SB \\
\hline $12 \mathrm{E} 1$ & $3-24-88$ & 64.87 & SB \\
\hline $14 \mathrm{~F} 3$ & $3-24-88$ & 51.53 & SB \\
\hline $14 \mathrm{~L} 1$ & $3-24-88$ & 41.20 & SB \\
\hline $15 \mathrm{D} 1$ & $3-25-88$ & 49.00 & SB \\
\hline $15 \mathrm{P} 1$ & $3-24-88$ & 52.22 & SB \\
\hline $20 \mathrm{P} 3$ & $11-06-87$ & 343.06 & USGS \\
\hline $22 J 6$ & $3-22-88$ & 255.52 & SB \\
\hline $24 \mathrm{~N} 1$ & $3-22-88$ & 58.07 & SB \\
\hline $26 \mathrm{H} 3$ & $3-23-88$ & 257.22 & SB \\
\hline $26 \mathrm{Q} 5$ & $3-28-88$ & 52.8 & USBR \\
\hline $27 \mathrm{~K} 6$ & $4-12-88$ & 50.73 & $\mathrm{COL}$ \\
\hline $29 N 7$ & $4-12-88$ & 32.64 & USGS \\
\hline $7 N / 35 W-26 L 4$ & $4-12-88$ & 18.08 & USGS \\
\hline $27 \mathrm{P} 1$ & $5-02-88$ & 34.16 & USGS \\
\hline $31 \mathrm{~J} 1$ & $5-02-88$ & 108.65 & USGS \\
\hline $33 \mathrm{~J} 2$ & -- & ${ }^{4} 43$ & USGS \\
\hline $33 \mathrm{~J} 3$ & $5-02-88$ & 86.78 & USGS \\
\hline
\end{tabular}

\footnotetext{
${ }^{1}$ Upper perforations in river-channel deposits. Aquifer opposite lower perforations uncertain.

${ }^{2}$ Water level questionable due to unknown perforated interval.

${ }^{3}$ Water level questionable due to date of measurement.

${ }^{4}$ Average static water-level altitude, May 1983November 1987.
} 


\section{EXPLANATION}

BOUNDARY OF LOMPOC PLAIN

SUBDIVISION BOUNDARIES OF LOMPOC PLAIN

O 17M1 WATER-LEVEL MONITORING WELL AND NUMBER

17G1 WATER-QUALTY MONITORING WELL AND NUMBER

17K21 WATER-LEVEL AND WATER-QUALTY MONITORING WELL
AND NUMBER $\phi^{23 Q 1}$ WATER-LEVEL AND WATER-QUALTYY MONITORING CLUSTER STIE


Figure 8. Location of monitor wells and cluster sites.

22 Ground-Water Hydrology and Quality, Lompoc Area, Santa Barbara County, California 


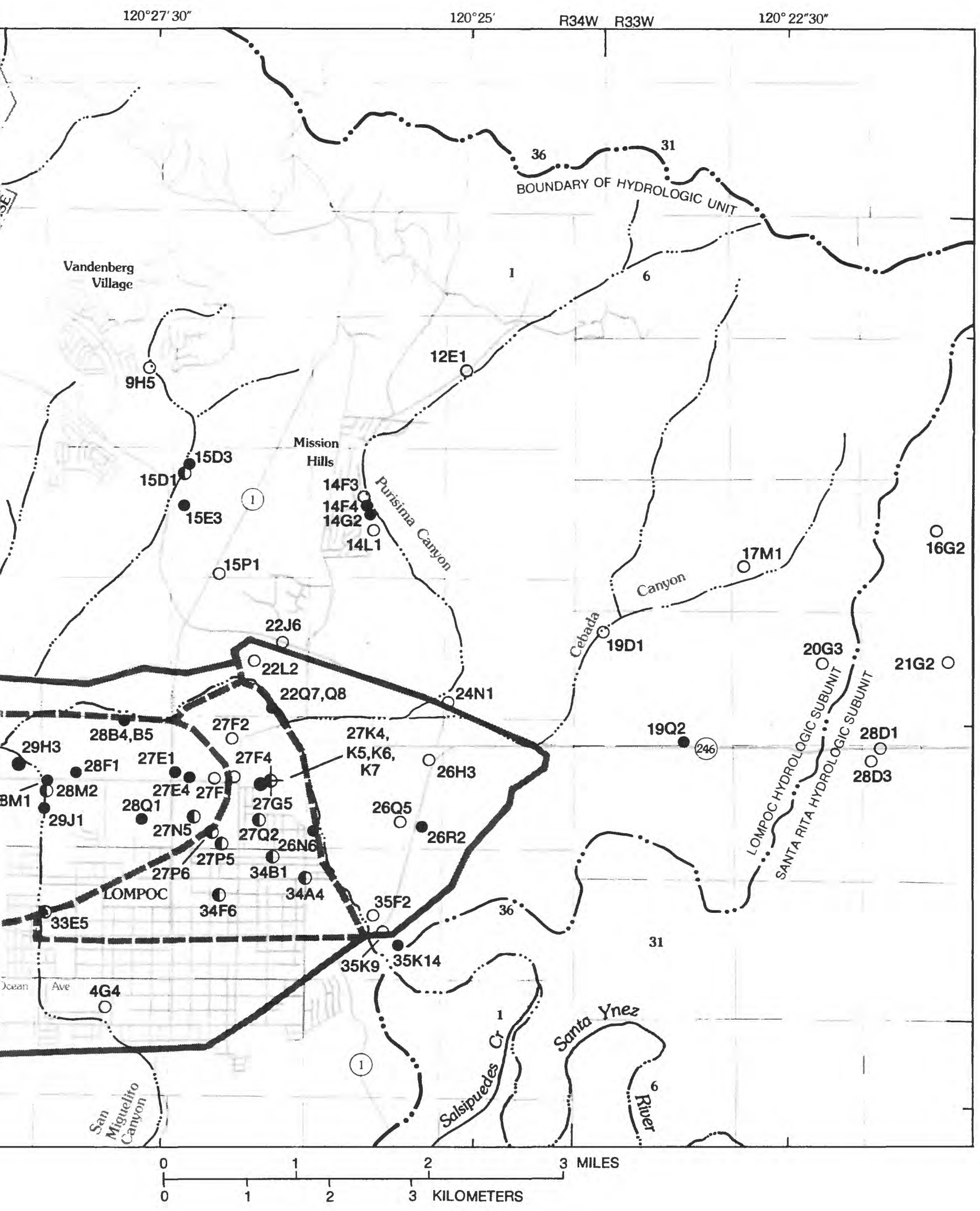



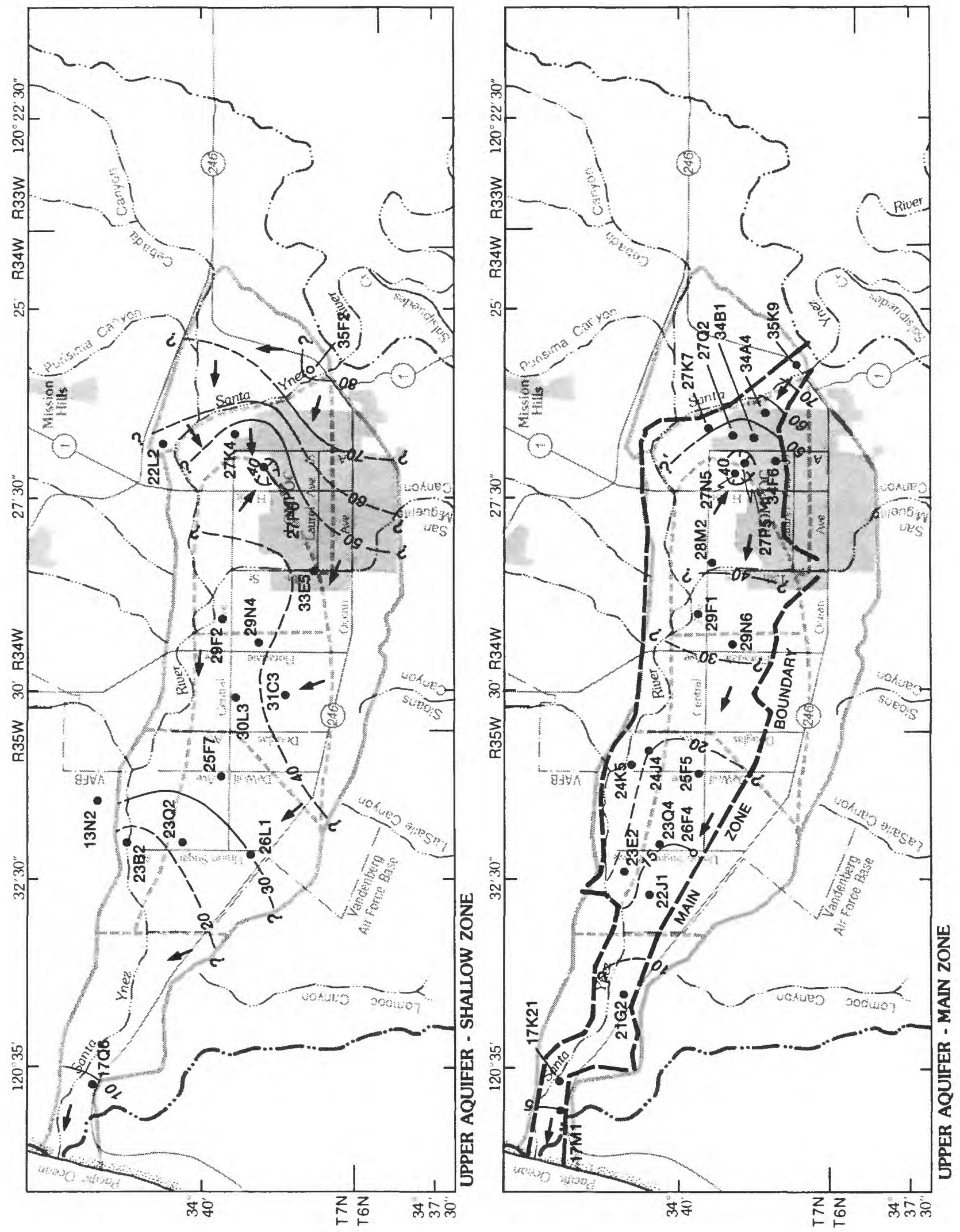


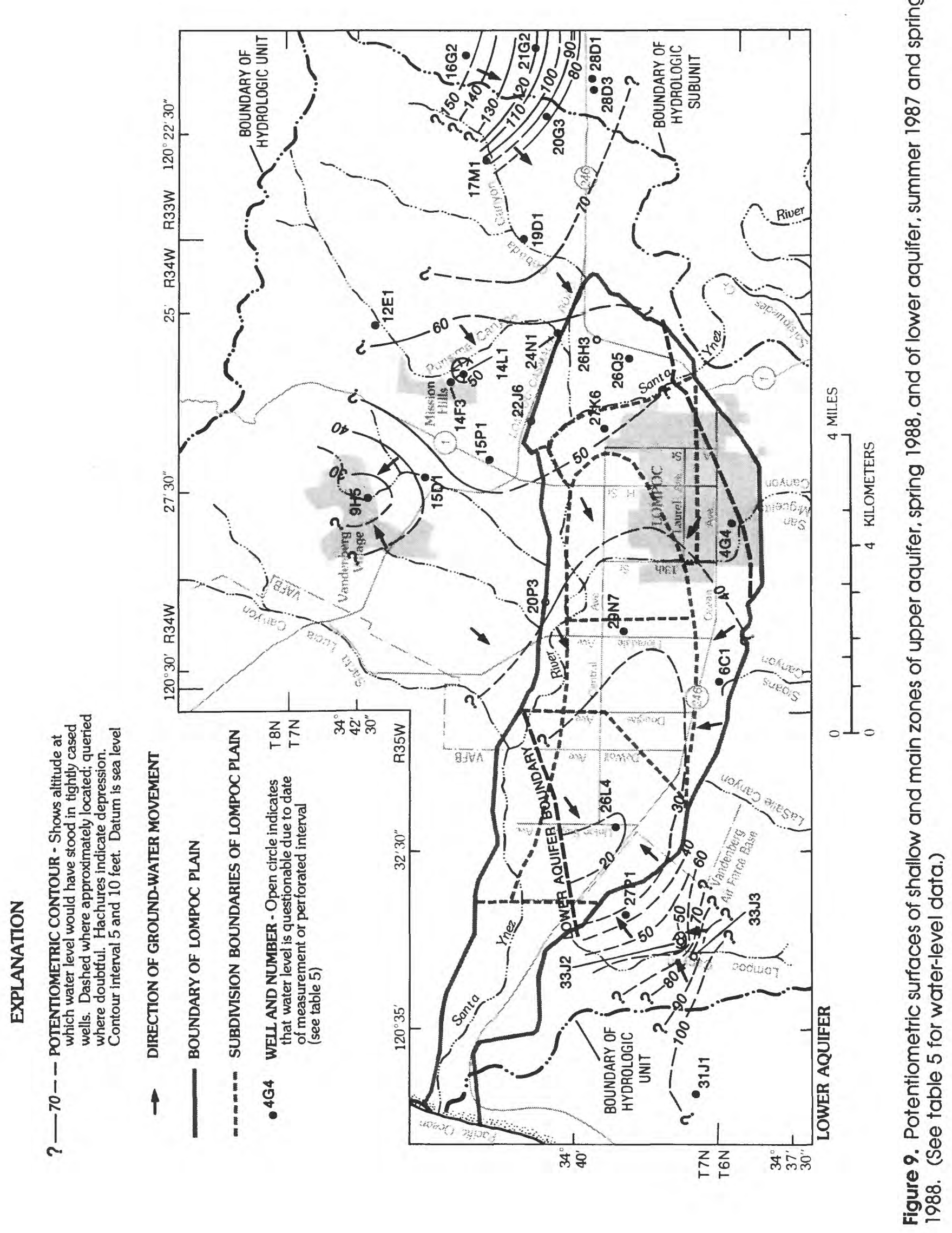


During spring 1988, ground water moved from the Lompoc upland and terrace areas toward the Lompoc plain through the lower aquifer. Most of the water-level measurements in the lower aquifer were made in spring 1988; however, water-level measurements along the eastern boundary of the Lompoc area were made in August 1987. In the Lompoc upland, the 1988 water-level measurements indicate two distinct cones of depression caused by municipal pumping. One of the depressions was in Vandenberg Village, and the other was in Mission Hills. The depression in Mission Hills was centered around two municipal supply wells. A municipal well in the center of the depression in Vandenberg Village has supplied only a small percentage of the total annual pumpage since 1979. Long-term hydrographs (see fig. 11C) confirm that the altitude of the potentiometric surface of the lower aquifer declined in this area during 1958-88. Comparison of a water-level contour map prepared by Miller $(1976$, p. 25$)$ with the map presented in this report for 1988 data (fig. 9) indicates that the contours are almost identical near Vandenberg Village. This depression reflects a longterm condition that may be the result of ground-water pumping at the golf course located at the northern edge of Vandenberg Village.

East of Cebada Canyon in the eastern part of the study area, ground water in the lower aquifer generally moved southwestward during August 1987. This movement approximately paralleled the eastern surface-water divide of the basin. Consequently, this surface-drainage divide also acted as a ground-water divide, and it defined the eastern extent of the ground-water basin.

Ground-water movement in the lower aquifer was generally northeastward in spring 1988 in the Lompoc terrace. Water-level measurements indicate a relatively small depression caused by pumping in Lompoc Canyon.

In the lower aquifer, ground water that was not intercepted by production wells in the Lompoc upland and terrace areas flowed toward the western plain. A subsurface ridge of consolidated rocks forms the boundary of the lower aquifer beneath the plain in this area (fig. 9). This ridge creates a ground-water barrier that forced ground water from the lower aquifer to flow into the overlying middle and main zones of the upper aquifer.

Hydraulic head in the lower aquifer was higher than head in the main zone of the upper aquifer in all areas during spring 1988. Thus, water flowed from the lower aquifer to the main zone.

\section{SEASONAL CHANGES}

Cluster sites were constructed in four selected agricultural fields in the Lompoc plain to monitor seasonal changes in water levels. The location of the sites is shown in figure 8 . One site was adjacent to an irrigated field in the eastern plain. This field was naturally drained and was in an area where the upper aquifer received recharge from the Santa Ynez River (Miller, 1976). Two additional sites, also naturally drained, were in irrigated fields in the central plain and in the northern part of the western plain. A fourth site was located adjacent to an irrigated field in the southern part of the western plain; this site was artificially drained by an unlined canal. At each of the sites, three or more monitor wells were installed at different depths, and bimonthly water-level measurements were made in 1987 . Weekly water-level measurements were made in 1988 at all sites, except the southern site in the western Lompoc plain. Continuous water-level recorders were installed in one well at both the central plain site and the northern site in the western plain (table 8 , at back of report). Water levels during 1987-88 at each of the sites are shown in figure 10.

In the eastern plain, hydrographs (fig. 10A) for the cluster wells indicate similar water-level fluctuations in the shallow, middle, and main zones of the upper aquifer, which suggest that ground water moved freely between the zones, as described by Upson and Thomasson (1951). In addition, hydrographs at this site indicate that water-level fluctuations in the lower aquifer generally were similar to fluctuations in the upper aquifer during 1988 (fig. 10A). Water-level altitudes in the well tapping the main zone were consistently lower than in the wells tapping the shallow and middle zones and in the well tapping the underlying lower aquifer. Therefore, the main zone received leakage from both overlying and underlying water-bearing deposits.

Water levels in wells at the cluster site in the central plain (fig. 10B) varied seasonally during 1987-88. During the irrigation season, about April through September, water levels in wells tapping the middle and main zones of the upper aquifer and in the lower aquifer declined significantly. Most of the irrigation wells in the Lompoc plain were perforated in both the middle and main zones. During 1988, pumpage from the lower aquifer beneath the Lompoc plain was limited to VAFB and U.S. Penitentiary (USP) supply wells in the northern plain (fig. 1). The water-level fluctuations in wells tapping the lower aquifer at the central plain site were similar to 

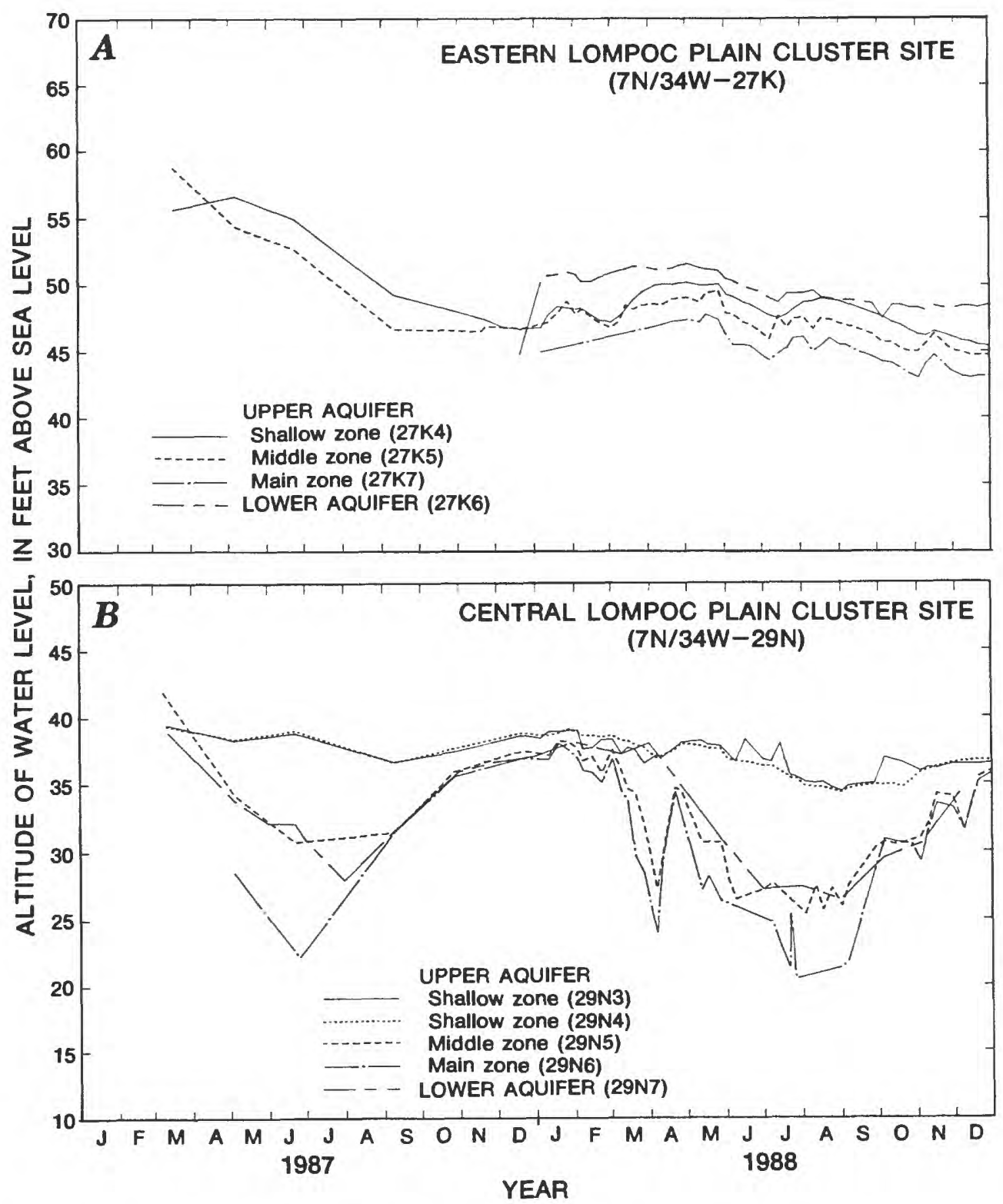

Figure 10. Altitude of water levels for selected cluster sites, 1987-88.

the seasonal water-level changes in both the middle and main zones. Water-level declines in the well perforated in the lower aquifer at this site probably were caused by a combination of seasonal irrigation pumpage from the main zone and pumping by VAFB and USP from the lower aquifer to the north. Waterlevel data in the central plain indicate that hydraulic head in the lower aquifer was higher than in the main zone during the irrigation seasons of 1987-88.

In the central plain, water levels in wells perforated in the shallow zone did not fluctuate significantly during the irrigation season, and the fluctuations were not similar to water-level changes in wells perforated in underlying zones. Slight increases in hydraulic head in the shallow zone probably were due to infiltration of irrigation water. The large hydraulic-head differences that occurred between the shallow zone and underlying zones during the irrigation season are due, in part, to thick deposits of silt and clay in the shallow zone. Downward leakage of ground water from the shallow zone to the middle zone was limited by these fine deposits. During the non-irrigation season, October through March, water-level altitudes in all wells tapping the upper and lower aquifers were nearly equal in the central plain. 

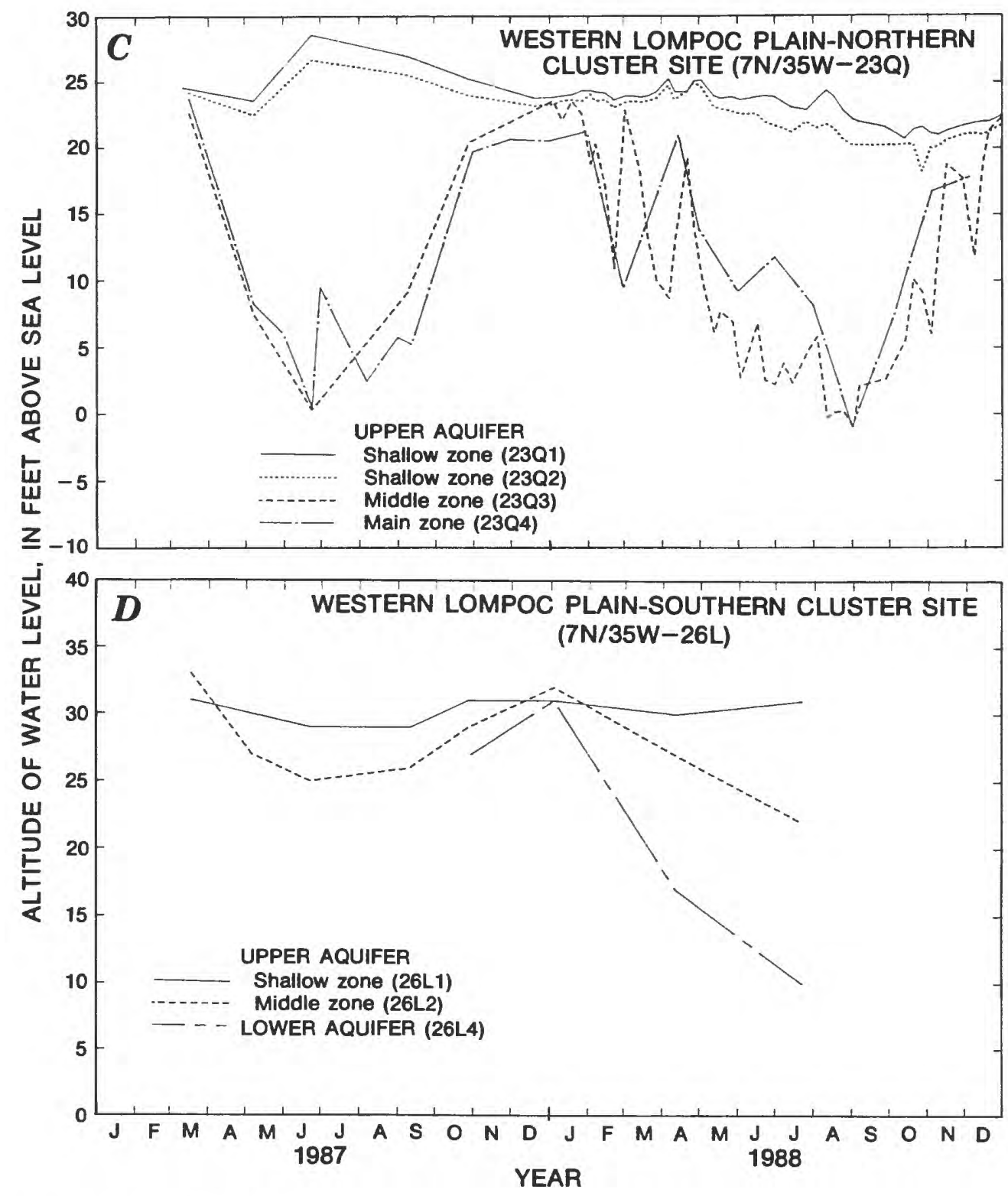

Figure 10. Continued.

The greatest water-level declines were recorded in wells at the northern site in the western plain (fig. 10C). At this site, water levels declined more than $20 \mathrm{ft}$ in wells perforated in the middle and main zones of the upper aquifer during the irrigation season in both 1987 and 1988 . This suggests that ground water in the middle and main zones was confined to a greater degree in this area. The confined conditions at this site were due partly to an increase in the thickness and proportion of silt and clay deposits in the shallow zone (Miller, 1976, p. 14). Also, consolidated rocks directly underlie the main zone in this area, and upward leakage to the main zone probably was small. This likely resulted in larger drawdowns in the middle and main zones during the irrigation season than elsewhere in the Lompoc plain.

At the southern site in the western plain, the main zone in the upper aquifer is absent (fig. 4). The lower aquifer lies directly below the middle zone in this area but is separated from it by deposits of silt and clay (see fig. 14, section $G-G^{\prime}$, in "Distribution of Stable Isotopes and Dissolved Solids"). Downward leakage of ground water between these two zones therefore was limited. Irrigation water was pumped from the middle zone in this area and from the main 
zone north of this site. Hydraulic head in the lower aquifer declined significantly during the 1988 irrigation season (fig. 10D). Because the water level in the well perforated in the lower aquifer was much lower than the water level in the well perforated in the middle zone during the irrigation season of 1988 , it was believed that pumpage from the main zone north of the site significantly lowered the hydraulic head in the lower aquifer. Historically, this part of the plain was a marshland; however, pumping of ground water from the main zone has lowered water levels below land surface in the former marshland. Also, water-level fluctuations in the well perforated in the shallow zone at this site were not similar to fluctuations in the wells perforated in the middle zone and lower aquifer. Throughout the nonirrigation season, hydraulic heads in all zones were nearly equal at this cluster site.

\section{LONG-TERM CHANGES}

Long-term water-level hydrographs for several wells that tap the upper aquifer in the Lompoc plain, and the lower aquifer in the Lompoc upland and Lompoc terrace, are shown in figure 11. These hydrographs show the highest static water-level altitude measured annually at each site. Long-term water-level records were not available for wells perforated in the lower aquifer beneath the Lompoc plain. The hydrographs show water levels in "paired" wells in the eastern (fig. 11A) and western (fig. 11B) plains. The paired wells are in close proximity to each other and allow comparison of hydraulic heads in the shallow and main zones of the upper aquifer. Short-term fluctuations in these hydrographs reflect response to seasonal pumping and recharge.

In the eastern plain, the paired wells (fig. 11A) are a short distance north of the city of Lompoc in an area considered to have free interchange of ground water between the shallow and main zones (Upson and Thomasson, 1951, p. 135). Water-level measurements from shallow-zone wells were scarce in this area; however, measurements made in well $7 \mathrm{~N} / 34 \mathrm{~W}$ 27F2 during 1941-51 were almost identical to water levels measured in wells penetrating the main zone (fig. 11A). Hydraulic head in the main zone generally declined during 1947-52 and again in 1959-60. The decline in water levels during 1947-52 reflected the drier-than-average conditions and increased irrigation pumpage that prevailed during that period. Waterlevel declines in 1959-60 corresponded to an increase in municipal pumpage by the city of Lompoc. Pumpage more than doubled from 1958 to 1961 (fig. 6). On the basis of spring water-level measurements, which are the highest water levels during most years, hydraulic head in the main zone declined approximately 10 to $15 \mathrm{ft}$ during $1930-87$ in the eastern plain.

Long-term hydrographs of paired wells in the western plain (fig. 11B) indicate a decline of about $10 \mathrm{ft}$ in hydraulic head in the main zone during 1940-88. Downward movement of ground water in this area was prevented or greatly retarded by fine deposits in the shallow zone (Upson and Thomasson, 1951 , p. 135). Water-level fluctuations in well $7 \mathrm{~N} / 35 \mathrm{~W}-25 \mathrm{~F} 6$, which is perforated in the shallow zone, only generally corresponded with the waterlevel fluctuations in well $7 \mathrm{~N} / 35 \mathrm{~W}-25 \mathrm{~F} 5$, which is perforated in the main zone. This indicates that changes in the potentiometric surface of the shallow zone occurred independently of the main zone. Hydraulic head in the shallow zone was higher than that in the heavily pumped main zone in the western plain.

Hydrographs of several wells perforated in the lower aquifer indicate that water levels in the Lompoc upland and Lompoc terrace have declined (fig. 11C, 11D). Hydrographs for wells in the Lompoc upland show a steady 15 - to 20 -foot decline in water levels from the early 1960 's to 1988 . Well $7 \mathrm{~N} / 34 \mathrm{~W}-12 \mathrm{E} 1$ is north of Mission Hills. Wells $7 \mathrm{~N} / 34 \mathrm{~W}-14 \mathrm{~F} 3$ and 7N/34W-15D1 are near the communities of Mission Hills and Vandenberg Village, respectively. Groundwater pumpage from the Lompoc upland increased considerably during 1962-66 and slightly during 1966-88 (fig. 6). In 1975-76, average annual pumpage from the Lompoc upland was about 1,900 acre-ft (Park Water Company, Mission Hills Community Services District, written commun., 1988; fig. 6); thus, pumpage was approximately equal to the estimated annual recharge from rainfall infiltration on the upland during the same period (table 2).

In monitor wells $7 \mathrm{~N} / 35 \mathrm{~W}-27 \mathrm{P} 1$ and $7 \mathrm{~N} / 35 \mathrm{~W}$ $31 \mathrm{~J} 1$ in the northeastern and southwestern Lompoc terrace, slight, but steady, declines in water level occurred from the early 1960's to 1988. Springtime water levels in production well $7 \mathrm{~N} / 35 \mathrm{~W}-33 \mathrm{~J} 2 \mathrm{~S}$ in Lompoc Canyon (fig. 11D), however, have declined 15 to $20 \mathrm{ft}$ since 1958. This production well derives most of its water from the lower member (very fine sand and silt) of the Careaga Sand. 


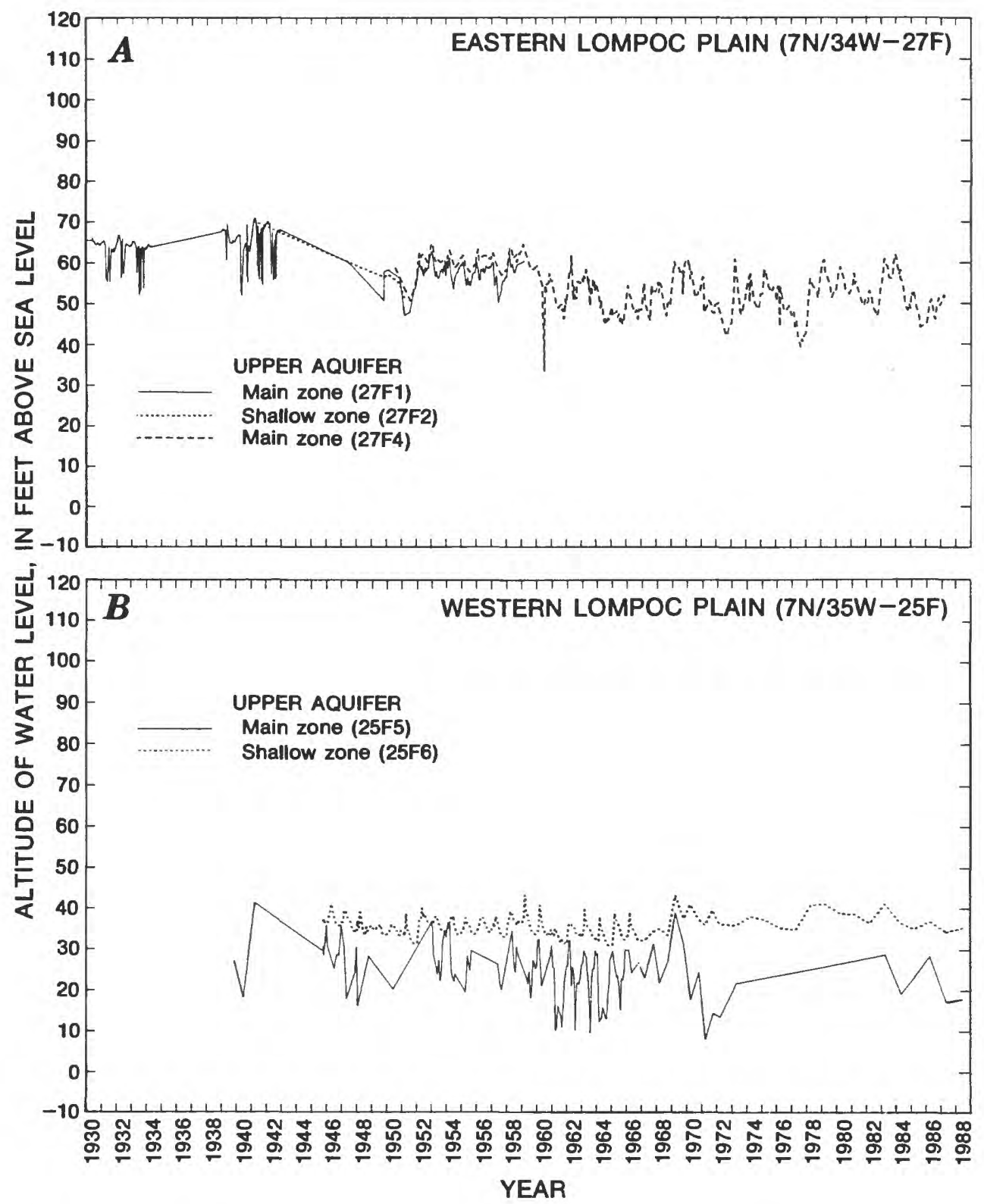

Figure 11. Altitude of water levels for selected wells in the upper (shallow and main zones) and lower aquifers, 1930-88. (See figure 8 for well locations.)

\section{GROUND-WATER QUALITY}

Water for agricultural, domestic, and most industrial needs in the Lompoc area has been obtained from wells in the basin. Previous studies (Evenson, 1966; Miller, 1976; Berenbrock, 1988) concluded that, on the basis of chemical composition, the quality of ground water in some areas of the basin has been degraded to levels that fail to meet water-quality standards recommended by the U.S. Environmental Protection Agency (EPA) $(1977,1979)$ and by the California Department of Public Health, Sanitary Engineering Section (1977). These previous reports presented results from ground-water-quality investigations that were done primarily to define the chemical character of the ground water within the Lompoc plain and areal variations in quality. However, little emphasis was placed on describing the vertical 

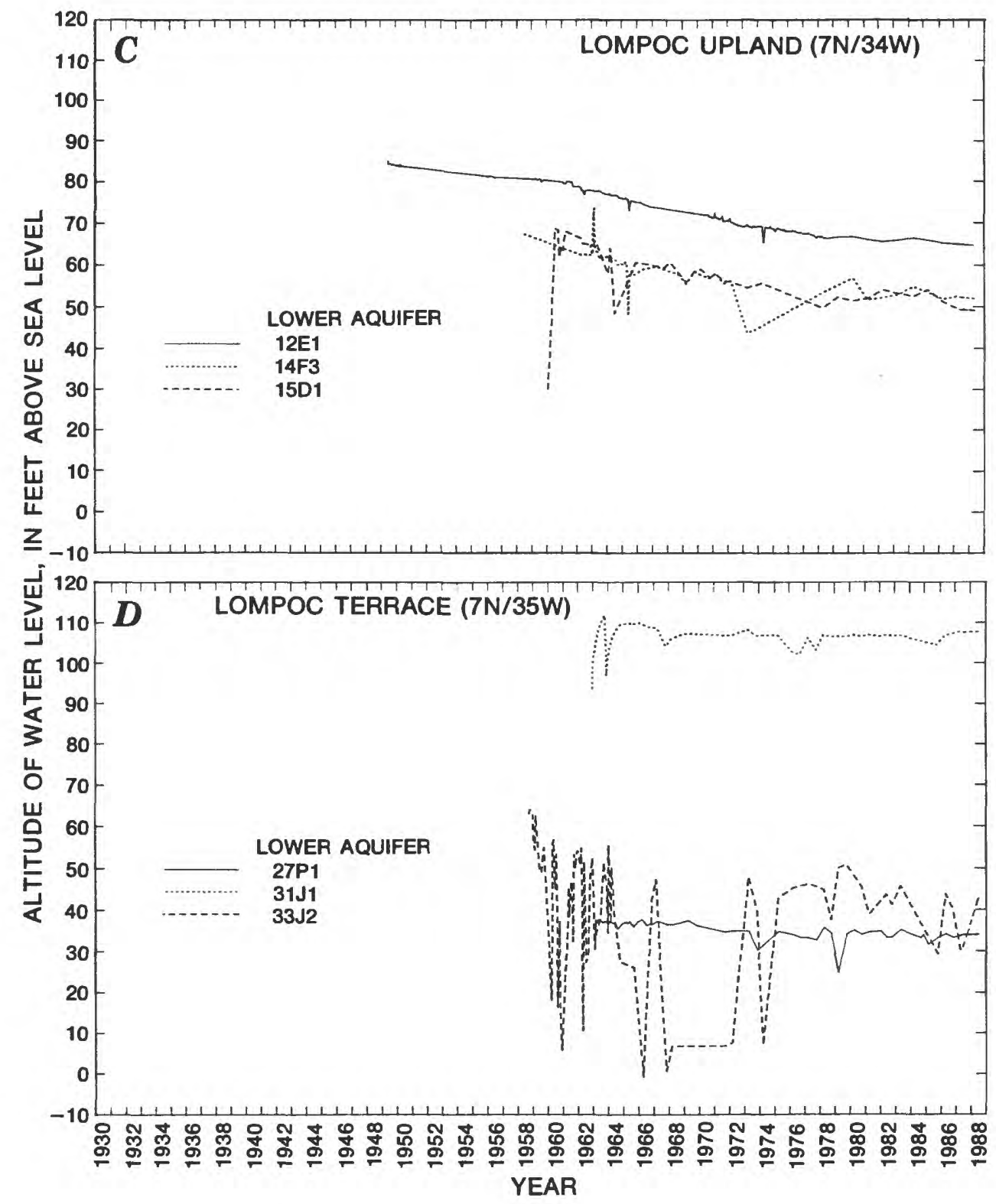

Figure 11. Continued.

variation in ground-water quality. In this report, the areal and vertical variations in ground-water quality will be described and subsequently used to determine the ground-water interaction between water-bearing zones and aquifers.

To determine the areal and vertical variations in ground-water quality in the Lompoc area, samples were collected from 79 monitor wells and two suction-cup lysimeters during the study period of March 1987 to December 1988. Thirty-two of these monitor wells were drilled by the U.S. Geological Survey in selected study plots throughout the Lompoc plain. The wells at each plot were constructed to monitor water quality in the different aquifers in the ground-water system. Figure 8 shows the location of the wells and lysimeters that were sampled for major ions and nutrients. Selected samples from these sites also were analyzed for the stable isotopes deuterium and oxygen-18. These analyses are summarized in table 6 . The complete results of the water-quality analyses for the study period are given in table 9 (at back of report). 
Table 6. Summary of dissolved solids, nitrogen, and stable isotopes in samples from selected wells, lysimeters, and surface-water sites, March 1987-December 1988

[Measured zone or aquifer was determined on the basis of well perforations and water quality. State well No.: See wellnumbering system in text. Delta oxygen-18: Number in parentheses corresponds to designation in figure 13 for both delta deuterium and delta oxygen-18. Sampled zone or aquifer was determined on the basis of well perforations and water quality. Surface-water sites: Date of analyses is shown in parentheses after site name. ${ }^{\circ} \mathrm{C}$, degrees Celsius; $\mathrm{mg} / \mathrm{L}$, milligrams per liter; per mil, parts per thousand; <, actual value is less than value shown; --, no data; na, not applicable]

\begin{tabular}{|c|c|c|c|c|}
\hline \multirow[b]{2}{*}{ State well No. } & \multirow{2}{*}{$\begin{array}{l}\text { Solids, } \\
\text { sum of } \\
\text { constituents, } \\
\text { dissolved, } \\
\text { average } \\
(\mathrm{mg} / \mathrm{L})\end{array}$} & \multirow{2}{*}{$\begin{array}{l}\text { Nitrogen, } \\
\text { nitrite plus } \\
\text { nitrate } \\
\text { dissolved, } \\
\text { average } \\
\text { (mg/L as } \mathrm{N})\end{array}$} & \multicolumn{2}{|c|}{ April 1988} \\
\hline & & & $\begin{array}{c}\text { Delta } \\
\text { deuterium } \\
\text { (per mil) }\end{array}$ & $\begin{array}{c}\text { Delta } \\
\text { oxygen-18 } \\
\text { (per mil) }\end{array}$ \\
\hline \multicolumn{5}{|c|}{ Upper Aquifer--Shallow Zone } \\
\hline $\begin{array}{r}7 \mathrm{~N} / 34 \mathrm{~W}-22 \mathrm{Q} 8 \\
27 \mathrm{~K} 4 \\
27 \mathrm{P} 6 \\
28 \mathrm{~B} 5 \\
29 \mathrm{~F} 2 \\
29 \mathrm{~N} 3 \\
29 \mathrm{~N} 4 \\
31 \mathrm{R} 2 \\
32 \mathrm{N1}^{3} \\
33 \mathrm{E} 5 \\
35 \mathrm{~K} 14\end{array}$ & $\begin{array}{r}1892 \\
943 \\
876 \\
1779 \\
1,392 \\
3,428 \\
3,165 \\
1,21,909 \\
1,22,083 \\
3,277 \\
11,430\end{array}$ & $\begin{array}{c}11.1 \\
1.6 \\
<.10 \\
1<.10 \\
.17 \\
25 \\
<.10 \\
-- \\
-- \\
.29 \\
17.30\end{array}$ & $\begin{array}{c}- \\
-33.0 \\
-33.0 \\
-- \\
-33.5 \\
-31.0 \\
-31.5 \\
-- \\
-- \\
-33.0 \\
--\end{array}$ & $\begin{array}{l}-- \\
-4.85(7) \\
-5.35(12) \\
-- \\
-5.05(16) \\
-4.65(18) \\
-4.80(19) \\
-- \\
-- \\
-4.90(23) \\
--\end{array}$ \\
\hline $\begin{array}{c}7 \mathrm{~N} / 35 \mathrm{~W}-13 \mathrm{~N} 2^{4} \\
16 \mathrm{R} 1 \\
17 \mathrm{G} 1 \\
17 \mathrm{Q} 6 \\
23 \mathrm{~B} 2 \\
23 \mathrm{Q} 1 \\
23 \mathrm{Q} 2 \\
23 \mathrm{Q} 5 \mathrm{LYS} \\
26 \mathrm{~L} 1 \\
\text { 26L3LYS }\end{array}$ & $\begin{array}{r}1,542 \\
11,770 \\
3,325 \\
8,010 \\
871 \\
5,716 \\
5,374 \\
4,790 \\
3,318 \\
3,275\end{array}$ & $\begin{array}{c}1- \\
1<.10 \\
<.10 \\
<.10 \\
<.10 \\
60 \\
51 \\
113 \\
37 \\
52\end{array}$ & $\begin{array}{c}-36.0 \\
- \\
- \\
- \\
-34.5 \\
-34.0 \\
-31.0 \\
- \\
-32.5 \\
--\end{array}$ & $\begin{array}{l}-5.75(25) \\
-- \\
-- \\
-- \\
-5.20(28) \\
-4.75(29) \\
-4.65(30) \\
-- \\
-5.00(33) \\
--\end{array}$ \\
\hline \multicolumn{5}{|c|}{ Upper Aquifer--Middle Zone } \\
\hline $\begin{aligned} 7 \mathrm{~N} / 34 \mathrm{~W}-26 \mathrm{R} 2 \\
27 \mathrm{E} 4 \\
27 \mathrm{~K} 5 \\
27 \mathrm{~N} 6 \\
28 \mathrm{M} 1 \\
28 \mathrm{Q} 1 \\
29 \mathrm{H} 3 \\
29 \mathrm{Li} 1^{3} \\
29 \mathrm{~N} 5\end{aligned}$ & $\begin{array}{r}1,990 \\
2,273 \\
983 \\
11,460 \\
2,900 \\
1,470 \\
1,475 \\
1,21,739 \\
1,744\end{array}$ & $\begin{array}{l}124 \\
<.10 \\
<.10 \\
<.10 \\
12 \\
.24 \\
<.10 \\
-. \\
.24\end{array}$ & $\begin{array}{l}-33.5 \\
-36.5 \\
-31.5 \\
- \\
-33.5 \\
-\overline{-} \\
-29.5 \\
-\overline{37.5}\end{array}$ & $\begin{array}{l}-4.95(5) \\
-5.30(6) \\
-4.70(8) \\
-- \\
-4.95(13) \\
-- \\
-4.60(17) \\
-- \\
-5.55(20)\end{array}$ \\
\hline $\begin{array}{r}7 \mathrm{~N} / 35 \mathrm{~W}-23 \mathrm{Q} 3 \\
26 \mathrm{~L} 2\end{array}$ & $\begin{array}{r}1,280 \\
646\end{array}$ & $\begin{array}{l}.68 \\
.35\end{array}$ & $\begin{array}{l}-35.0 \\
-33.0\end{array}$ & $\begin{array}{l}-5.55(31) \\
-5.50(34)\end{array}$ \\
\hline
\end{tabular}

Footnotes at end of table. 
Table 6. Summary of dissolved solids, nitrogen, and stable isotopes in samples from selected wells, lysimeters, and surface-water sites, March 1987-December 1988-Continued

\begin{tabular}{ccccc}
\hline & $\begin{array}{c}\text { Solids, } \\
\text { Sum of } \\
\text { constituents, } \\
\text { dissolved, } \\
\text { average } \\
(\mathrm{mg} / \mathrm{L})\end{array}$ & $\begin{array}{c}\text { Nitrogen, } \\
\text { nitrite plus }\end{array}$ & $\begin{array}{c}\text { nitrate } \\
\text { dissolved, }\end{array}$ & average \\
\cline { 3 - 4 } & $(\mathrm{mg} / \mathrm{L}$ as $\mathrm{N})$ & April 1988 & Delta & Delta \\
deuterium & (per mil) & $\begin{array}{c}\text { oxygen-18 } \\
\text { (per mil) }\end{array}$ & &
\end{tabular}

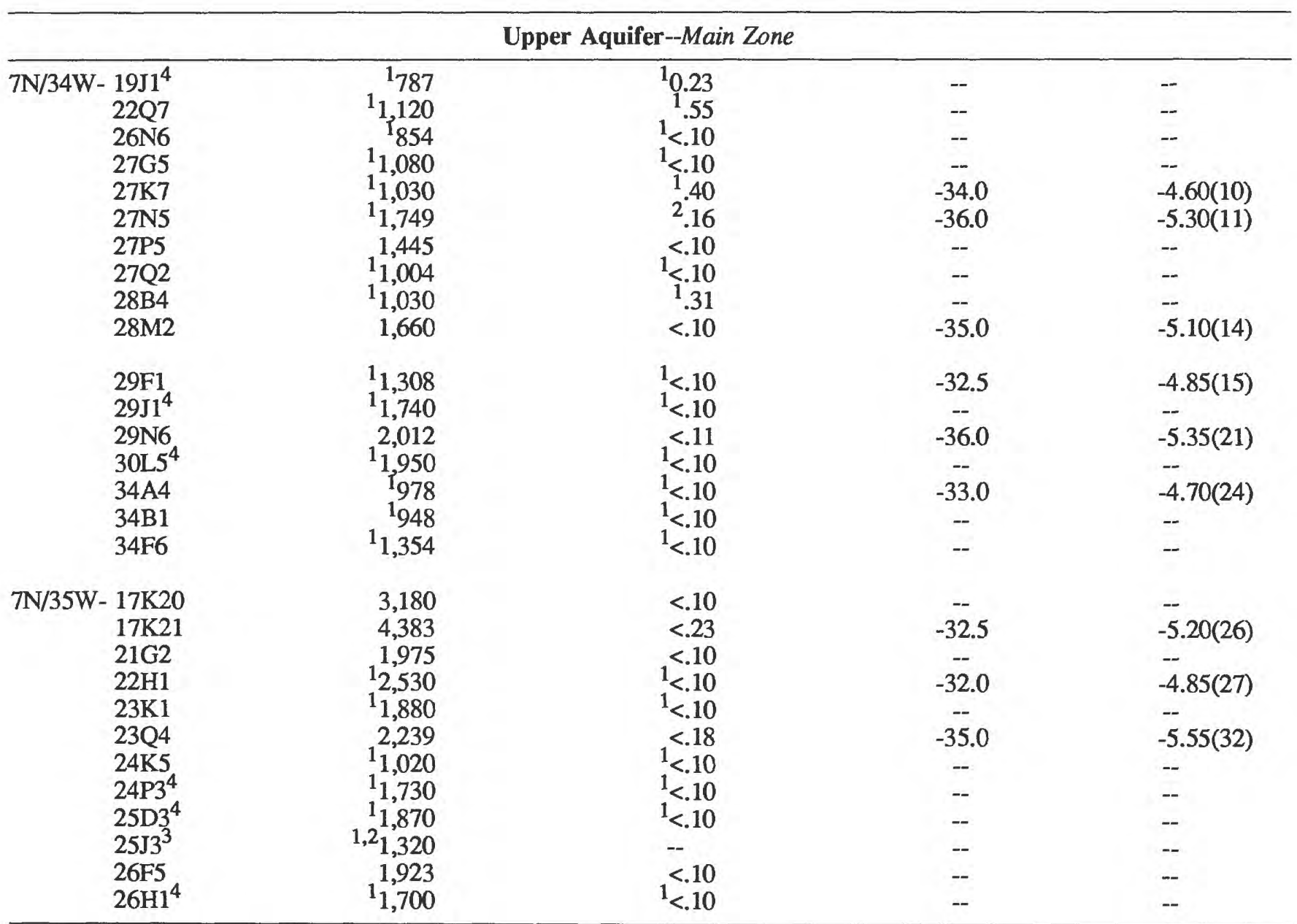

Lower Aquifer

\begin{tabular}{|c|c|c|c|c|}
\hline $7 \mathrm{~N} / 33 \mathrm{~W}-19 \mathrm{Q} 2$ & $1_{479}$ & ${ }^{1} 0.33$ & -- & -- \\
\hline $7 \mathrm{~N} / 34 \mathrm{~W}-14 \mathrm{~F} 4$ & ${ }^{1} 512$ & 1.83 & $5_{-38.5}$ & $5-5.60(1)$ \\
\hline $14 \mathrm{G} 2$ & $1_{428}$ & ${ }^{1} .59$ & - & -- \\
\hline 15D3 & -- & -- & -36.0 & $-5.70(2)$ \\
\hline $15 \mathrm{E} 3$ & ${ }^{1} 503$ & ${ }^{1} .36$ & -37.0 & $-5.75(3)$ \\
\hline $20 \mathrm{~K} 6$ & 714 & .13 & $5-37.5$ & $5-5.60(4)$ \\
\hline $20 \mathrm{P} 3$ & ${ }^{1} 562$ & $1<.10$ & -- & -- \\
\hline $27 \mathrm{~K} 6$ & 655 & $<.10$ & -41.0 & $-6.35(9)$ \\
\hline 29N7 & 1,019 & $<.12$ & -38.0 & $-5.75(22)$ \\
\hline
\end{tabular}

Footnotes at end of table. 
Table 6. Summary of dissolved solids, nitrogen, and stable isotopes in samples from selected wells, lysimeters, and surface-water sites, March 1987-December 1988-Continued

\begin{tabular}{|c|c|c|c|c|}
\hline \multirow[b]{2}{*}{ State well No. } & \multirow{2}{*}{$\begin{array}{c}\text { Solids, } \\
\text { sum of } \\
\text { constituents, } \\
\text { dissolved, } \\
\text { average } \\
(\mathrm{mg} / \mathrm{L})\end{array}$} & \multirow{2}{*}{$\begin{array}{l}\text { Nitrogen, } \\
\text { nitrite plus } \\
\text { nitrate } \\
\text { dissolved, } \\
\text { average } \\
\text { (mg/L as } \mathrm{N} \text { ) }\end{array}$} & \multicolumn{2}{|c|}{ April 1988} \\
\hline & & & $\begin{array}{c}\text { Delta } \\
\text { deuterium } \\
\text { (per mil) }\end{array}$ & $\begin{array}{c}\text { Delta } \\
\text { oxygen-18 } \\
\text { (per mil) }\end{array}$ \\
\hline \multicolumn{5}{|c|}{ Lower aquifer--Continued } \\
\hline $7 \mathrm{~N} / 35 \mathrm{~W}-26 \mathrm{~L} 4$ & 818 & 0.14 & -36.0 & $-5.65(35)$ \\
\hline $33 \mathrm{~J} 2$ & 418 & 2.4 & -34.5 & $-5.45(36)$ \\
\hline $33 \mathrm{~J} 4$ & 674 & .21 & -- & -- \\
\hline 35E1 & ${ }^{1} 368$ & ${ }^{1} 10$ & -35.5 & $-5.65(37)$ \\
\hline
\end{tabular}

\section{Surface-water sites}

\begin{tabular}{|c|c|c|c|}
\hline Santa Ynez River ${ }^{6}(2 / 29 / 88) \ldots 1,7410$ & -- & -29.9 & -4.95 \\
\hline Santa Ynez River $6(6 / 87) \ldots{ }^{1,7} 1,280$ & - & -34.5 & -5.65 \\
\hline Lompoc Regional Wastewater & & & \\
\hline Treatment Plant ${ }^{8}(6 / 88) \ldots$ & -- & -39.0 & -5.20 \\
\hline Lake Cachuma $^{10}(6 / 88)$. & -- & -29.0 & -2.60 \\
\hline
\end{tabular}

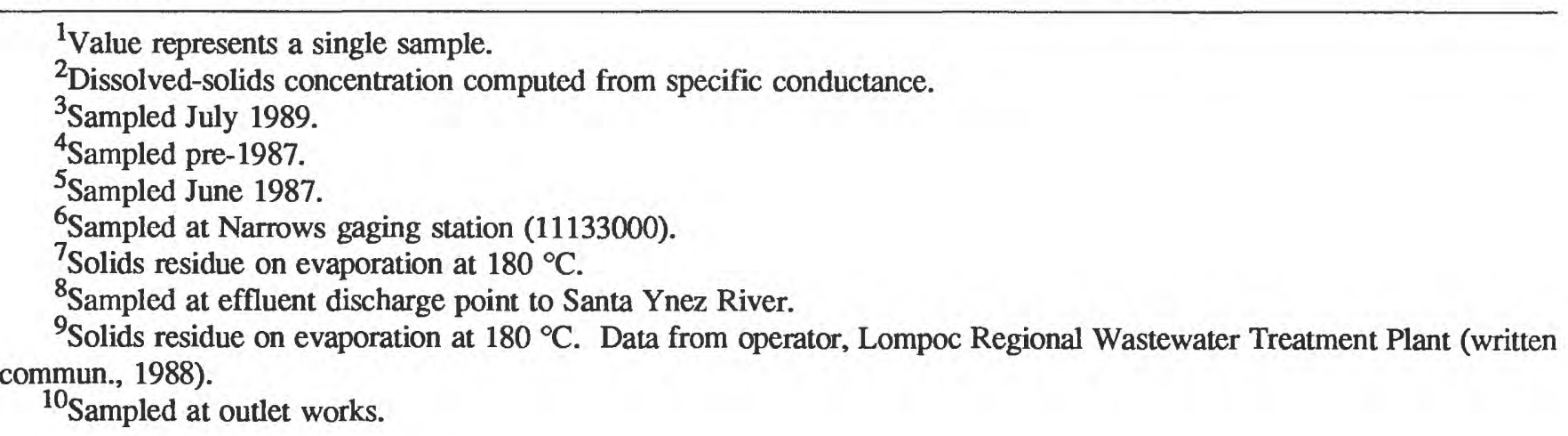

\section{AREAL VARIATION IN GROUND-WATER QUALITY}

The quality of ground water in the Lompoc area varied areally within individual water-bearing deposits. The distribution of dissolved solids and the chemical quality of samples from selected wells during 1987-88 are shown in figure 12 for the upper aquifer (shallow, middle, and main zones) and for the lower aquifer. Where complete chemical analyses were not available, the dissolved-solids concentrations were estimated by multiplying the specific conductance by a factor of 0.83 for the shallow zone, 0.74 for the middle zone, and 0.66 for the main zone and for the lower aquifer. These factors were determined using linear-regression techniques for samples collected by the U.S. Geological Survey in the Lompoc area.

Representative chemical analyses of ground water throughout the Lompoc area are shown pictorially in figure 12 using a method suggested by Stiff (1951). The water-quality diagrams show the general quality of the water and areal differences in chemical character of the water. Analyses with similarly shaped diagrams represent ground water of similar chemical characteristics with regard to the major ions. Changes 
in the width of the diagrams are approximate indications of the differences in the concentrations of dissolved constituents.

\section{UPPER AQUIFER}

\section{Shallow Zone}

Average dissolved-solids concentration during 1987-88 in the shallow zone of the upper aquifer ranged from $871 \mathrm{mg} / \mathrm{L}$ in the northwestern plain to $8,010 \mathrm{mg} / \mathrm{L}$ in the coastal area (fig. 12 , table 6). In the eastem plain, in areas where there has been little, if any, history of agricultural activity, the shallow zone had dissolved-solids concentrations less than $1,000 \mathrm{mg} / \mathrm{L}$. However, in some areas of the plain that have been irrigated, dissolved-solids concentrations were greater than $5,000 \mathrm{mg} / \mathrm{L}$. The dissolved-solids concentrations in the shallow zone in irrigated areas commonly were more than twice those in the main zone, and several times higher than those in the lower aquifer.

In the coastal area, average dissolved-solids concentration in the shallow zone increased dramatically--to as great as $8,010 \mathrm{mg} / \mathrm{L}$--with sodium and chloride as the major ions. Chloride to sulfate ratios were highest for samples from wells near the coast and were at least three times higher than those inland (table 9). As discussed by Hem (1985, p. 205), the ratios of selected ions may be used as indicators of seawater intrusion. Accordingly, the high sodium and chloride concentrations in the shallow zone, along with chloride to sulfate ratios, suggest that seawater has been the source of the ground-water degradation near the coast.

Beneath the irrigated fields, ground water from the shallow zone was characterized by high concentrations of sulfate, boron, and nitrate during 1987-88. Concentrations of sulfate generally exceeded 1,000 $\mathrm{mg} / \mathrm{L}$, and in samples from some wells were as high as $2,900 \mathrm{mg} / \mathrm{L}$. Nitrate-nitrogen concentrations ranged from about 11 to $81 \mathrm{mg} / \mathrm{L}$ in samples from wells in the central and western plain and were as high as $130 \mathrm{mg} / \mathrm{L}$ from lysimeter $7 \mathrm{~N} / 35 \mathrm{~W}-23 \mathrm{Q} 5 \mathrm{LYS}$ in the unsaturated zone beneath an irrigated field in the western plain (table 9). However, the nitrate-nitrogen concentrations in samples from wells in the eastern part of the plain generally were less than $1 \mathrm{mg} / \mathrm{L}$. Boron concentrations exceeded the recommended level of $750 \mu \mathrm{g} / \mathrm{L}$ for sensitive plants (Ayers and Westcott, 1976, p. 7) throughout the plain; in the western plain, boron concentrations exceeded $3,000 \mu \mathrm{g} / \mathrm{L}$.

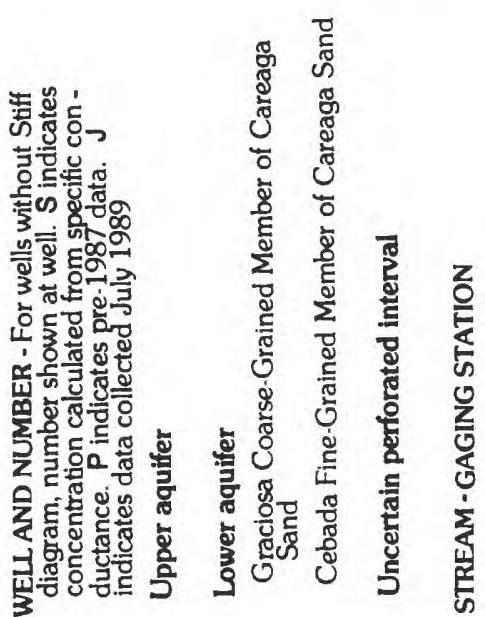

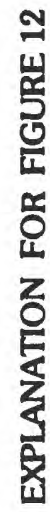

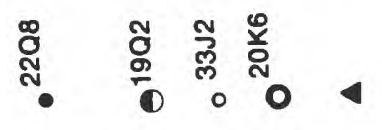

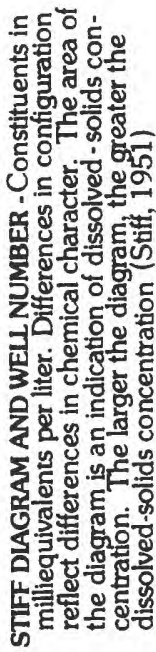

1
1
8
1
1

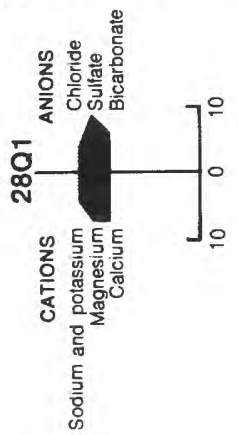





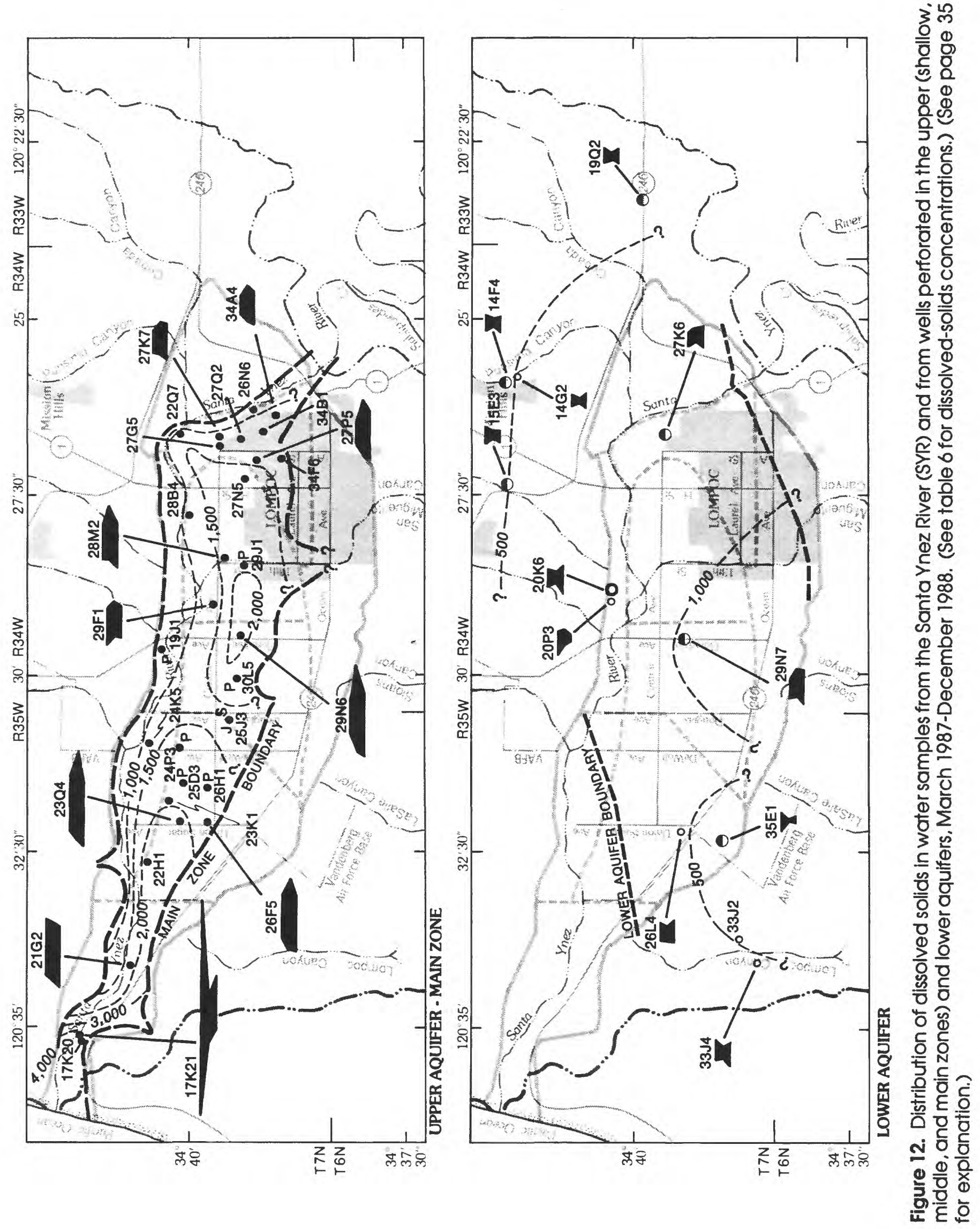


\section{Middle Zone}

In some respects, the distribution of dissolved solids in the middle zone was similar to that in the shallow zone during 1987-88. The middle zone contained ground water with an average dissolved-solids concentration less than $1,000 \mathrm{mg} / \mathrm{L}$ adjacent to the Santa Ynez River in the eastern plain. Beneath the irrigated or formerly irrigated fields in the northeastern plain (fig. 12, table 6), average dissolvedsolids concentration was greater than $2,000 \mathrm{mg} / \mathrm{L}$. Unlike the shallow zone, however, the middle zone did not contain ground water of high dissolved-solids concentration beneath the irrigated fields in the western plain. For example, the average dissolvedsolids concentration in a sample from well $7 \mathrm{~N} / 35 \mathrm{~W}$ $26 \mathrm{~L} 2$ in the western plain was only $646 \mathrm{mg} / \mathrm{L}$. The source of the water of low dissolved-solids concentration in this area probably was underflow from the terrace deposits and Orcutt Sand, which are contiguous to the middle zone on the southern edge of the plain.

The source of the high dissolved-solids concentrations in the middle zone in the northeastern plain was downward leakage from the shallow zone. In the eastern plain, the silt and clay layers of the shallow zone are less extensive than in the western plain and water moved freely between the zones. As the ground water of high dissolved-solids concentration in the northeastern plain moved downgradient beneath the western plain, it was diluted by the water that contained low concentrations of dissolved solids from the southern edge of the plain. The presence of water of low dissolved-solids concentration in the middle zone indicates that little, if any, of the water of high dissolved-solids concentration from the shallow zone recharged the underlying middle zone in the western plain. The lack of leakage from the shallow zone to the middle zone was the result of extensive silt and clay layers in the shallow zone that restrict downward leakage in the western plain.

\section{Main Zone}

The average dissolved-solids concentration in the main zone ranged from about $718 \mathrm{mg} / \mathrm{L}$ in the eastern plain near the Santa Ynez River to more than 4,500 $\mathrm{mg} / \mathrm{L}$ in the coastal area during 1987-88 (fig. 12, table 6). Throughout most of the plain, dissolvedsolids concentration ranged from 1,500 to 2,000 $\mathrm{mg} / \mathrm{L}$. Sulfate was usually the dominant anion, and calcium and magnesium were usually the dominant cations. As in the shallow and middle zones, dissolved-solids concentrations increased west and south of the Santa Ynez River in the northeastern plain. However, unlike the middle zone (in which dissolved solids decreased in the western plain), dissolved-solids concentrations in the main zone were high throughout the plain--exceeding concentrations in the overlying middle zone throughout the western plain.

Nitrate-nitrogen concentrations in the main zone generally were less than $1 \mathrm{mg} / \mathrm{L}$ (table 6). The lack of nitrate-nitrogen in the main zone suggests that leakage of water with high dissolved-solids concentration from the shallow zone occurred only in the eastern plain, where nitrate-nitrogen concentrations in the shallow zone also were minimal. As stated earlier, the presence of water of low dissolved-solids concentration in the middle zone beneath the western plain during 1987-88 also indicates insignificant downward migration of water from the shallow zone.

West of Union Sugar Avenue in the western plain, the average dissolved-solids concentration in the main zone generally exceeded $2,000 \mathrm{mg} / \mathrm{L}$. The increase in dissolved solids was due almost entirely to increases in sodium and chloride concentrations. Evenson (1964) suggested that upward migration of ground water through fractures within the underlying consolidated rocks was responsible for the increase in dissolved solids in this part of the basin (see fig. 14 in "Distribution of Stable Isotopes and Dissolved Solids"). In the coastal area, where dissolved-solids concentrations exceeded $4,500 \mathrm{mg} / \mathrm{L}$, the predominant ions were sodium and chloride. As in the shallow zone, the high concentrations of sodium and chloride, along with high chloride to sulfate ratios, suggest that seawater has been the source of the ground-water degradation.

\section{LOWER AQUIFER}

In general, ground water in the lower aquifer has significantly lower dissolved-solids concentrations than water in the upper aquifer. Beneath the Lompoc upland, ground water in the lower aquifer contained dissolved-solids concentrations of approximately 500 $\mathrm{mg} / \mathrm{L}$ during 1987-88. The primary source of recharge to the lower aquifer in the uplands has been the direct infiltration of precipitation, which accounts for the relatively low dissolved-solids concentrations. The water-quality diagrams in figure $\mathbf{1 2}$ also illustrate the relatively low percentage of sulfate in the lower aquifer in comparison with the upper aquifer. The low sulfate concentrations and the odor of hydrogen 
sulfide that was evident when many of the wells in the lower aquifer were pumped suggest that sulfate reduction may have been occurring within this aquifer (Hem, 1985, p. 117).

Average dissolved-solids concentration in sparse samples from the lower aquifer beneath the Lompoc plain was $655 \mathrm{mg} / \mathrm{L}$ in the eastern plain, $818 \mathrm{mg} / \mathrm{L}$ in the southem part of the western plain, and 1,019 $\mathrm{mg} / \mathrm{L}$ in the central plain. Water-level data (fig. 10) indicate that ground-water flow was upward from the lower aquifer to the main zone beneath the Lompoc plain. Therefore, it is unlikely that downward migration of ground water from the main zone was the source of the increased dissolved-solids concentrations toward the central plain. Potentiometric contours for the lower aquifer (fig. 9) indicate that ground-water movement beneath the southern, western, and central parts of the plain was from the southern edge of the plain to the north. This suggests that runoff from the Santa Ynez Mountains has been a major source of recharge to the lower aquifer beneath the plain.

Streams that drain the Santa Ynez Mountains frequently had dissolved-solids concentrations in excess of $1,000 \mathrm{mg} / \mathrm{L}$ (table 10 , at back of report). This supports the suggestion that the infiltration of streamflow from the mountains to the south was a probable source of the higher dissolved-solids concentrations in the lower aquifer beneath the plain. In addition, the shallow zone directly overlies the lower aquifer along the southern edge of the plain (see fig. 14 in "Distribution of Stable Isotopes and Dissolved Solids"). Thus, downward migration of ground water of high dissolved-solids concentration from the shallow zone in this area also may have been a source of the higher dissolved-solids concentrations in the ground water of the lower aquifer beneath the plain.

Dissolved-solids concentrations in samples from the lower aquifer beneath the Lompoc terrace ranged from $368 \mathrm{mg} / \mathrm{L}$ near the eastern edge of the terrace to $674 \mathrm{mg} / \mathrm{L}$ near Lompoc Canyon. The sample from well $7 \mathrm{~N} / 35 \mathrm{~W}-35 \mathrm{E} 1$ had the lowest dissolved-solids concentration; this well was perforated in the Orcutt Sand, which forms part of the lower aquifer (table 1). Infiltration of precipitation probably was the source of the water of low dissolved-solids concentration. Well $7 \mathrm{~N} / 35 \mathrm{~W}-33 \mathrm{~J} 4$ yielded the sample with the highest dissolved-solids concentration; it was perforated in the Careaga Sand. The higher dissolved-solids concentration from the Lompoc Canyon area suggests that this water probably was a mixture formed by infiltration of precipitation and infiltration of runoff from the Santa Ynez Mountains to the south.

\section{VERTICAL VARIATION IN GROUND-WATER QUALITY}

Comparison of dissolved-solids and stable-isotope concentrations along selected geohydrologic cross sections of the Lompoc area help to explain the vertical variations in chemical quality. Used alone, dissolved-solids or stable-isotope concentrations may not provide a unique explanation of the observed vertical variation in chemical quality. However, when the two are used together, along with hydrologic data presented in earlier sections of this report, the variation in chemical quality can be reasonably explained. A brief description of stable-isotope chemistry is included in the following paragraphs.

\section{STABLE-ISOTOPE CHEMISTRY}

The ratios of isotopes of oxygen (oxygen-18 $\left[{ }^{18} \mathrm{O}\right]$ : oxygen-16 $\left[{ }^{16} \mathrm{O}\right]$ ) and hydrogen (deuterium, $\mathrm{D}\left[{ }^{2} \mathrm{H}\right]$ : hydrogen $\left.\left[{ }^{1} \mathrm{H}\right]\right)$ in ground water are indicators of its hydrologic history. The isotope ratios are expressed in delta notations $(\delta)$ as per mil (parts per thousand [\%o]) differences relative to a standard known as standard mean ocean water:

$$
\begin{gathered}
\delta^{18} \mathrm{O}=\frac{\left({ }^{18} \mathrm{O} /{ }^{16} \mathrm{O}\right) \text { sample }-\left({ }^{18} \mathrm{O} /{ }^{16} 0\right) \text { standard }}{\left({ }^{18} \mathrm{O} /{ }^{16} \mathrm{O}\right) \text { standard }} \times 1,000, \text { and } \\
\delta \mathrm{D}=\frac{\left({ }^{2} \mathrm{H} /{ }^{1} \mathrm{H}\right) \text { sample }-\left({ }^{2} \mathrm{H} /{ }^{1} \mathrm{H}\right) \text { standard }}{\left({ }^{2} \mathrm{H} /{ }^{1} \mathrm{H}\right) \text { standard }} \times 1,000 .
\end{gathered}
$$

Craig (1961) found that a linear relation existed between $\delta \mathrm{D}$ and $\delta^{18} \mathrm{O}$ in meteoric waters throughout the world. This relation is referred to as the global meteoric water line (see fig. 13).

The isotopic composition of seawater is nearly constant, but it undergoes isotopic fractionation during transfer from the ocean surface to the vapor phase. Further fractionation occurs as water vapor condenses from the atmosphere, leaving the remaining vapor relatively depleted in the heavier isotopes (oxygen-18 and deuterium). Thus, the last rain that falls from a vapor mass as it moves inland will be isotopically 


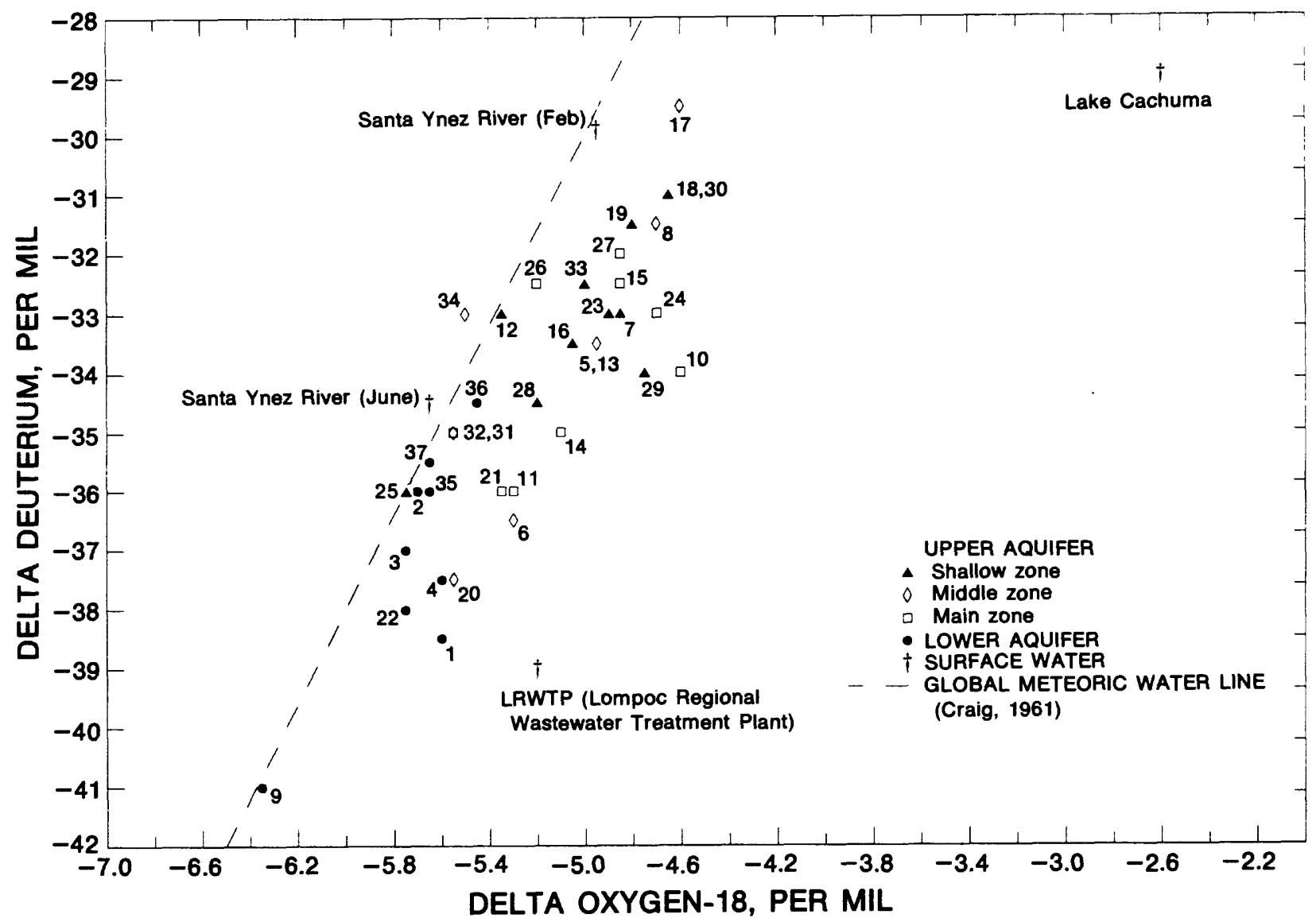

Figure 13. Relation between delta deuterium and delta oxygen-18 values for samples from selected wells and surface-water sites. (Sample-identification numbers at data points correspond to numbers in delta oxygen-18 column in table 6.)

lighter than the first rain that falls. Isotopic fractionation is dependent on air temperature as well as distance from the ocean. The net result is that precipitation from a given storm becomes isotopically lighter as the storm moves inland, and precipitation that forms at lower temperatures is also lighter than precipitation that forms at higher temperatures (Fournier and Thompson, 1980, p. 3).

Evaporation also causes isotopic fractionation. When water is evaporated, the lighter isotopes of oxygen and hydrogen are preferentially partitioned into the vapor phase, causing the remaining water to be isotopically heavier. Further change to the isotopic composition does not occur at the low temperatures of most ground-water systems after the recharge water has migrated below the depth at which evaporation occurs. Therefore, any subsequent changes in the isotopic composition of ground water along a flow line generally reflect only the mixing within the aquifer system or concentration by evaporation in a discharge area.

\section{DISTRIBUTION OF STABLE ISOTOPES AND DISSOLVED SOLIDS}

Results of water analyses for oxygen and hydrogen isotopes are plotted graphically in figure 13. Generalized geohydrologic sections showing the distribution of dissolved-solids concentration and $\delta^{18} \mathrm{O}$ values are shown in figure 14 . As shown in both figures, samples from the upper aquifer were enriched in oxygen-18 (values are less negative) in comparison with samples from the lower aquifer. The isotopic data for samples from the upper aquifer are shifted slightly to the right of the global meteoric water line (fig. 13), indicating some evaporation of the recharge water prior to infiltration into waterbearing deposits. Most of the samples from the upper aquifer were from wells in or near irrigated fields (fig. 14).

Dissolved-solids concentrations in samples from the shallow zone of the upper aquifer increased from less than $1,000 \mathrm{mg} / \mathrm{L}$ in the eastern plain near the Santa Ynez River to more than $5,000 \mathrm{mg} / \mathrm{L}$ in the 
western plain (fig. 14 , section $F-F^{\prime}$ ). Although the dissolved-solids concentrations increased dramatically, the $\delta^{18} \mathrm{O}$ values remained about the same throughout most of the plain. This suggests that the high concentrations of dissolved solids in the ground water of the shallow zone were a result of mixing as opposed to evaporation. Therefore, the higher concentrations of dissolved solids in the western plain must have been the result of accumulation of salts from upgradient irrigated fields, and (or) the dissolution of soluble salts in the shallow zone. If recycling and evaporation were the cause of the high dissolved-solids concentration, the $\delta^{18} \mathrm{O}$ values of the water of high dissolved-solids concentration would have been significantly heavier (less negative) than the $\delta^{18} \mathrm{O}$ values of the water of low dissolved-solids concentration.

Ground water of high dissolved-solids concentration from the shallow zone leaked to the middle zone beneath the northeastern plain as indicated by high dissolved-solids concentrations in samples from wells $7 \mathrm{~N} / 34 \mathrm{~W}-28 \mathrm{M} 1$ and 27E4 (fig. 14, section $F-F^{\prime}$ ). This water of high dissolved-solids concentration continued to move downward and degrade the quality of the main zone between wells $7 \mathrm{~N} / 34 \mathrm{~W}-27 \mathrm{~K} 7$ and 29N6 (fig. 14, section $F-F^{\prime}$ ). Ground water sampled from well $7 \mathrm{~N} / 34 \mathrm{~W}-29 \mathrm{~N} 6$ had an average dissolvedsolids concentration of $2,012 \mathrm{mg} / \mathrm{L}$. West of well $7 \mathrm{~N} / 34 \mathrm{~W}-29 \mathrm{~N} 6$ and east of well 7N/35W-23Q4, little if any leakage occurred from the overlying shallow zone, as indicated by relatively constant dissolvedsolids concentrations and $\delta^{18} \mathrm{O}$ values in the underlying water-bearing zones beneath the western plain.

The main zone overlies the lower aquifer throughout the eastern and central parts of the Lompoc plain (see fig. 14). Upward leakage from the lower aquifer beneath the central plain and lateral movement along the southern and northern margins of the plain contributed significant quantities of water to the main zone. Production wells in the main zone between wells $7 \mathrm{~N} / 34 \mathrm{~W}-29 \mathrm{~N} 6$ and $7 \mathrm{~N} / 35 \mathrm{~W}-23 \mathrm{Q} 4$ yielded water with an average dissolved-solids concentration of about $1,800 \mathrm{mg} / \mathrm{L}$ (fig. 12). This decrease in dissolved solids was the result of leakage of water of low dissolved-solids concentration from the lower aquifer. The increase in dissolved solids in samples from well $7 \mathrm{~N} / 35 \mathrm{~W}-23 \mathrm{Q} 4$ in the western plain (fig. 14, section $F-F^{\prime}$ ) probably was the result of upward migration of water of high dissolved-solids concentration from underlying consolidated rocks.
Sparse chemical analyses indicate that dissolved-solids concentrations of water in the consolidated rocks were approximately $11,000 \mathrm{mg} / \mathrm{L}$ (D.A. Cole, Unocal Corporation, written commun., 1989). As shown in figure 14 (section $F-F^{\prime}$ ), the consolidated rocks directly underlie the main zone in the western Lompoc plain.

At the eastern edge of the coastal area, concentrations of dissolved solids in the main zone were lower in samples from well $7 \mathrm{~N} / 35 \mathrm{~W}-21 \mathrm{G} 2$ than in samples from well $7 \mathrm{~N} / 35 \mathrm{~W}-23 \mathrm{Q} 4$ in the western plain (fig. 14, section $F-F^{\prime}$ ). Less clay and silt in the shallow zone at well $7 \mathrm{~N} / 35 \mathrm{~W}-21 \mathrm{G} 2$ has probably allowed free interchange of water between the shallow, middle, and main zones in this area, similar to the northwestern plain (Upson and Thomasson, 1951, p. 146). Also, average dissolved-solids concentrations (fig. 12) indicate that the eastern edge of the coastal area probably received recharge from the Santa Ynez River. Thus, recharge from the Santa Ynez River in this region apparently diluted the water entering the main zone through seepage from the underlying consolidated rocks.

Water of extremely high dissolved-solids concentration in consolidated rocks has a high proportion of sodium and chloride ions and is almost completely depleted in sulfate, thus indicating reducing conditions. The influence of this water entering the main zone in the western plain was manifested by increases in the dissolved-solids concentrations, due primarily to increases in sodium and chloride (table 6). In the western plain, the main zone directly overlies the consolidated rocks (fig. 14, section $F-F^{\prime}$ ). Pictorially, the water-quality diagrams in figure 12 indicate an increase in sodium and chloride concentrations but virtually no change in sulfate concentration. Simple mixing of dissolved constituents indicates that less than 3 percent of the water from consolidated rocks (containing $11,000 \mathrm{mg} / \mathrm{L}$ dissolved solids) was needed to increase the dissolved-solids concentration of the water in the main zone to the concentrations in this area during 1987-88.

At the western edge of the coastal area, average dissolved-solids concentration exceeded $8,000 \mathrm{mg} / \mathrm{L}$ in the shallow zone and $4,300 \mathrm{mg} / \mathrm{L}$ in the main zone. Oxygen-18 isotope data indicate that water from the main zone was heavier (less negative) near the coast than in the western plain. This suggests that isotopically heavier seawater or irrigation-return water in 


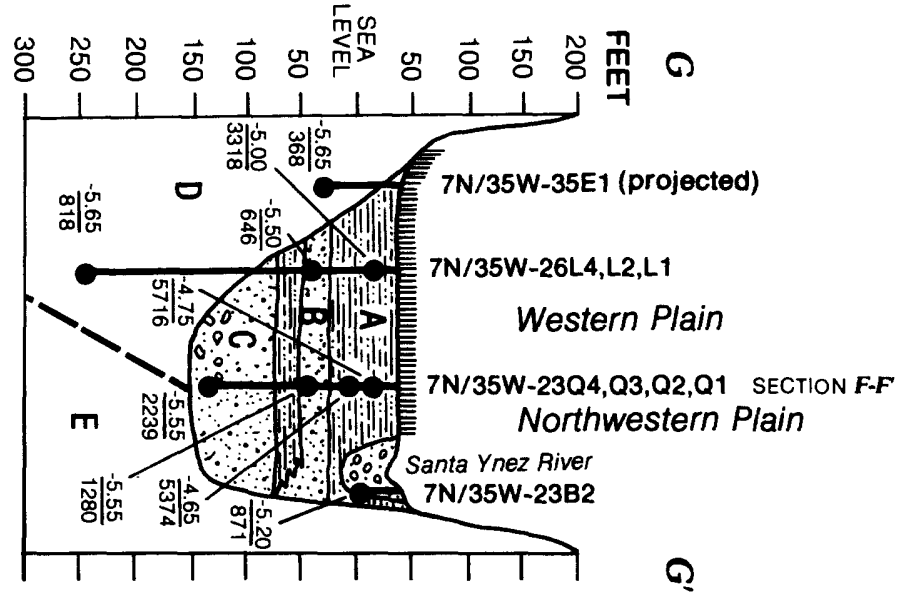

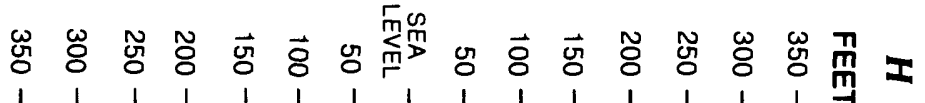

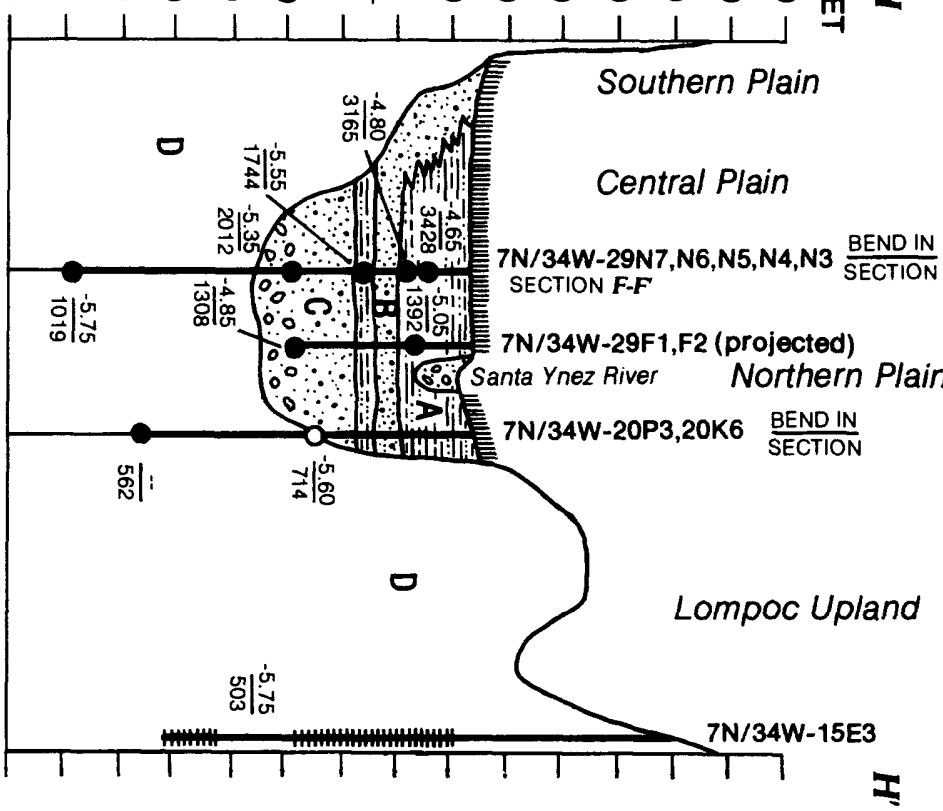

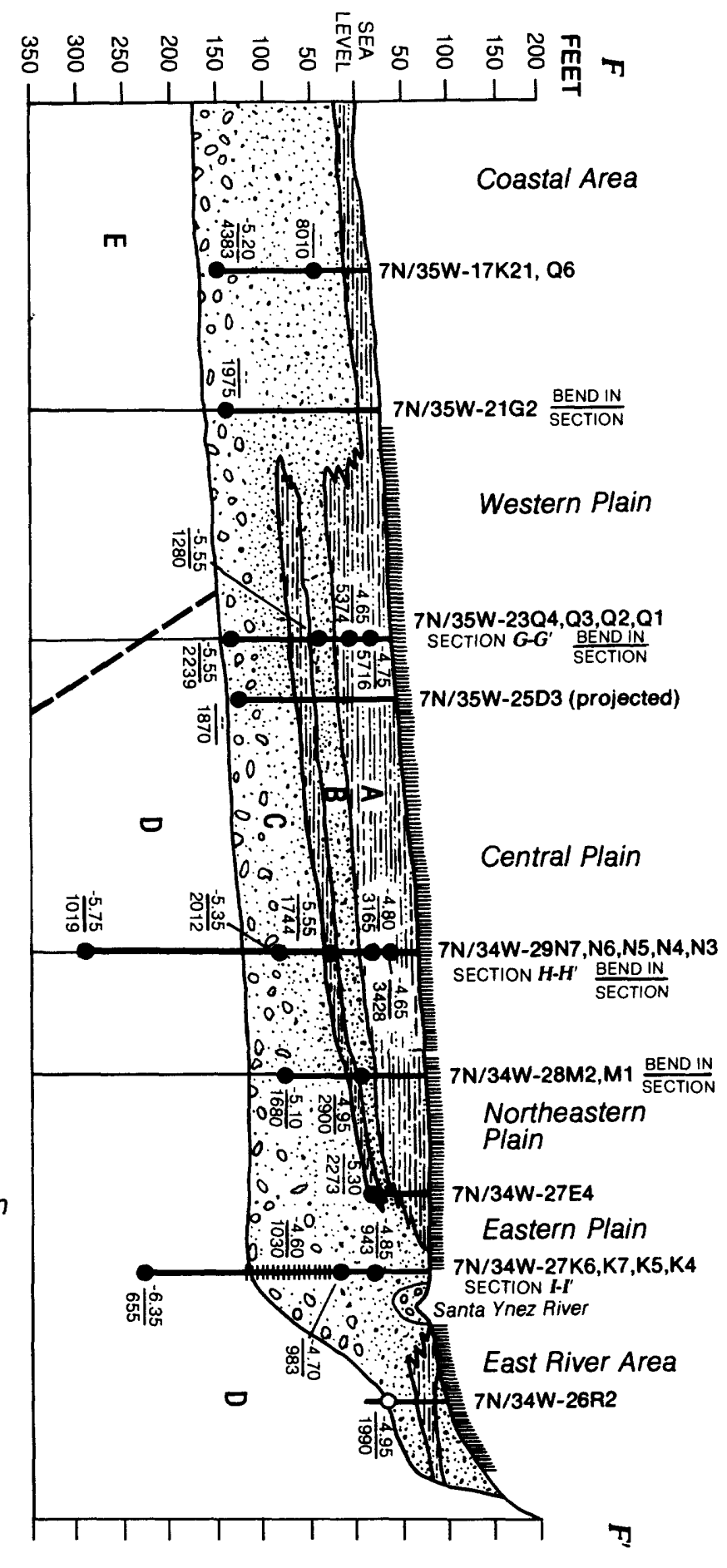




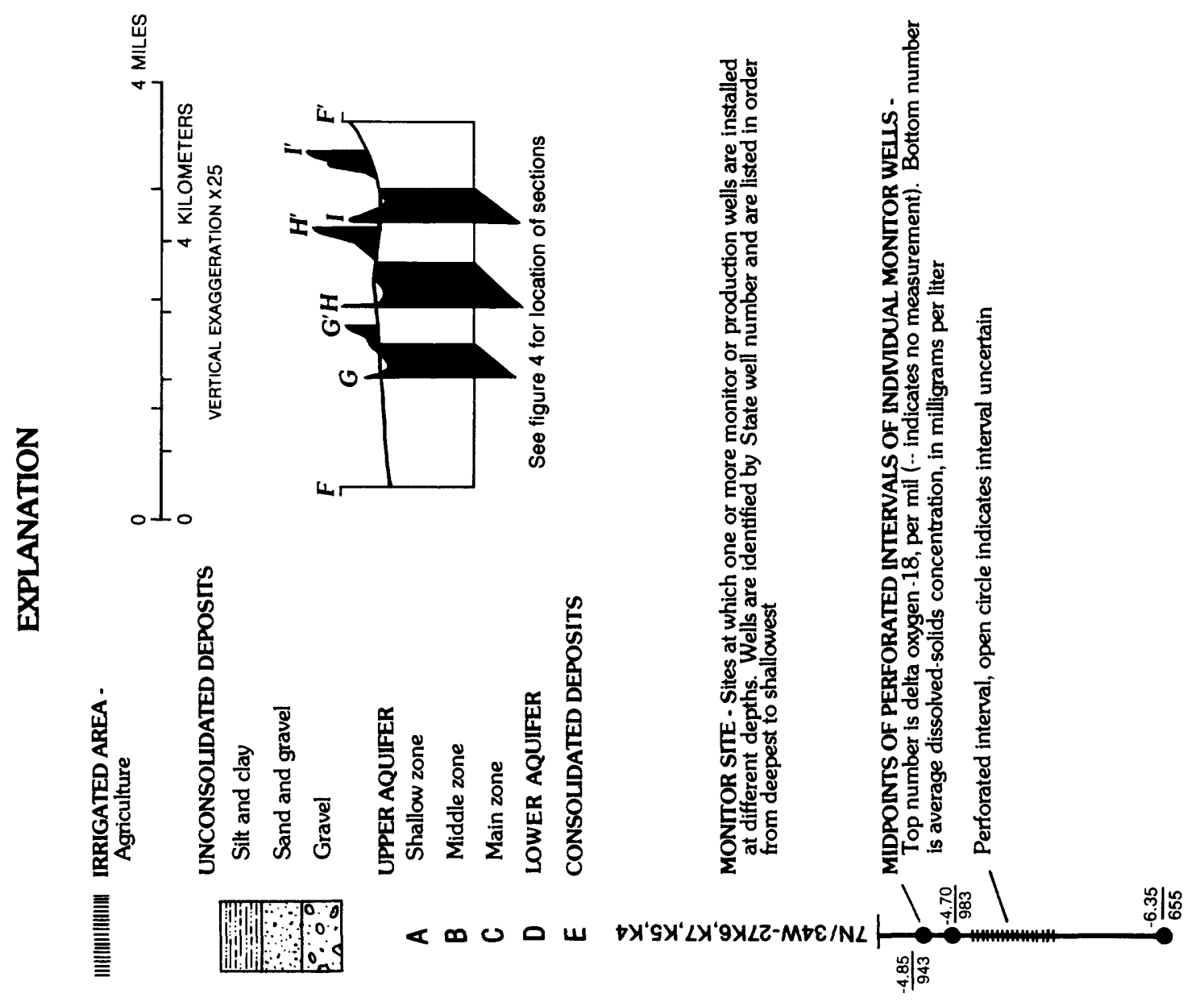

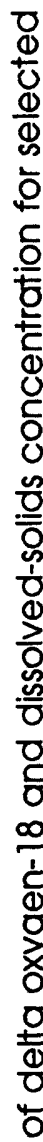

은

으드

兘

c․ㅛ

든.

응 음

品

엉

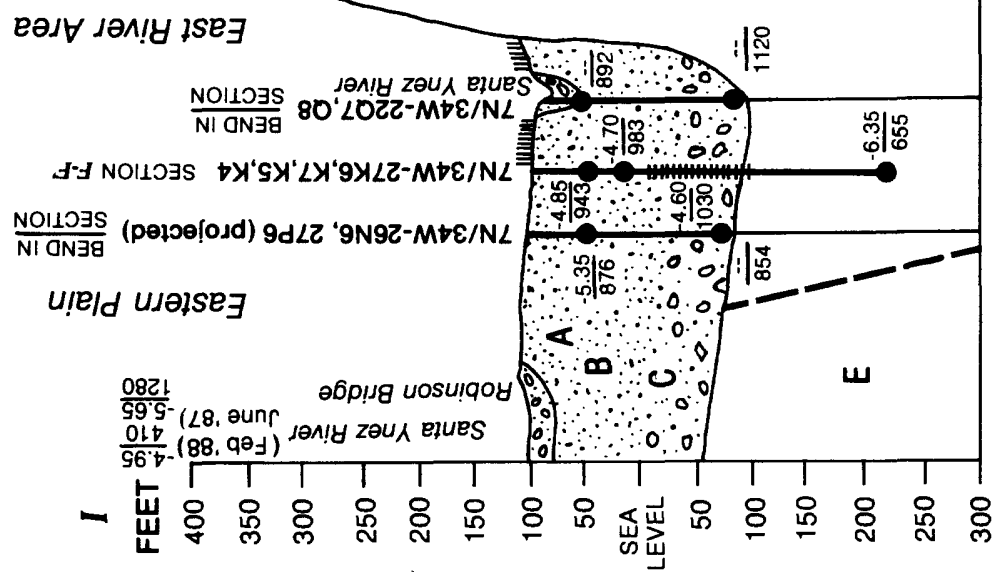

응 둗

는 음

응

هㄹㄹ

ఫ్

잉

Ф

(1)

13
+3

흔

온 
the shallow zone, rather than the isotopically lighter (more negative) water from the underlying consolidated rocks, affected the chemical quality of water in the shallow and main zones. Water from both zones was dominated by sodium and chloride in concentrations greater than those found in samples from the shallow zone beneath irrigated fields, which further suggests that seawater was the source of the high dissolved-solids concentration. Lateral migration of seawater into the upper aquifer was unlikely because hydraulic head in the shallow and main zones (fig. 9) were significantly above sea level and thus the direction of ground-water movement was toward the Pacific Ocean. However, vertical migration of seawater from the overlying estuary was possible because the silt and clay layers of the shallow zone are relatively thin near the coast (fig. 14), and the difference in hydraulic head between zones indicates that water could have moved downward from the shallow zone to the main zone (fig. 9).

\section{SEASONAL CHANGES}

Wells in the monitoring network were sampled several times during 1987-88 to determine seasonal changes in the chemical quality of ground water. Most of the sampling was concentrated at four cluster sites (sites at which three or more monitor wells were installed at different depths) (fig. 8). Dissolved-solids concentrations from the cluster sites in the central plain are shown in figure 15.

Dissolved-solids concentration in water from the middle and main zones of the upper aquifer and from the lower aquifer did not change significantly at any of the cluster sites. However, as shown in figure 15, changes in the dissolved-solids concentration were significant in the shallow zone. These changes were believed to be the result of irrigation and planting practices on cultivated fields adjacent to the cluster sites. Additional water-quality data would need to be collected to determine if these changes were cyclic or if they were part of a long-term trend.

\section{LONG-TERM CHANGES}

\section{Upper Aqulfer}

Shallow zone--Long-term water-quality data were scarce for the shallow zone because few wells have been perforated solely within this zone. However, available data indicate that prior to irrigated farming, the water quality of the shallow zone in the eastern plain probably was similar to that of the main zone

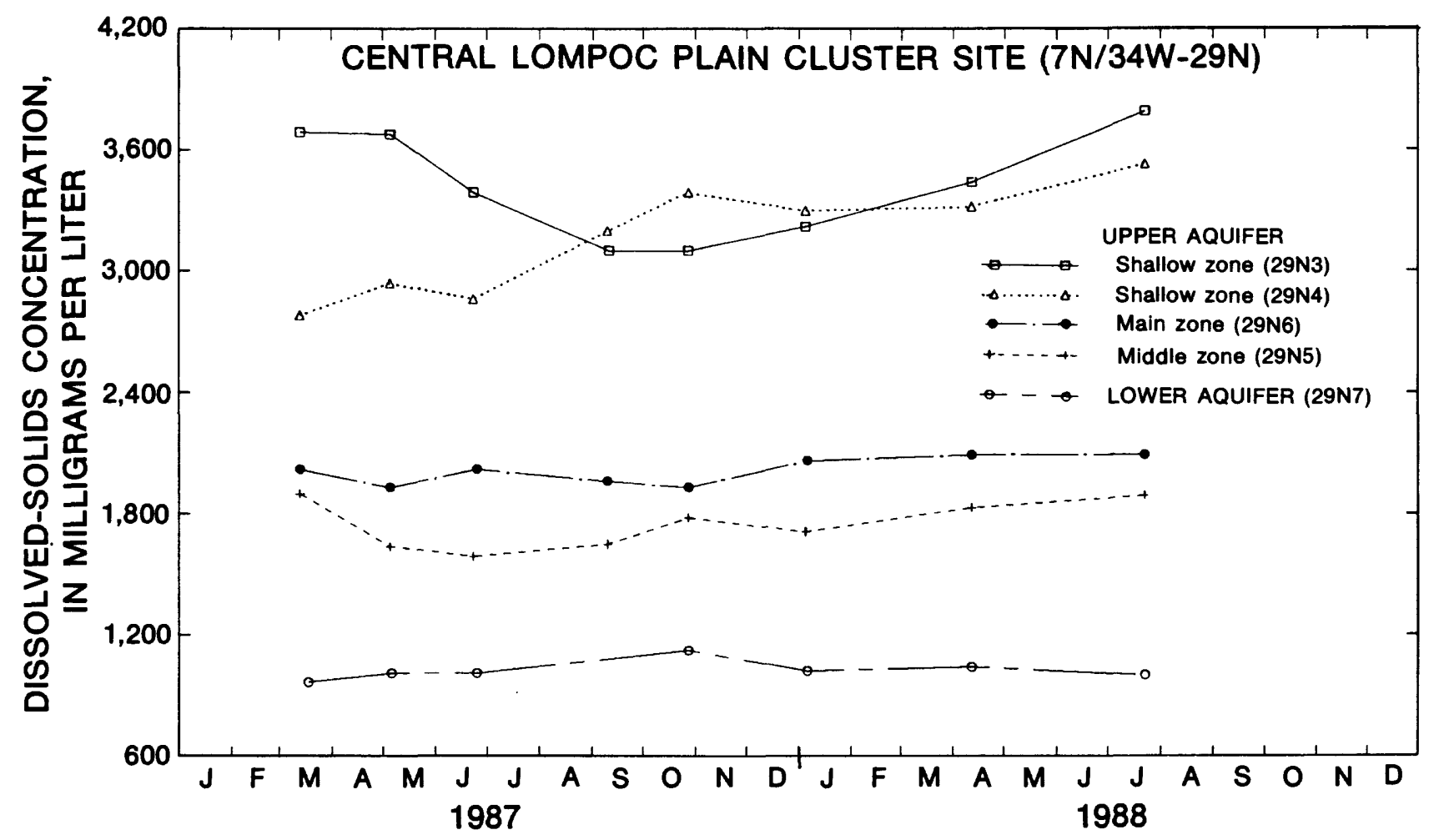

Figure 15. Dissolved-solids concentration of samples from wells at the central Lompoc plain cluster site. (See figure 8 for location of wells.) 
(Miller, 1976, p. 65). Miller (1976, p. 65) reported that four samples collected in 1935 from the shallow zone in the eastern plain contained from 860 to $1,350 \mathrm{mg} / \mathrm{L}$ of dissolved solids. Ground-water samples collected from the shallow zone in the eastern plain during this study indicate that average dissolved-solids concentration was about $950 \mathrm{mg} / \mathrm{L}$ (fig. 12). In the northeastern plain, the concentration of dissolved-solids in the shallow zone prior to irrigated farming also was similar to concentrations measured in 1988, although markedly higher than in the eastern plain. A ground-water sample collected in 1941 from well $7 \mathrm{~N} / 34 \mathrm{~W}-28 \mathrm{~F} 1$ in the northeastern plain had a specific conductance (which provides an indication of ionic concentration) of 5,620 $\mu \mathrm{S} / \mathrm{cm}$ (microsiemens per centimeter at $25^{\circ} \mathrm{C}$ ) compared to an average specific conductance of 4,200 $\mu \mathrm{S} / \mathrm{cm}$ for samples collected in 1987-88.

Available data from the shallow zone in the central plain, however, indicate a significant increase in dissolved solids from 1948 to 1988 . A sample collected in 1948 from well 7N/34W-31C3 in the central plain had a specific conductance of $1,700 \mu \mathrm{S} / \mathrm{cm}$. Samples from this same area in 1988 had specific conductance values greater than $4,400 \mu \mathrm{S} / \mathrm{cm}$, indicating more than a twofold increase in dissolved solids between 1948 and 1988.

Historical data from the western plain indicate that the shallow zone in this area contained poor-quality ground water prior to significant irrigated farming. A sample collected in 1943 from well $7 \mathrm{~N} / 35 \mathrm{~W}-23 \mathrm{~J} 3 \mathrm{had}$ a specific conductance of $4,530 \mu \mathrm{S} / \mathrm{cm}$. A possible explanation for the poor-quality ground water prior to significant irrigated farming is that this part of the plain formerly was a marshland. Water discharging to the marshland resulted in the evaporation and accumulation of salts in the fine-grained deposits of the shallow zone. Samples collected during this study, however, indicate that the quality of water in the shallow zone has continued to deteriorate from 1943 to 1988 . Samples taken from wells $7 \mathrm{~N} / 35 \mathrm{~W}-23 \mathrm{Q} 1$ and $7 \mathrm{~N} / 35 \mathrm{~W}-23 \mathrm{Q} 2$ in 1987-88 had specific-conductance values and dissolvedsolids concentrations in excess of $6,000 \mu \mathrm{S} / \mathrm{cm}$ and $5,200 \mathrm{mg} / \mathrm{L}$, respectively. In the western plain, the most likely sources of the continued water-quality degradation in the shallow zone were irrigation-return flow that has been enriched with dissolved solids by evaporation, dissolution of soluble salts (Miller, 1976, p. 65), and accumulation of salts from upgradient fields.

Middle zone.--All but one of the wells perforated in the middle zone that were sampled for chemical analysis in 1987-88 were drilled by the U.S. Geological Survey. Historical water-quality data for the middle zone generally were not available. Relatively low dissolved-solids concentrations during 1987-88 suggest that only slight changes have occurred in the water quality of the middle zone in most areas. However, in the northeastern plain, dissolved-solids concentrations were considerably higher; the higher concentrations suggest that leaching of water from the shallow zone probably had degraded the water quality of the middle zone.

Maln zone.--Because of the dependence on the main zone as a source for irrigation water, waterquality data have been collected over a long period of time at several locations on the Lompoc plain. Graphs of changes in dissolved-solids concentration with time are shown in figure 16. The graphs include data from more than one well at a particular location in the Lompoc area. The inclusion of data from adjacent wells that were perforated in the same zone enables the presentation of a longer, more complete history of each area.

Dissolved-solids concentrations of samples from the city of Lompoc municipal supply wells closest to the Santa Ynez River (7N/34W-27Q2, 34A4, and 34B1) had increased only slightly since the wells were first sampled in the early to mid-1960's (fig. 16A). Concentrations of dissolved solids in samples from these wells were about $1,000 \mathrm{mg} / \mathrm{L}$ in 1987-88 and probably reflected the average of the dissolved-solids concentrations of the Santa Ynez River during low flows ( 800 to $1,300 \mathrm{mg} / \mathrm{L}$ ) and high flows (350 to $800 \mathrm{mg} / \mathrm{L}$ ) (fig. 17). (Flows with discharges greater than $100 \mathrm{ft}^{3} / \mathrm{s}$ were considered here to be high flows.) Chemical analyses of water from wells indicate that dissolved-solids concentration in the eastern plain increased from about $900 \mathrm{mg} / \mathrm{L}$ in 1935 (well 7N/34W-27E1 in fig. 16A) to almost 1,500 $\mathrm{mg} / \mathrm{L}$ in 1988. This increase in dissolved-solids concentration might have been partly a result of the construction of Bradbury Dam to form Lake Cachuma in 1953. As shown in figure 7, the frequency of high flows (equal to or greater than $100 \mathrm{ft}^{3} / \mathrm{s}$ or 72,400 acre-ft/yr) measured at the Santa Ynez River near the Narrows decreased from about 22 percent prior to 1953 to less than 10 percent since the construction of Bradbury Dam. Figure 17 shows that the concentration of dissolved solids in river-water samples collected during 1978-88 was inversely related to discharge in the Santa Ynez River. Because the regulation of the Santa Ynez River has decreased the frequency of high flows, the average dissolved-solids concentration in the water that recharged the main zone from this source undoubtedly has increased. However, surface-water-quality data prior to 1978 were not available to substantiate this assumption. 


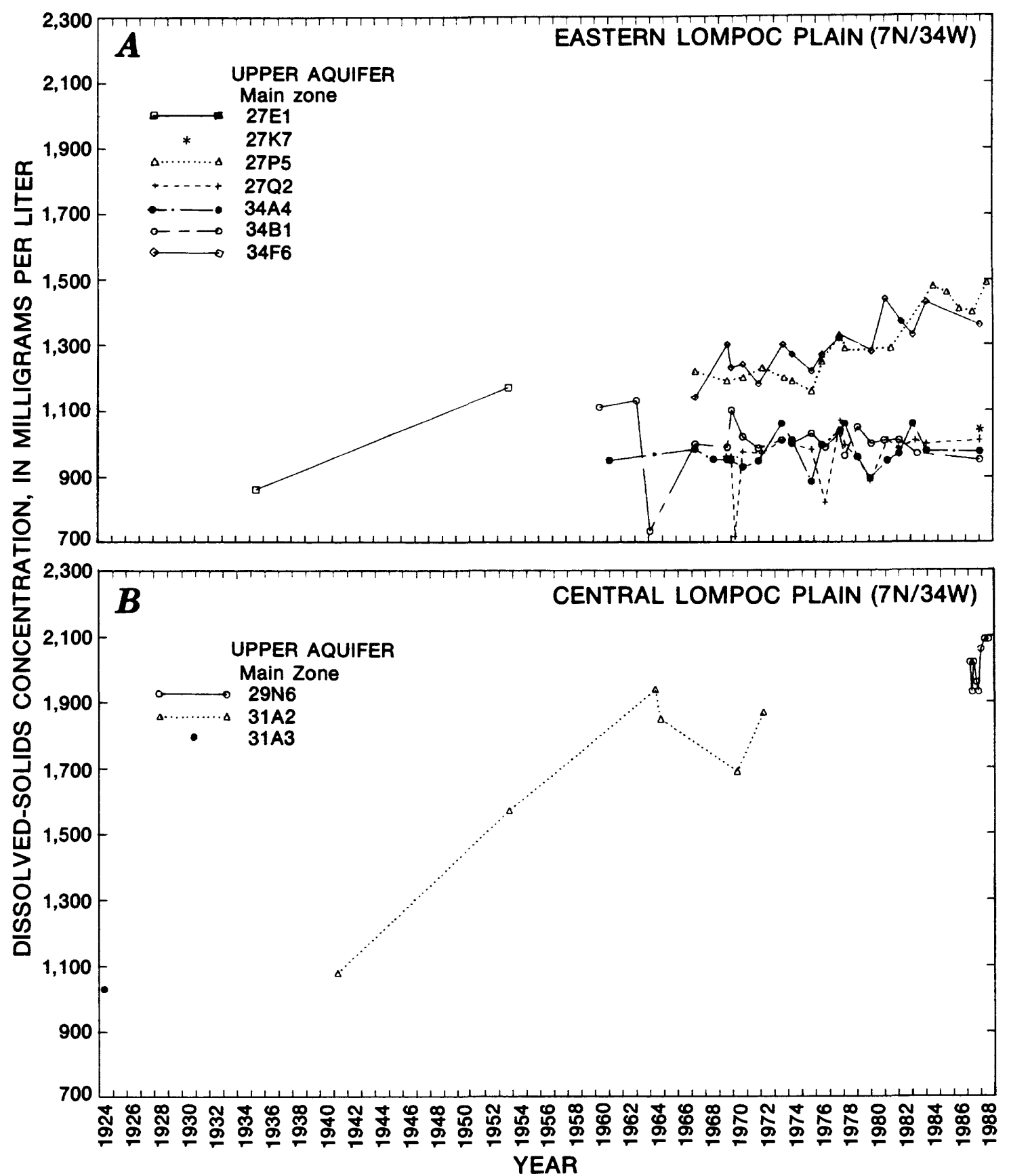

Figure 16. Dissolved-solids concentration of samples from selected wells, 1924-88. (See figure 8 for location of wells.)

Samples from the municipal supply wells farthest from the Santa Ynez River (wells 7N/34W-27P5 and 34F6) indicate an increase of almost $300 \mathrm{mg} / \mathrm{L}$ in dissolved-solids concentration from the early 1960's to 1988. Ground-water movement in the shallow and main zones in 1988 (fig. 9) indicate that the cone of depression created by the city of Lompoc municipal supply wells induced the migration of water containing high concentrations of dissolved solids from the northeastern plain (fig. 12) toward the municipal supply wells. This migration probably caused the trend of deteriorating water quality observed in the northern municipal supply wells.

Dissolved-solids concentration increased dramatically in the main zone in the central and westem plain from the late 1950's to the early 1960's (fig. $16 B, 16 C)$. In both areas, dissolved-solids concentration increased from less than $1,000 \mathrm{mg} / \mathrm{L}$ to greater than $2,000 \mathrm{mg} / \mathrm{L}$. Since the 1960 's, there has been 


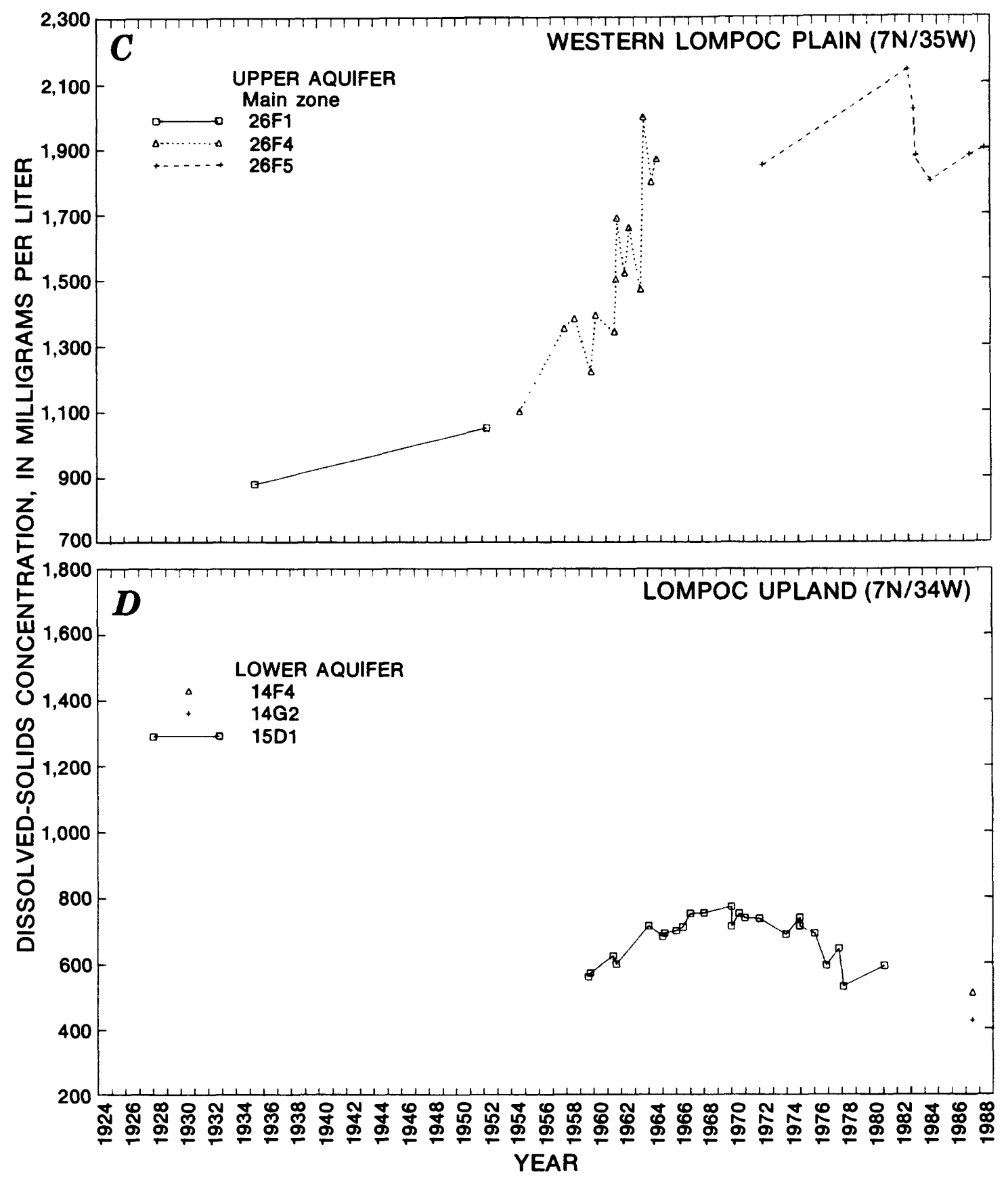

Figure 16. Continued.

only a slight increase in dissolved-solids concentration. Comparison of a dissolved-solids concentration map prepared by Miller (1976, p. 46) for the main zone in 1972 with the map presented in this report for 1987-88 data (fig. 12) indicates that the maps are almost identical over the western two-thirds of the Lompoc plain.

Dissolved-solids concentrations increased in the late 1950's in the central plain, and to a lesser degree in the western plain, because irrigation and municipal pumping in the eastern plain intercepted a large percentage of the recharge from the Santa Ynez River. Consequently, leakage of water of high dissolved-solids concentration from the shallow zone in the eastern plain, where the silt and clay layers are less extensive, became a significant source of recharge to the main zone in the western two-thirds of the Lompoc plain. Dissolved-solids concentrations have remained relatively unchanged since the 1960's because pumpage from the Lompoc plain has been relatively constant since the late 1950's (fig. 6). Therefore, the chemical quality of the main zone appears to have reached a steady-state condition. 


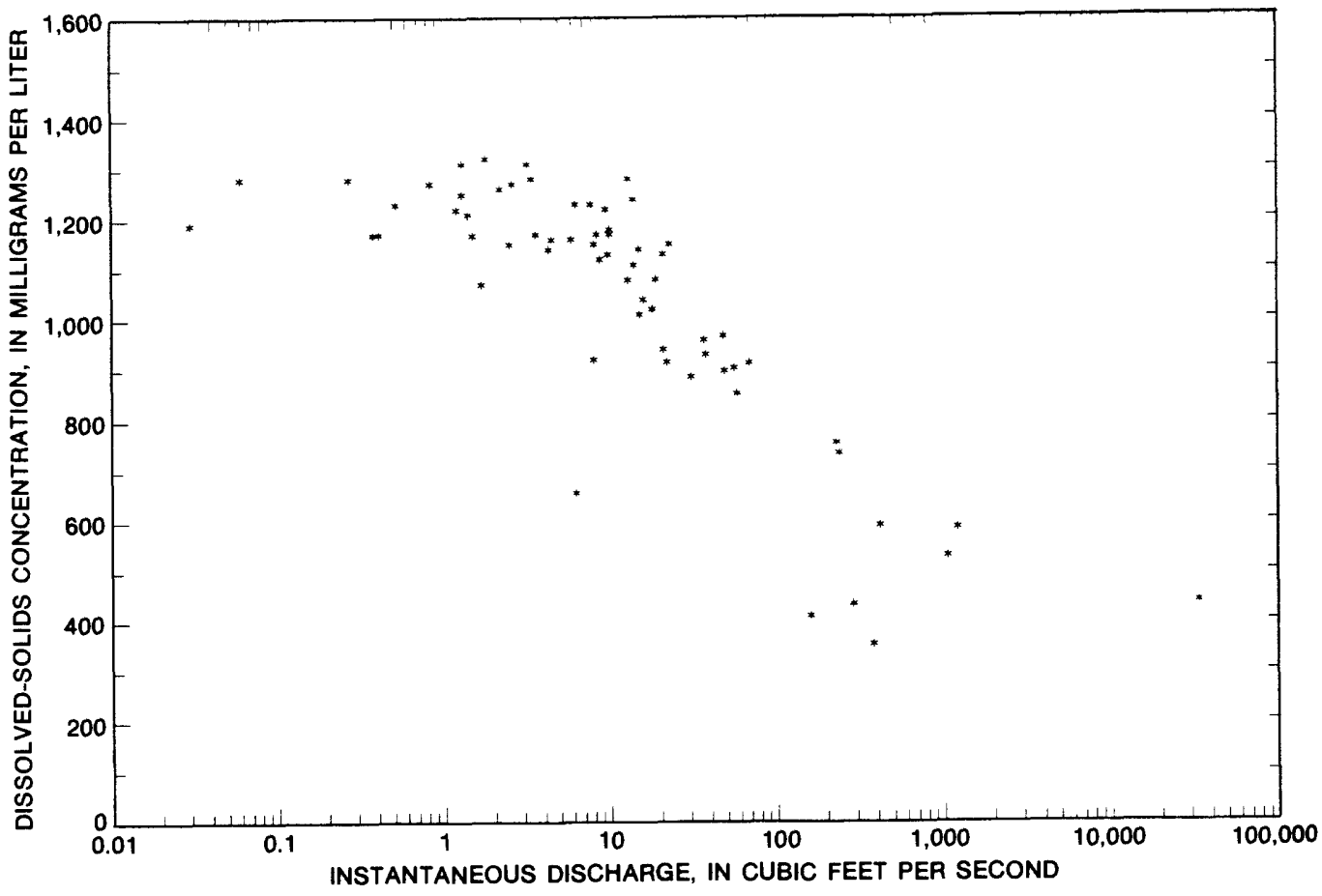

Figure 17. Instantaneous discharge and dissolved-solids concentration, Santa Ynez River at Narrows, near Lompoc (station 11133000), 1978-88). (Dissolved-solids concentration calculated from solids residue on evaporation at 180 degrees Celsius.)

\section{Lower Aqulfer}

Available water-quality data for the lower aquifer in the Lompoc upland indicate that dissolved-solids concentrations have not changed significantly since the early 1960's (fig. 16D). This would be expected because there has been no change in the source of recharge for this area and because variation in water quality from precipitation has been negligible. Although no historical data were available for the lower aquifer beneath the plain, it is probable that there has been little change in the ground-water quality.

\section{CONCLUSIONS}

Ground water historically has been the main source for agricultural, municipal, and military water supply in the Lompoc area of the Santa Ynez River basin. Previous studies have concluded that the quality of ground water has been degraded to levels that do not meet water-quality standards recommended by the U.S. Environmental Protection Agency. These studies suggest that recharge by irrigation water is the principal cause of the deterioration. As the demand for ground water in the Lompoc area has increased, State and local regulatory agencies and water users have realized a need to reverse the trend of continued deterioration of groundwater quality. This report describes the ground-water hydrology and quality of the Lompoc area and evaluates possible sources for ground-water quality degradation in the Lompoc plain.

The Lompoc area is on the west coast of Santa Barbara County and includes the Lompoc plain, the Lompoc terrace, and the Lompoc upland. The Lompoc plain, terrace, and upland are bordered on the north by the Purisima Hills, on the east by the Santa Rita Hills, on the south by the foothills of the Santa Ynez Mountains, and on the west by the Pacific Ocean. Two principal aquifers comprise the groundwater system in the Lompoc area. The upper aquifer 
contains the shallow, middle, and main zones. The main zone is the principal water-bearing unit in the Lompoc plain. The lower aquifer is the principal water-bearing unit in the Lompoc upland and Lompoc terrace.

The main zone of the upper aquifer was confined or partly confined in the central and western plains by fine-grained deposits of low permeability in the overlying shallow and middle zones. Downward leakage of ground water from the shallow and middle zones was limited by these fine deposits. In the eastern plain, near the Santa Ynez River, and in the northwestern plain, the fine deposits are less continuous or absent; as a result, ground water moved freely between the shallow, middle, and main zones. In the southern plain, the main zone itself is absent, and the fine deposits in the shallow and middle zones are also less continuous or absent. Thus, ground water moved freely between the shallow and middle zones of the upper aquifer and the lower aquifer in the southern plain.

Beneath the irrigated or formerly irrigated fields in the northeastern plain, average dissolved-solids concentration was greater than $2,000 \mathrm{mg} / \mathrm{L}$. The source of the high dissolved-solids concentrations in the middle zone in the northeastern plain was downward leakage from the shallow zone. In this area, silt and clay deposits in the shallow and middle zones are less extensive than in the central and western plain, and water moved more freely between the zones. As the ground water of high dissolvedsolids concentration in the northeastern plain moved downgradient beneath the central and western plain, it was diluted by the water containing low concentrations of dissolved solids from the southern edge of the plain. The presence of water of low dissolvedsolids concentration in the middle zone indicated that little, if any, of the water of high dissolved-solids concentration from the shallow zone recharged the middle zone in the western plain.

Dissolved-solids concentrations in the main zone beneath the eastern plain, near the Santa Ynez River, increased only slightly from the early 1960's to 1988 . Concentrations of dissolved solids in this area were about $1,000 \mathrm{mg} / \mathrm{L}$ in 1988 and probably reflected the average dissolved-solids concentration of the Santa Ynez River during low flows ( 800 to $1,300 \mathrm{mg} / \mathrm{L}$ ) and high flows (350 to $800 \mathrm{mg} / \mathrm{L}$ ).
Dissolved-solids concentrations in the main zone beneath the eastern plain, near the northeastern plain boundary, increased from about $1,000 \mathrm{mg} / \mathrm{L}$ in the early 1960 's to about $1,500 \mathrm{mg} / \mathrm{L}$ in 1988 . A cone of depression created by municipal pumping from the main zone in the eastern plain has induced the migration of water containing high concentrations of dissolved solids from the middle zone in the northeastern plain toward the municipal supply wells. This migration probably has caused the deterioration of water quality in this area. Also, this increase in dissolved-solids concentration might be partly a result of the construction of Bradbury Dam to form Lake Cachuma in 1953. Since the completion of the dam, the regulation of discharge in the Santa Ynez River has reduced the frequency of high flows that contained lower dissolved-solids concentrations ( 350 to $800 \mathrm{mg} / \mathrm{L}$ ). Consequently, the average dissolvedsolids concentration in the water that recharged the main zone from this source has increased.

Dissolved-solids concentrations increased in the main zone in the central and western plains from the late 1950's to the early 1960's. In both areas, dissolved-solids concentrations increased from less than $1,000 \mathrm{mg} / \mathrm{L}$ to greater than $2,100 \mathrm{mg} / \mathrm{L}$. These concentrations increased in the central plain, and to a lesser degree in the western plain, because irrigation and municipal pumping in the eastem plain during the late 1950's intercepted a large percentage of the recharge from the Santa Ynez River. Consequently, leakage of water of high dissolved-solids concentration from the shallow and middle zones in the northeastern plain became a significant source of recharge to the main zone in the western two-thirds of the Lompoc plain. Dissolved-solids concentrations have remained relatively unchanged from the 1960's to 1988 because pumpage from the Lompoc plain has been relatively constant since the late 1950's. Therefore, the chemical quality of the main zone in the central and western plain appears to have reached a steady-state condition.

During 1988, the dissolved-solids concentration in the main zone was diluted by as much as $300 \mathrm{mg} / \mathrm{L}$ by upward leakage of water of lower dissolved-solids concentration from the underlying lower aquifer near the boundary of the central and western plain. Near the boundary of the western plain and coastal area, the lower aquifer is less continuous or absent, and the main zone overlies consolidated rocks that contained water of high dissolved 
solids concentrations (greater than $11,000 \mathrm{mg} / \mathrm{L}$ ). The increase in dissolved solids in this area probably was the result of upward migration of water from the underlying consolidated rocks.

In the western part of the coastal area, dissolvedsolids concentrations exceeded $4,000 \mathrm{mg} / \mathrm{L}$ in the main zone in 1988. Water-quality and water-level data indicate that downward leakage of seawater from the overlying estuary, rather than lateral migration of seawater from the Pacific Ocean, was the source of ground-water degradation in this area.

\section{REFERENCES CITED}

Ahlroth, J.A., Lawrence, C.H., MacDonald, P.S., and Wasserman, C.B., 1977, Adequacy of the groundwater resources in the Lompoc area: Santa Barbara County Water Agency, $38 \mathrm{p}$.

Ayers, R.S., and Westcott, D.W., 1976, Water quality for agriculture: Food and Agriculture Organization of the United Nations, no. 29, 97 p.

Berenbrock, Charles, 1988, Ground-water quality in the Lompoc plain, Santa Barbara County, California: U.S. Geological Survey Water-Resources Investigations Report, 87-4101, 54 p.

California Department of Public Health, Sanitary Engineering Section, 1977, California domestic water quality and monitoring regulations: California Health and Safety Code and California Administrative Code, Title 22, p. 1701-1719.

California Department of Water Resources, 1964, Names and areal code numbers of hydrologic areas in the southern district, $67 \mathrm{p}$.

----1987, Southern central coast land use survey, 1985, $25 \mathrm{p}$.

Camp Dresser and McKee, Inc., 1986, City of Lompoc water system evaluation and rate study: Walnut Creek, California, Consulting Engineers, 127 p.

Craig, H., 1961, Isotopic variations in meteoric waters: Science, v. 133, p. 1702-1703.

Dibblee, T.W., Jr., 1950, Geology of southwestern Santa Barbara County, California, Point Arguello, Lompoc, Point Conception, Los Olivos, and Gaviota quadrangles: California Division of Mines Bulletin 150, $95 \mathrm{p}$.

Evenson, R.E., 1964, Suitability of irrigation water and changes in ground-water quality in the Lompoc subarea of the Santa Ynez River basin, Santa Barbara County, California: U.S. Geological Survey Open-File Report, $62 \mathrm{p}$.

--1966, Hydrologic inventory of the Lompoc subarea, Santa Ynez River basin, Santa Barbara County, California, 1957-62, with a section on Perennial supply by R.E. Evenson and G.F. Worts, Jr.: U.S. Geological Survey Open-File Report, 27 p.

Fournier, R.D., and Thompson, J.M., 1980, The recharge area for the Coso, California, geothermal system deduced from $\delta \mathrm{D}$ and $\delta^{18} \mathrm{O}$ in thermal and non-thermal waters in the region: U.S. Geological Survey Open-File Report $80-454,27$ p.
Hall, A.H., Jr., 1978, Origin and development of the LompocSanta Maria pull-apart basin and its relation to the San Simeon-Hosgri strike-slip fault, western California: California Division of Mines and Geology Special Report 137, p. 25-31.

Hem, J.D., 1985, Study and interpretation of the chemical characteristics of natural water: U.S. Geological Survey Water-Supply Paper 2254, 263 p.

Lewis, R.E.. 1969, Ground water in Santa Barbara County, California, spring 1967 to spring 1968: U.S. Geological Survey Open-File Report [69-149], 30 p.

Miller, G.A., 1976, Ground-water resources in the Lompoc area, Santa Barbara County, California: U.S. Geological Survey Open-File Report 76-183, 78 p.

Muir, K.S., and Fenzel, F.W., 1968, Ground water in Santa Barbara County, California, spring 1966 to spring 1967: U.S. Geological Survey Open-File Report, 36 p.

National Oceanic and Atmospheric Administration, 1976-88, Climatological data--California: annual summaries, v. 80-92.

Stiff, H.A., Jr., 1951, The interpretation of chemical water analysis by means of patterns: Journal of Petroleum Technology, v. 3, n. 10, p. 15-17.

Sylvester, A.G., and Darrow, A.C., 1979, Structure and neotectonics of the western Santa Ynez fault system in southern California: Tectonophysics, v. 52, p. 389-405.

Upson, J.E., and Thomasson, H.G., Jr., 1951, Geology and water resources of the Santa Ynez River basin, Santa Barbara County, California: U.S. Geological Survey Water-Supply Paper 1107, 194 p.

U.S. Bureau of Reclamation, 1964-75, Progress reports on investigations, measurements, and studies during water years 1962-73, Santa Ynez River, Cachuma Project, $17 \mathrm{p}$.

U.S. Department of Agriculture, Weather Bureau, 1910-30, Climatic summary of the United States: section 17-central Califormia, $64 \mathrm{p}$.

U.S. Department of Commerce, Weather Bureau, 1954-76, Climatological data--California: Annual summaries [for 1953-75], v. 57-79.

----1958, Climatic summary of the United States--supplement for 1931 through 1952: Climatography of the United States, no. $11-4,156$ p.

U.S. Environmental Protection Agency, 1977, National interim primary drinking water regulations: U.S. Environmental Protection Agency, Office of Water Supply, EPA 570/976-003, $159 \mathrm{p}$

----1979, National secondary drinking water regulations: Federal Register, v. 44, no. 140 , July 19, 1979, p. 42195 41101.

Warner, J.W., 1971, Ground water in Santa Barbara and southern San Luis Obispo Counties, California, spring 1968 to spring 1969: U.S. Geological Survey Open-File Report [71-442], 24 p.

---1972, Ground water in Santa Barbara and southern San Luis Obispo Counties, California, spring 1969 to spring 1970: U.S. Geological Survey Open-File Report [72443], $27 \mathrm{p}$.

Wilson, H.D., Jr., 1959, Ground-water appraisal of Santa Ynez River basin, Santa Barbara County, California, 1945-52: U.S. Geological Survey Water-Supply Paper 1467, 119 p.

Woodring, W.P., and Bramlette, M.N., 1950, Geology and paleontology of the Santa Maria District, California: U.S. Geological Survey Professional Paper 222, 185 p. 
TABLES 7-10 


\section{Table 7. Well-construction data}

[Measured zone or aquifer was determined on the basis of well perforations and water quality. See plate 1 and figure 8 for well locations. State well No.: See well-numbering system in text. Altitude of land surface is in feet above sea level. Depth of well, depth drilled, and perforated interval are in feet below land surface. ft, foot. >, actual value is greater than value shown. --, no data]

\begin{tabular}{|c|c|c|c|c|}
\hline State well No. & $\begin{array}{l}\text { Altitude of } \\
\text { land surface } \\
(\mathrm{ft})\end{array}$ & $\begin{array}{l}\text { Depth of } \\
\text { well } \\
\text { (ft) }\end{array}$ & $\begin{array}{c}\text { Depth } \\
\text { drilled } \\
(\mathrm{ft})\end{array}$ & $\begin{array}{c}\text { Perforated } \\
\text { interval } \\
(\mathrm{ft})\end{array}$ \\
\hline \multicolumn{5}{|c|}{ Upper Aquifer--Shallow Zone } \\
\hline $\begin{array}{r}7 \mathrm{~N} / 34 \mathrm{~W}-22 \mathrm{~L} 2 \\
22 \mathrm{Q} 8 \\
27 \mathrm{~F} 2\end{array}$ & $\begin{array}{l}93 \\
83.5 \\
92\end{array}$ & $\begin{array}{l}60 \\
46 \\
60\end{array}$ & $\begin{array}{l}60 \\
51 \\
60\end{array}$ & $\begin{array}{r}40-60 \\
26-46 \\
--\end{array}$ \\
\hline $\begin{array}{l}27 \mathrm{~K} 4 \\
27 \mathrm{P} 6 \\
28 \mathrm{~B} 5 \\
28 \mathrm{~F} 1 \\
29 \mathrm{~F} 2 \\
29 \mathrm{~N} 3\end{array}$ & $\begin{array}{l}102.35 \\
80 \\
73.5 \\
79.07 \\
62.86 \\
67.41\end{array}$ & $\begin{array}{l}62 \\
56.5 \\
45 \\
40 \\
60.5 \\
33\end{array}$ & $\begin{array}{l}62.1 \\
56.5 \\
49 \\
-- \\
60.5 \\
33\end{array}$ & $\begin{array}{r}57-62 \\
51.5-56.5 \\
25-45 \\
-- \\
40.5-60.5 \\
28-33\end{array}$ \\
\hline $\begin{array}{l}29 \mathrm{~N} 4 \\
30 \mathrm{~L} 3^{1} \\
31 \mathrm{C} 3^{1} \\
31 \mathrm{R} 2 \\
32 \mathrm{~N} 1\end{array}$ & $\begin{array}{l}67.34 \\
59 \\
65 \\
70.35 \\
73\end{array}$ & $\begin{array}{l}60 \\
32 \\
27 \\
87.5 \\
--\end{array}$ & $\begin{array}{r}65 \\
32 \\
28 \\
110 \\
--\end{array}$ & $\begin{array}{r}55-60 \\
32 \\
27 \\
29-44 \\
--\end{array}$ \\
\hline $\begin{array}{l}33 \mathrm{E} 5 \\
35 \mathrm{~F}^{2}\end{array}$ & $\begin{array}{r}82 \\
100\end{array}$ & $\begin{array}{l}56.5 \\
112\end{array}$ & $\begin{array}{r}58 \\
140\end{array}$ & $\begin{array}{r}46.5-56.5 \\
30-54 \\
96-101\end{array}$ \\
\hline $35 \mathrm{~K} 14$ & 130 & 60 & -- & - \\
\hline $\begin{array}{r}7 \mathrm{~N} / 35 \mathrm{~W}-13 \mathrm{~N} 2^{3} \\
16 \mathrm{G} 1 \\
16 \mathrm{R} 1 \\
17 \mathrm{G} 1 \\
17 \mathrm{Q} 6 \\
23 \mathrm{~B} 2\end{array}$ & $\begin{array}{l}60 \\
18 \\
20 \\
10 \\
20 \\
30\end{array}$ & $\begin{array}{l}44 \\
46 \\
80 \\
88 \\
87 \\
80\end{array}$ & $\begin{array}{r}103 \\
46 \\
82 \\
140 \\
120 \\
80\end{array}$ & $\begin{array}{r}22-44 \\
-- \\
20-60 \\
58-78 \\
57-77 \\
20-60\end{array}$ \\
\hline $\begin{array}{l}23 \mathrm{~J}^{1} \\
23 \mathrm{Q} 1 \\
23 \mathrm{Q} 2 \\
23 \mathrm{Q} 5 \mathrm{LYS} \\
25 \mathrm{~F} 6\end{array}$ & $\begin{array}{l}43.43 \\
37.11 \\
37.22 \\
37 \\
47\end{array}$ & $\begin{array}{l}33 \\
27.5 \\
51 \\
11 \\
19.4\end{array}$ & $\begin{array}{l}33 \\
27.5 \\
51 \\
-- \\
--\end{array}$ & $\begin{array}{r}33 \\
23-27.5 \\
46-51 \\
10.8-11 \\
--\end{array}$ \\
\hline $\begin{array}{l}25 F 7^{1} \\
26 \mathrm{~L}^{1} \\
26 \mathrm{~L} 3 \mathrm{LYS}\end{array}$ & $\begin{array}{l}47 \\
36.09 \\
36\end{array}$ & $\begin{array}{l}30 \\
22.5 \\
8\end{array}$ & $\begin{array}{l}32 \\
22.5 \\
16\end{array}$ & $\begin{array}{r}30 \\
17.5-22.5 \\
7.8-8\end{array}$ \\
\hline
\end{tabular}

Upper Aquifer--Middle Zone

\begin{tabular}{rcccr}
\hline 7N/34W- 26R2 & 114 & - & -- & -- \\
$27 \mathrm{E} 4$ & 89 & 58.5 & 60 & $48.5-58.5$ \\
$27 \mathrm{~K} 5$ & 102.59 & 97.5 & 97.5 & $92.5-97.5$ \\
$27 \mathrm{~N} 6$ & 79 & 95.5 & 95.5 & $85.5-95.5$ \\
$28 \mathrm{M} 1$ & 78 & 72 & 77 & $62-72$ \\
$28 \mathrm{Q} 1$ & 70 & 67 & 70 & $57-67$ \\
$29 \mathrm{H} 3$ & 71.17 & 75 & 80 & $65-75$
\end{tabular}

Footnotes at end of table. 
Table 7. Well-construction data-Continued

\begin{tabular}{rlccr}
\hline State well No. & $\begin{array}{c}\text { Altitude of } \\
\text { land surface } \\
(\mathrm{ft})\end{array}$ & $\begin{array}{c}\text { Depth of } \\
\text { well } \\
(\mathrm{ft})\end{array}$ & $\begin{array}{c}\text { Depth } \\
\text { drilled } \\
(\mathrm{ft})\end{array}$ & $\begin{array}{c}\text { Perforated } \\
\text { interval } \\
(\mathrm{ft})\end{array}$ \\
\hline UN/34W- 29L1 & \multicolumn{2}{c}{ Upper Aquifer--Middle Zone--Continued } \\
$29 \mathrm{N5}$ & 72 & 85 & -- & -- \\
$7 \mathrm{~N} / 35 \mathrm{~W}-23 \mathrm{Q} 3$ & 67.36 & 95 & 100 & $90-95$ \\
$26 \mathrm{~L} 2$ & 37.1 & 82.5 & 82.5 & $77.5-82.5$ \\
& 35.77 & 82 & 82 & $77-82$ \\
\hline
\end{tabular}

\begin{tabular}{|c|c|c|c|c|}
\hline \multicolumn{5}{|c|}{ Upper Aquifer--Main Zone } \\
\hline $7 \mathrm{~N} / 34 \mathrm{~W}-19 \mathrm{~J} 1$ & 61 & 186 & 186 & $\begin{array}{l}130-154 \\
159-165\end{array}$ \\
\hline $22 \mathrm{Q} 7$ & 83.5 & 185 & 189 & $165-185$ \\
\hline $26 \mathrm{~N} 6$ & 106 & 140 & 149 & $120-140$ \\
\hline $27 \mathrm{E} 1$ & 87 & 158 & 158 & -- \\
\hline $27 \mathrm{~F} 1$ & 94 & 170 & 185 & $105-170$ \\
\hline $27 \mathrm{~F} 4$ & 96.79 & 172 & 178 & $110-172$ \\
\hline $27 \mathrm{G} 5$ & 100 & 190 & 216 & $102-190$ \\
\hline $27 \mathrm{~K} 7$ & 98.63 & 175 & 195 & $95-165$ \\
\hline $27 N 5$ & 85.71 & 195 & 200 & $105-180$ \\
\hline $27 \mathrm{P} 5$ & 92.35 & 172 & 172 & $100-172$ \\
\hline 27Q2 & 98.97 & 185 & 190 & $95-175$ \\
\hline $28 \mathrm{~B} 4$ & 73.5 & 124 & 129 & $114-124$ \\
\hline $28 \mathrm{M} 2$ & 78 & 162.5 & 167 & $142.5-162.5$ \\
\hline $29 \mathrm{~F} 1$ & 62.67 & 164.5 & 180 & $144.5-164.5$ \\
\hline $29 \mathrm{~J} 1$ & 75 & 182 & 186 & $133-182$ \\
\hline 29N6 & 66.70 & 160 & 600 & $140-160$ \\
\hline 30L5 & 60 & 200 & -- & -- \\
\hline $31 \mathrm{~A} 2$ & 68 & 175 & 182 & -- \\
\hline $31 \mathrm{~A} 3$ & 67 & -- & 160 & -. \\
\hline $34 \mathrm{~A} 4$ & 108.63 & 170 & 176 & $150-170$ \\
\hline $34 \mathrm{~B} 1$ & 101.52 & 192 & 195 & $96-192$ \\
\hline $34 \mathrm{~F} 6$ & 103.30 & 140 & 148 & $80-140$ \\
\hline $35 \mathrm{~K} 9^{4}$ & 101 & 124 & 128 & $52-80$ \\
\hline & & & & $112-124$ \\
\hline $7 \mathrm{~N} / 35 \mathrm{~W}-17 \mathrm{~K} 20$ & 24 & 126 & 160 & $96-116$ \\
\hline $17 \mathrm{~K} 21$ & 9 & 175 & 200 & $155-175$ \\
\hline $17 \mathrm{M} 1$ & 10 & 120 & 169 & $115-120$ \\
\hline $21 G 2$ & 20 & 180 & 205 & $150-170$ \\
\hline $22 \mathrm{H} 1$ & 36 & 170 & -- & -- \\
\hline $22 \mathrm{~J} 1$ & 32 & 180 & 185 & $133-180$ \\
\hline $23 E 2$ & 37 & 190 & 212 & $170-190$ \\
\hline $23 \mathrm{~K} 1$ & 40 & -- & -- & -- \\
\hline 23Q4 & 37.32 & 190 & 440 & $160-180$ \\
\hline
\end{tabular}

Footnotes at end of table. 
Table 7. Well-construction data-Continued

\begin{tabular}{|c|c|c|c|c|}
\hline State well No. & $\begin{array}{l}\text { Altitude of } \\
\text { land surface } \\
(\mathrm{ft})\end{array}$ & $\begin{array}{l}\text { Depth of } \\
\text { well } \\
\text { (ft) }\end{array}$ & $\begin{array}{l}\text { Depth } \\
\text { drilled } \\
\text { (ft) }\end{array}$ & $\begin{array}{l}\text { Perforated } \\
\text { interval } \\
\text { (ft) }\end{array}$ \\
\hline \multicolumn{5}{|c|}{ Upper Aquifer--Main Zone--Continued } \\
\hline $\begin{array}{r}7 \mathrm{~N} / 35 \mathrm{~W}-24 \mathrm{~J} 4 \\
24 \mathrm{~K} 5\end{array}$ & $\begin{array}{l}52 \\
51\end{array}$ & $\begin{array}{l}171 \\
172\end{array}$ & $\begin{array}{l}171 \\
174\end{array}$ & $\begin{array}{l}165-170 \\
130-135 \\
140-170\end{array}$ \\
\hline $\begin{array}{l}24 \mathrm{P} 3 \\
25 \mathrm{D} 3\end{array}$ & $\begin{array}{l}50 \\
42\end{array}$ & $\begin{array}{l}195 \\
178\end{array}$ & $\begin{array}{l}198 \\
350\end{array}$ & $\begin{array}{l}155-175 \\
168-178\end{array}$ \\
\hline $\begin{array}{l}25 \mathrm{~J} 3 \\
25 \mathrm{~F} 5 \\
26 \mathrm{~F} 1 \\
26 \mathrm{~F} 4 \\
26 \mathrm{~F} 5 \\
26 \mathrm{H} 1\end{array}$ & $\begin{array}{l}52.40 \\
47 \\
36.84 \\
35 \\
35 \\
46\end{array}$ & $\begin{array}{l}175.5 \\
175 \\
176 \\
190 \\
192 \\
177\end{array}$ & $\begin{array}{l}176 \\
184 \\
186 \\
190 \\
192 \\
180\end{array}$ & $\begin{array}{r}170-174 \\
145-175 \\
117-176 \\
- \\
151-176 \\
137-177\end{array}$ \\
\hline \multicolumn{5}{|c|}{ Lower Aquifer } \\
\hline $\begin{array}{r}6 \mathrm{~N} / 34 \mathrm{~W}-4 \mathrm{G} 4 \\
6 \mathrm{C} 1\end{array}$ & $\begin{array}{l}97.5 \\
103\end{array}$ & $\begin{array}{r}75 \\
100\end{array}$ & $\begin{array}{r}77 \\
100\end{array}$ & $\begin{array}{r}65-75 \\
88-100\end{array}$ \\
\hline $\begin{array}{r}7 \mathrm{~N} / 33 \mathrm{~W}-16 \mathrm{G} 2 \\
17 \mathrm{M} 1 \\
19 \mathrm{D} 1 \\
19 \mathrm{Q} 2\end{array}$ & $\begin{array}{l}520 \\
360 \\
270 \\
280\end{array}$ & $\begin{array}{l}410 \\
290 \\
552 \\
900\end{array}$ & $\begin{array}{r}-- \\
760 \\
900\end{array}$ & $\begin{array}{r}-- \\
-- \\
228-552 \\
320-720 \\
760-890\end{array}$ \\
\hline $\begin{array}{l}20 \mathrm{G} 3^{5} \\
21 \mathrm{G} 2 \\
28 \mathrm{D} 1 \\
28 \mathrm{D} 3\end{array}$ & $\begin{array}{l}400 \\
430 \\
355 \\
360\end{array}$ & $\begin{array}{r}511 \\
>310 \\
>277 \\
600\end{array}$ & $\begin{array}{r}-- \\
-- \\
640\end{array}$ & $\begin{array}{r}190 \\
-- \\
-- \\
440-590\end{array}$ \\
\hline $\begin{array}{r}7 \mathrm{~N} / 34 \mathrm{~W}-9 \mathrm{H} 5 \\
10 \mathrm{R} 1 \\
11 \mathrm{D} 1 \\
12 \mathrm{E} 1 \\
13 \mathrm{D} 1\end{array}$ & $\begin{array}{l}275 \\
390 \\
500 \\
386 \\
450\end{array}$ & $\begin{array}{r}853 \\
4,072 \\
3,750 \\
385 \\
3,784\end{array}$ & $\begin{array}{r}960 \\
4,072 \\
3,750 \\
385 \\
3,784\end{array}$ & $\begin{array}{r}653-853 \\
-- \\
-- \\
345-385 \\
--\end{array}$ \\
\hline $\begin{array}{l}14 \mathrm{~F} 2 \\
14 \mathrm{~F} 3 \\
14 \mathrm{~F} 4 \\
14 \mathrm{G} 2 \\
14 \mathrm{~L} 1\end{array}$ & $\begin{array}{l}268 \\
268 \\
265 \\
255 \\
250\end{array}$ & $\begin{array}{l}408 \\
397 \\
568 \\
568 \\
550\end{array}$ & $\begin{array}{r}500 \\
450 \\
580 \\
-- \\
--\end{array}$ & $\begin{array}{l}148-408 \\
169-397 \\
280-530 \\
276-550 \\
200-550\end{array}$ \\
\hline $\begin{array}{l}15 \mathrm{~B} 1 \\
15 \mathrm{D} 1 \\
15 \mathrm{D} 3 \\
15 \mathrm{E} 2 \\
15 \mathrm{E} 3\end{array}$ & $\begin{array}{l}345 \\
180 \\
180 \\
200 \\
200\end{array}$ & $\begin{array}{r}3,549 \\
790 \\
683 \\
580 \\
520\end{array}$ & $\begin{array}{r}3,549 \\
796 \\
730 \\
600 \\
--\end{array}$ & $\begin{array}{r}-- \\
450-790 \\
458-683 \\
425-580 \\
200-340 \\
420-520\end{array}$ \\
\hline
\end{tabular}

Footnotes at end of table. 
Table 7. Well-construction data-Continued

\begin{tabular}{|c|c|c|c|c|}
\hline State well No. & $\begin{array}{l}\text { Altitude of } \\
\text { land surface } \\
\text { (ft) }\end{array}$ & $\begin{array}{l}\text { Depth of } \\
\text { well } \\
\text { (ft) }\end{array}$ & $\begin{array}{l}\text { Depth } \\
\text { drilled } \\
\text { (ft) }\end{array}$ & $\begin{array}{l}\text { Perforated } \\
\text { interval } \\
\text { (ft) }\end{array}$ \\
\hline \multicolumn{5}{|c|}{ Lower Aquifer--Continued } \\
\hline $\begin{array}{r}7 \mathrm{~N} / 34 \mathrm{~W}-15 \mathrm{P} 1 \\
20 \mathrm{~K} 6 \\
20 \mathrm{P} 3 \\
22 \mathrm{~J} 6 \\
23 \mathrm{R} 2\end{array}$ & $\begin{array}{r}300 \\
75 \\
71 \\
97 \\
121\end{array}$ & $\begin{array}{r}920 \\
210 \\
320 \\
135 \\
--\end{array}$ & $\begin{array}{l}924 \\
314 \\
685 \\
135 \\
690\end{array}$ & $\begin{array}{r}200-900 \\
-- \\
260-320 \\
-- \\
--\end{array}$ \\
\hline $\begin{array}{l}24 \mathrm{~N} 1 \\
26 \mathrm{H} 3 \\
26 \mathrm{Q} 5 \\
27 \mathrm{~A} 9 \\
27 \mathrm{~K} 6\end{array}$ & $\begin{array}{l}130 \\
112.92 \\
105 \\
79 \\
98.63\end{array}$ & $\begin{array}{c}159 \\
66.9 \\
151 \\
-- \\
383\end{array}$ & $\begin{array}{r}183 \\
123 \\
157 \\
930 \\
1,025\end{array}$ & $\begin{array}{r}115-159 \\
-- \\
135-140 \\
-- \\
270-350\end{array}$ \\
\hline $\begin{array}{l}29 \mathrm{~N} 7 \\
35 \mathrm{~B} 3\end{array}$ & $\begin{array}{l}66.70 \\
95\end{array}$ & $\begin{array}{l}420 \\
137\end{array}$ & $\begin{array}{l}600 \\
340\end{array}$ & $\begin{array}{l}320-360 \\
380-400 \\
117-137\end{array}$ \\
\hline $\begin{array}{r}7 \mathrm{~N} / 35 \mathrm{~W}-26 \mathrm{~L} 4 \\
27 \mathrm{P} 1 \\
28 \mathrm{~K} 3 \\
28 \mathrm{R} 1 \\
31 \mathrm{~B} 1\end{array}$ & $\begin{array}{r}36 \\
260 \\
65 \\
120 \\
85\end{array}$ & $\begin{array}{r}299 \\
577 \\
-- \\
510 \\
472\end{array}$ & $\begin{array}{l}340 \\
677 \\
440 \\
551 \\
472\end{array}$ & $\begin{array}{r}259-299 \\
562-577 \\
-- \\
470-510 \\
--\end{array}$ \\
\hline $31 \mathrm{~J} 1$ & 160 & 591 & 625 & $\begin{array}{l}155-244 \\
571-591\end{array}$ \\
\hline $33 \mathrm{~J} 2$ & 177 & 465 & 530 & $\begin{array}{l}170-210 \\
375-465\end{array}$ \\
\hline $33 \mathrm{~J} 3$ & 220 & 460 & 660 & $\begin{array}{r}96-160 \\
428-460\end{array}$ \\
\hline $33 \mathrm{~J} 4$ & 219 & 462 & 502 & $370-462$ \\
\hline 35E1 & 52.8 & 71.5 & 72 & -- \\
\hline
\end{tabular}

${ }_{1}^{1}$ Perforated at bottom of well point.

${ }_{3}^{2}$ Upper perforations in river-channel deposits. Aquifer opposite lower perforations uncertain.

${ }^{3}$ Perforated in alluvium of tributary stream to Santa Ynez River.

${ }^{4}$ Upper perforations in river-channel deposits; lower perforations in main zone.

${ }^{5}$ Depth to bottom of perforations unknown. 


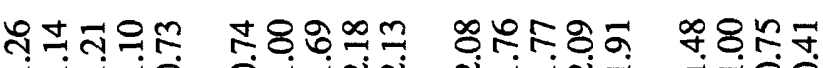

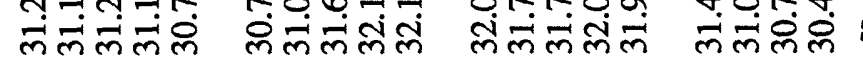

\section{눈연}

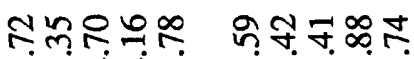

กี่

ิㅡำ

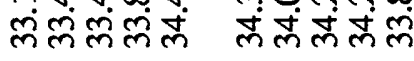

लंखिता

लंलंजिंले

लंत्रत्रत्ल

लिंक्लिंबं।

98

뜌규ํำ

ทำฺ

윤ㅈN

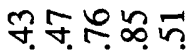

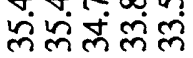

눙ำ

: 1 ! ñलn

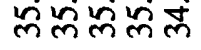

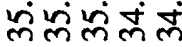

लेलm लें

लेंसें山ें लें

ㅊำำต

$\infty \infty$

ใูำชั

궁ㅇำำ

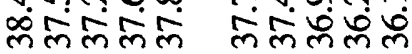

กำำำ.

ศิธิธุํํํํ

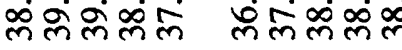

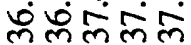

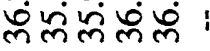

융ำ ケㅎㅀㅇ

๓

웅ㄴำ

உ్ํํํำ

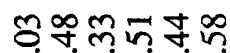

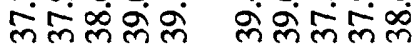

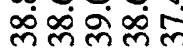

命成市

的的㡙

लंలి

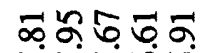

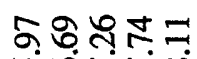

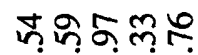

눙ำ

no

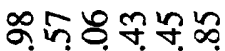

政需

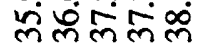

लें⿰丿⺄帀

舟㐫㐫宓

$\infty \circ$

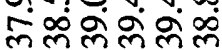

윤유

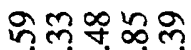

손ำํํำ

ชัญำก

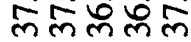

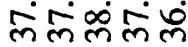

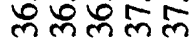

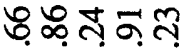

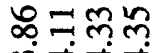

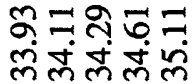

콩ํำ

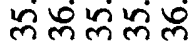

กิธีตสำ

| लेंसे

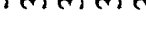

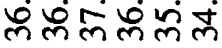

현구유 எㅇํㅇ

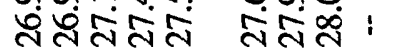

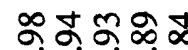

두요

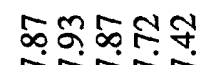

तกतत

ป तิลก

तัतกำ

누ㅇㅠㅛ 눈

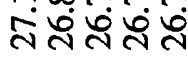

영뉴눈

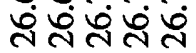

ఫా

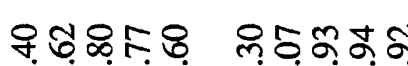

丈ㄴำำฺ

กูกำสฺุุ

낭ㅇㅇㅇ

त्रंष्तंत्त

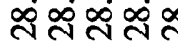

สำล

ลักิกลัก

ลัลลักล

ป กับ

ำกระป

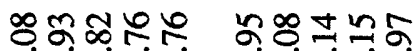

슊ํำ

눈유

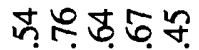

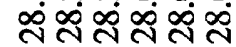

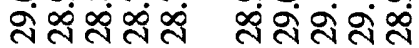

구요요

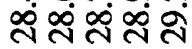

สิจंतี

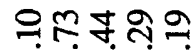

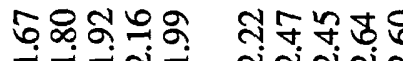

ㅇำำ

๓ุษดัษ

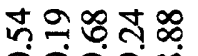

ํำ

กุก

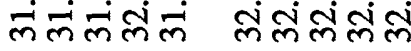

लिंलंळ्लि

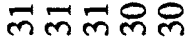

केष्लंतेंत्र

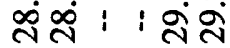

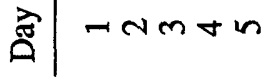

or $\infty$ a

ニッำ

으료음요

तกิูป็

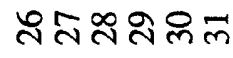




\begin{tabular}{|c|c|c|c|c|c|c|}
\hline$\stackrel{\mathscr{\Perp}}{\triangle}$ & $\begin{array}{lllll}1 & 1 & 1 & 1 & 1\end{array}$ & 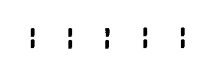 & $\begin{array}{lllll}1 & 1 & 1 & 1 & 1\end{array}$ & $\begin{array}{lllll}1 & 1 & 1 & 1 & 1\end{array}$ & 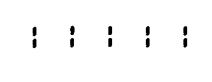 & $\begin{array}{llllll}1 & 1 & 1 & 1 & 1 & 1\end{array}$ \\
\hline z & $\begin{array}{lllll} & 1 & 1 & 1 & 1\end{array}$ & $1 \quad 1 \quad 1 \quad 1 \quad 1$ & $1 \quad 1 \quad 1 \quad 1 \quad 1$ & i $\quad \begin{array}{lll} & i & i\end{array}$ & $1 \quad 1 \quad 1 \quad 1 \quad 1$ & 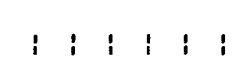 \\
\hline$\overline{8}$ & 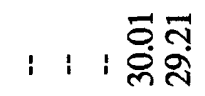 & 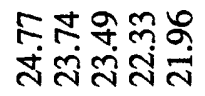 & 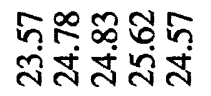 & 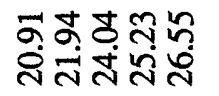 & 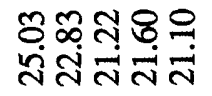 & 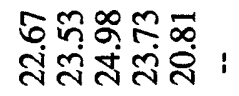 \\
\hline $\begin{array}{l}\overrightarrow{0} \\
\text { 心 } \\
\text { D. }\end{array}$ & 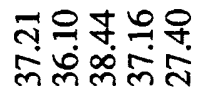 & 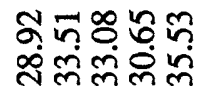 & 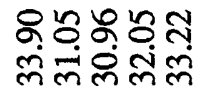 & 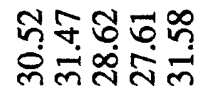 & 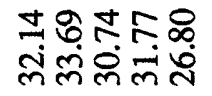 & 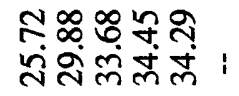 \\
\hline$\stackrel{\infty}{Z}$ & 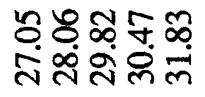 & 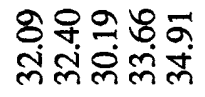 & 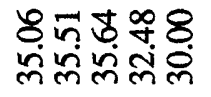 & 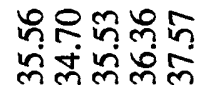 & 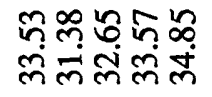 & 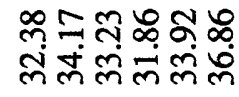 \\
\hline 窵 & 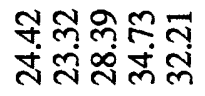 & 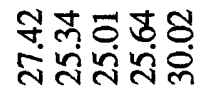 & 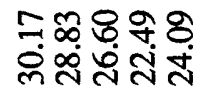 & 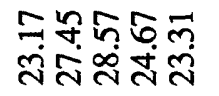 & 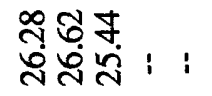 & 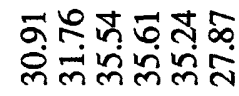 \\
\hline$\stackrel{\Xi}{\Xi}$ & 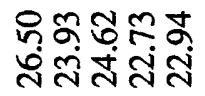 & 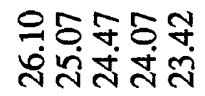 & 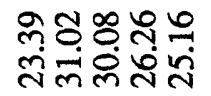 & 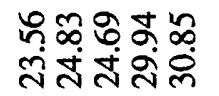 & 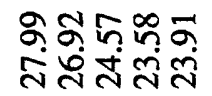 & 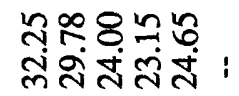 \\
\hline 丞 & 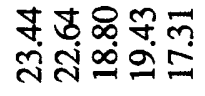 & 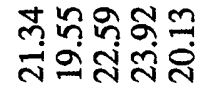 & 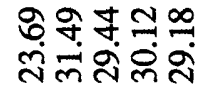 & 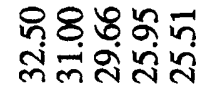 & 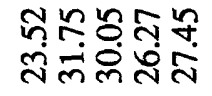 & 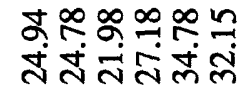 \\
\hline 妾 & 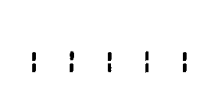 & 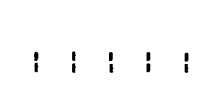 & $\begin{array}{lllll}1 & 1 & 1 & 1 & 1\end{array}$ & 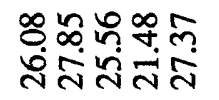 & 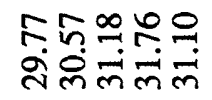 & 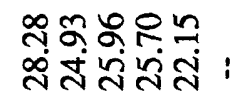 \\
\hline$\sum$ & 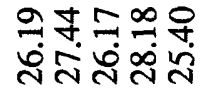 & 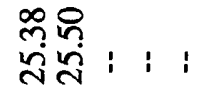 & $\begin{array}{lllll} & 1 & 1 & 1 & 1\end{array}$ & $1 \quad 1 \quad 1 \quad 1 \quad 1$ & 1 111 i 1 & 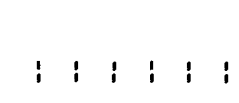 \\
\hline 这 & 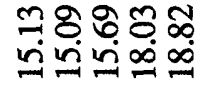 & 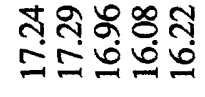 & 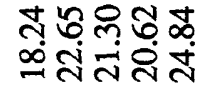 & 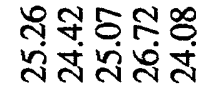 & 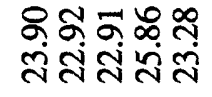 & 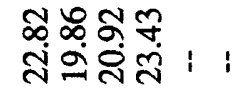 \\
\hline$\stackrel{\text { జ }}{\rightarrow}$ & 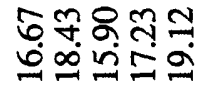 & 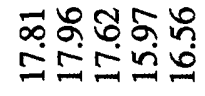 & 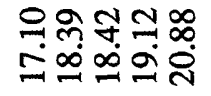 & 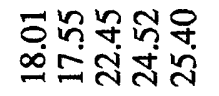 & 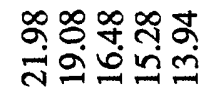 & 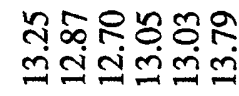 \\
\hline 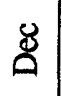 & 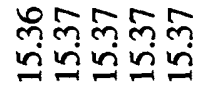 & 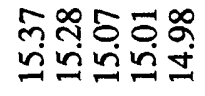 & 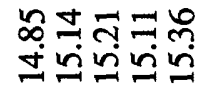 & 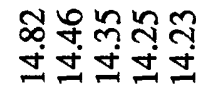 & 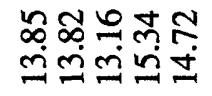 & 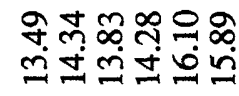 \\
\hline 完 & 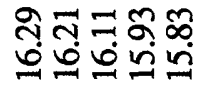 & 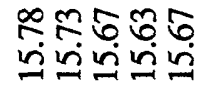 & 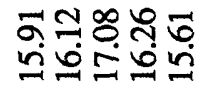 & 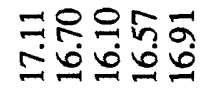 & 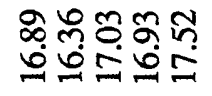 & 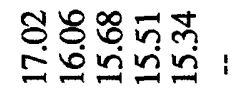 \\
\hline $\bar{\delta}$ & 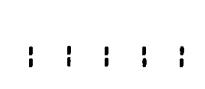 & i $\quad 1 \quad 1 \quad 1 \quad i$ & $\begin{array}{lllll}1 & 1 & 1 & 1 & 1\end{array}$ & 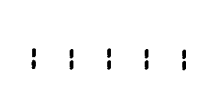 & $\begin{array}{lllll}1 & 1 & 1 & 1 & 1\end{array}$ & : : : : \\
\hline ज्ञ & $m+n$ & $-\infty$ a은 & $\exists N \cong \pm n$ & 어메요요 & 졿ำ & ్స유요 \\
\hline
\end{tabular}


Table 9. Chemical analyses of ground water in the Lompoc area

[Measured zone or aquifer was determined on the basis of well perforations and water quality. State well No.: See well$\mathrm{mg} / \mathrm{L}$, milligrams per liter; $\mu \mathrm{g} / \mathrm{L}$, micrograms per liter; <, actual value is less than value shown; --, no data. See figure 8 for

\begin{tabular}{|c|c|c|c|c|c|c|c|}
\hline $\begin{array}{l}\text { State well } \\
\text { No. }\end{array}$ & Date & $\begin{array}{c}\text { Specific } \\
\text { conductance } \\
(\mu \mathrm{S} / \mathrm{cm})\end{array}$ & $\begin{array}{c}\mathrm{pH} \\
\text { (standard } \\
\text { units) }\end{array}$ & $\begin{array}{c}\text { Temperature, } \\
\text { water } \\
\left({ }^{\circ} \mathrm{C}\right)\end{array}$ & $\begin{array}{c}\text { Calcium, } \\
\text { dissolved } \\
(\mathrm{mg} / \mathrm{L})\end{array}$ & $\begin{array}{c}\text { Magnesium, } \\
\text { dissolved } \\
(\mathrm{mg} / \mathrm{L})\end{array}$ & $\begin{array}{c}\text { Sodium, } \\
\text { dissolved } \\
(\mathrm{mg} / \mathrm{L})\end{array}$ \\
\hline \multicolumn{8}{|c|}{ Upper Aquifer--Shallow Zone } \\
\hline $7 \mathrm{~N} / 34 \mathrm{~W}-22 \mathrm{Q} 8$ & $12-21-88$ & 1,220 & 7.2 & 18.0 & 130 & 60 & 81 \\
\hline $27 \mathrm{~K} 4^{1}$ & $\begin{array}{r}5-07-87 \\
6-24-87 \\
9-11-87 \\
10-28-87 \\
1-07-88 \\
4-11-88 \\
7-21-88\end{array}$ & $\begin{array}{l}1,450 \\
1,400 \\
1,430 \\
1,570 \\
1,330 \\
1,330 \\
1,270\end{array}$ & \begin{tabular}{|l|l|}
7.6 & \\
7.7 \\
7.3 \\
7.8 \\
7.4 \\
7.3 \\
7.5
\end{tabular} & $\begin{array}{l}18.0 \\
17.0 \\
18.0 \\
18.5 \\
17.0 \\
17.5 \\
18.0\end{array}$ & $\begin{array}{l}140 \\
140 \\
140 \\
150 \\
130 \\
110 \\
120\end{array}$ & $\begin{array}{l}71 \\
64 \\
70 \\
70 \\
62 \\
51 \\
62\end{array}$ & $\begin{array}{l}82 \\
77 \\
82 \\
77 \\
67 \\
60 \\
72\end{array}$ \\
\hline $27 \mathrm{P}^{1}$ & $\begin{array}{l}3-18-87 \\
1-07-88 \\
4-14-88 \\
7-22-88\end{array}$ & $\begin{array}{l}1,300 \\
1,290 \\
1,330 \\
1,230\end{array}$ & $\begin{array}{l}7.8 \\
7.7 \\
7.4 \\
7.6\end{array}$ & $\begin{array}{l}17.5 \\
17.0 \\
16.0 \\
18.0\end{array}$ & $\begin{array}{l}140 \\
140 \\
140 \\
130\end{array}$ & $\begin{array}{l}70 \\
70 \\
73 \\
69\end{array}$ & $\begin{array}{l}56 \\
53 \\
60 \\
57\end{array}$ \\
\hline 28B5 & $12-20-88$ & 1,020 & 7.6 & 18.0 & 110 & 53 & 72 \\
\hline $28 \mathrm{~F} 1$ & $9-11-41$ & 5,620 & -- & -- & - & -- & -- \\
\hline $29 \mathrm{~F} 2^{1}$ & $\begin{array}{r}10-30-87 \\
1-06-88 \\
4-13-88 \\
7-22-88\end{array}$ & $\begin{array}{l}2,060 \\
2,150 \\
2,210 \\
2,110\end{array}$ & $\begin{array}{l}8.0 \\
7.4 \\
7.3 \\
7.5\end{array}$ & $\begin{array}{l}17.5 \\
16.5 \\
17.0 \\
18.0\end{array}$ & $\begin{array}{l}160 \\
170 \\
180 \\
150\end{array}$ & $\begin{array}{l}55 \\
59 \\
64 \\
57\end{array}$ & $\begin{array}{l}230 \\
240 \\
270 \\
250\end{array}$ \\
\hline $29 \mathrm{~N} 3^{1}$ & $\begin{array}{r}3-13-87 \\
5-05-87 \\
6-23-87 \\
9-11-87 \\
10-28-87 \\
1-05-88 \\
4-12-88 \\
7-23-88\end{array}$ & $\begin{array}{l}4,500 \\
4,350 \\
3,340 \\
4,110 \\
4,150 \\
4,030 \\
3,880 \\
4,540\end{array}$ & $\begin{array}{l}7.5 \\
7.6 \\
7.7 \\
7.2 \\
7.5 \\
7.6 \\
7.4 \\
7.3\end{array}$ & $\begin{array}{c}-- \\
-- \\
16.5 \\
17.0 \\
17.5 \\
- \\
\overline{16.0} \\
17.0\end{array}$ & $\begin{array}{l}440 \\
410 \\
390 \\
290 \\
320 \\
320 \\
340 \\
420\end{array}$ & $\begin{array}{l}300 \\
300 \\
320 \\
280 \\
300 \\
290 \\
330 \\
330\end{array}$ & $\begin{array}{r}250 \\
250 \\
170 \\
240 \\
58 \\
240 \\
230 \\
240\end{array}$ \\
\hline $29 \mathrm{~N} 4^{1}$ & $\begin{array}{r}3-13-87 \\
5-05-87 \\
6-23-87 \\
9-10-87 \\
10-28-87 \\
1-05-88 \\
4-12-88 \\
7-23-88\end{array}$ & $\begin{array}{l}3,510 \\
3,570 \\
3,210 \\
4,030 \\
4,100 \\
4,000 \\
4,100 \\
3,640\end{array}$ & $\begin{array}{l}7.5 \\
7.6 \\
8.0 \\
7.3 \\
7.5 \\
7.4 \\
7.4 \\
7.5\end{array}$ & \begin{tabular}{l|}
- \\
18.0 \\
16.5 \\
16.5 \\
17.5 \\
16.0 \\
16.0 \\
17.5
\end{tabular} & $\begin{array}{l}320 \\
340 \\
310 \\
330 \\
300 \\
290 \\
270 \\
330\end{array}$ & $\begin{array}{l}220 \\
230 \\
270 \\
320 \\
320 \\
270 \\
290 \\
370\end{array}$ & $\begin{array}{l}210 \\
200 \\
200 \\
230 \\
230 \\
220 \\
200 \\
220\end{array}$ \\
\hline $31 \mathrm{C} 3$ & $6-08-48$ & 1,700 & 7.9 & -- & 130 & 110 & 95 \\
\hline $31 \mathrm{R} 2$ & $6-26-87$ & 2,300 & -- & -- & -- & -- & - \\
\hline $32 \mathrm{~N} 1$ & $7-06-89$ & 2,510 & -- & -- & -. & -- & -- \\
\hline $33 E 5^{1}$ & $\begin{array}{l}1-07-88 \\
4-14-88 \\
7-24-88\end{array}$ & $\begin{array}{l}4,150 \\
4,210 \\
4,240\end{array}$ & $\begin{array}{l}7.3 \\
7.0 \\
7.2\end{array}$ & $\begin{array}{c}17.5 \\
16.0 \\
--\end{array}$ & $\begin{array}{l}370 \\
410 \\
470\end{array}$ & $\begin{array}{l}210 \\
230 \\
270\end{array}$ & $\begin{array}{l}240 \\
250 \\
240\end{array}$ \\
\hline
\end{tabular}

Footnotes at end of table. 
numbering sytem in text. Alkalinity: $\mathrm{L}$, laboratory value. $\mu \mathrm{S} / \mathrm{cm}$, microsiemens per centimeter at $25^{\circ} \mathrm{C}$; ${ }^{\circ} \mathrm{C}$, degree Celsius; location of wells]

\begin{tabular}{cccccccc}
\hline $\begin{array}{c}\text { Potassium, } \\
\text { dissolved } \\
(\mathrm{mg} / \mathrm{L})\end{array}$ & $\left.\begin{array}{c}\text { Alkalinity, } \\
\text { total, field } \\
(\mathrm{mg} / \mathrm{L} \text { as } \\
\mathrm{CaCO}\end{array}\right)$ & $\begin{array}{c}\text { Sulfate, } \\
\text { dissolved } \\
(\mathrm{mg} / \mathrm{L})\end{array}$ & $\begin{array}{c}\text { Chloride, } \\
\text { dissolved } \\
(\mathrm{mg} / \mathrm{L})\end{array}$ & $\begin{array}{c}\text { Solids, sum of } \\
\text { constituents, } \\
\text { dissolved } \\
(\mathrm{mg} / \mathrm{L})\end{array}$ & $\begin{array}{c}\text { Nitrogen, } \\
\text { nitrite plus nitrate, } \\
\text { dissolved } \\
(\mathrm{mg} / \mathrm{L} \text { as } \mathrm{N})\end{array}$ & $\begin{array}{c}\text { Boron, } \\
\text { dissolved } \\
(\mu \mathrm{g} / \mathrm{L})\end{array}$ & $\begin{array}{c}\text { Manganese, } \\
\text { dissolved } \\
(\mu \mathrm{g} / \mathrm{L})\end{array}$ \\
\hline
\end{tabular}

\begin{tabular}{|c|c|c|c|c|c|c|c|}
\hline \multicolumn{8}{|c|}{ Upper Aquifer--Shallow Zone--Continued } \\
\hline 3.9 & 407 & 280 & 61 & 892 & 1.1 & 420 & 1,000 \\
\hline 2.4 & 341 & 380 & 83 & 1,000 & 1.7 & 420 & 830 \\
\hline 2.6 & 326 & 360 & 76 & 956 & 1.7 & 400 & 780 \\
\hline 2.6 & 355 & 350 & 79 & 985 & 3.2 & 410 & 830 \\
\hline 3.7 & 341 & 400 & 80 & 1,030 & 2.8 & 430 & 900 \\
\hline 3.7 & 342 & 320 & 72 & 896 & .67 & 420 & 710 \\
\hline 1.7 & 302 & 340 & 67 & 839 & .16 & 410 & 620 \\
\hline 2.3 & 330 & 340 & 68 & 898 & .69 & 400 & 700 \\
\hline 3.6 & 375 & 280 & 59 & 872 & $<.10$ & 370 & 820 \\
\hline 3.6 & 441 & 260 & 55 & 885 & $<.10$ & 350 & 920 \\
\hline 2.7 & 424 & 280 & 60 & 909 & $<.10$ & 380 & 950 \\
\hline 2.8 & 398 & 250 & 51 & 836 & $<.10$ & 370 & 900 \\
\hline 3.3 & 263 & 300 & 52 & 779 & $<.10$ & 390 & 300 \\
\hline-- & -- & - & 840 & -- & -- & -- & -- \\
\hline 5.0 & 391 & 340 & 270 & 1,320 & $<.10$ & 630 & 480 \\
\hline 7.3 & 436 & 380 & 290 & 1,430 & $<.10$ & 610 & 560 \\
\hline 6.5 & 274 & 440 & 270 & 1,420 & .12 & 660 & 60 \\
\hline 6.9 & 394 & 430 & 240 & 1,400 & .36 & 600 & 640 \\
\hline 1.1 & 418 & 1,800 & 420 & 3,700 & 46 & 1,100 & 620 \\
\hline 2.6 & 427 & 1,900 & 410 & 3,680 & 30 & 1,100 & 940 \\
\hline 3.4 & 421 & 1,700 & 420 & 3,390 & 26 & 1,000 & 1,200 \\
\hline 3.6 & 431 & 1,600 & 360 & 3,100 & 11 & 1,100 & 1,400 \\
\hline 2.8 & 426 & 1,600 & 440 & 3,100 & 24 & 1,000 & 260 \\
\hline 3.6 & 440 & 1,800 & 280 & 3,220 & .16 & 1,000 & 1,000 \\
\hline 2.7 & 420 & 1,800 & 370 & 3,440 & 22 & 1,100 & 920 \\
\hline 2.7 & 442 & 1,900 & 420 & 3,790 & 42 & 990 & 330 \\
\hline 5.3 & 290 & 1,500 & 320 & 2,780 & $<.10$ & 780 & 2,100 \\
\hline 5.6 & 323 & 1,600 & 340 & 2,940 & .31 & 830 & 2,200 \\
\hline 4.4 & 369 & 1,500 & 320 & 2,860 & $<.10$ & 900 & 1,100 \\
\hline 4.5 & 407 & 1,700 & 350 & 3,200 & .30 & 940 & 1,400 \\
\hline 3.0 & 404 & 1,800 & 460 & 3,390 & $<.10$ & 920 & 1,200 \\
\hline 5.0 & 396 & 1,800 & 440 & 3,300 & $<.10$ & 860 & 1,400 \\
\hline 3.4 & 446 & 1,900 & 360 & 3,320 & $<.10$ & 960 & 910 \\
\hline 4.1 & 436 & 1,900 & 410 & 3,530 & $<.10$ & 910 & 970 \\
\hline 6.4 & 364 & 430 & 130 & 1,140 & -- & 500 & - \\
\hline-- & - & -- & - & 21,909 & -- & -- & -- \\
\hline -- & -- & -- & - & ${ }^{2} 2,083$ & - & -- & -- \\
\hline 7.3 & 813 & 1,400 & 450 & 3,200 & $<.10$ & 910 & 4,300 \\
\hline 5.4 & 704 & 1,500 & 380 & 3,250 & $<.10$ & 960 & 4,800 \\
\hline 6.1 & 768 & 1,500 & 390 & 3,380 & .68 & 920 & 4,500 \\
\hline
\end{tabular}


Table 9. Chemical analyses of ground water in the Lompoc area-Continued

\begin{tabular}{|c|c|c|c|c|c|c|c|}
\hline $\begin{array}{c}\text { State well } \\
\text { No. }\end{array}$ & Date & $\begin{array}{c}\text { Specific } \\
\text { conductance } \\
(\mu \mathrm{S} / \mathrm{cm})\end{array}$ & $\begin{array}{l}\mathrm{pH} \\
\text { (standard } \\
\text { units) }\end{array}$ & $\begin{array}{c}\text { Temperature, } \\
\text { water } \\
\left({ }^{\circ} \mathrm{C}\right)\end{array}$ & $\begin{array}{l}\text { Calcium, } \\
\text { dissolved } \\
(\mathrm{mg} / \mathrm{L})\end{array}$ & $\begin{array}{l}\text { Magnesium, } \\
\text { dissolved } \\
(\mathrm{mg} / \mathrm{L})\end{array}$ & $\begin{array}{c}\text { Sodium, } \\
\text { dissolved } \\
(\mathrm{mg} / \mathrm{L})\end{array}$ \\
\hline \multicolumn{8}{|c|}{ Upper Aquifer--Shallow Zone--Continued } \\
\hline $7 \mathrm{~N} / 34 \mathrm{~W}-35 \mathrm{~K} 14$ & $5-14-87$ & 2,880 & 7.3 & 21.0 & 260 & 130 & 230 \\
\hline $7 \mathrm{~N} / 35 \mathrm{~W}-13 \mathrm{~N} 2$ & $9-03-85$ & 674 & 6.4 & 20.0 & 17 & 12 & 120 \\
\hline $16 \mathrm{R} 1$ & $1-08-88$ & -- & 7.3 & 16.5 & 170 & 67 & 350 \\
\hline $17 \mathrm{G} 1$ & $\begin{array}{l}5-20-87 \\
9-28-88\end{array}$ & $\begin{array}{l}3,800 \\
4,210\end{array}$ & $\begin{array}{l}7.6 \\
7.5\end{array}$ & $\begin{array}{l}21.0 \\
22.0\end{array}$ & $\begin{array}{l}160 \\
140\end{array}$ & $\begin{array}{l}140 \\
160\end{array}$ & $\begin{array}{l}850 \\
910\end{array}$ \\
\hline $17 \mathrm{Q} 6$ & $\begin{array}{l}5-20-87 \\
6-23-88\end{array}$ & $\begin{array}{r}9,350 \\
10,700\end{array}$ & $\begin{array}{l}7.1 \\
7.1\end{array}$ & $\begin{array}{l}19.5 \\
19.5\end{array}$ & $\begin{array}{l}230 \\
290\end{array}$ & $\begin{array}{l}280 \\
350\end{array}$ & $\begin{array}{l}2,200 \\
2,200\end{array}$ \\
\hline $23 \mathrm{~B} 2^{1}$ & $\begin{array}{l}5-08-87 \\
4-15-88 \\
6-24-88\end{array}$ & $\begin{array}{r}1,410 \\
1,280\end{array}$ & $\begin{array}{l}7.9 \\
7.7 \\
7.7\end{array}$ & $\begin{array}{l}17.0 \\
\overline{16.0}\end{array}$ & $\begin{array}{l}64 \\
69 \\
70\end{array}$ & $\begin{array}{l}29 \\
32 \\
32\end{array}$ & $\begin{array}{l}180 \\
180 \\
180\end{array}$ \\
\hline $23 \mathrm{~J} 3$ & $6-04-48$ & 4,530 & -- & 17.0 & 420 & 200 & 420 \\
\hline $23 \mathrm{Q} 1^{1}$ & $\begin{array}{r}3-17-87 \\
5-07-87 \\
6-24-87 \\
9-09-87 \\
10-28-87 \\
1-05-88 \\
4-13-88 \\
7-24-88\end{array}$ & $\begin{array}{r}7,000 \\
7,270 \\
-- \\
6,770 \\
6,870 \\
6,940 \\
6,910 \\
6,440\end{array}$ & $\begin{array}{l}7.7 \\
7.5 \\
8.2 \\
7.1 \\
7.6 \\
7.5 \\
7.4 \\
7.5\end{array}$ & $\begin{array}{l}17.0 \\
18.5 \\
17.5 \\
17.5 \\
17.5 \\
17.5 \\
18.0 \\
17.5\end{array}$ & $\begin{array}{l}360 \\
360 \\
370 \\
340 \\
320 \\
320 \\
320 \\
350\end{array}$ & $\begin{array}{l}300 \\
310 \\
340 \\
310 \\
320 \\
290 \\
310 \\
320\end{array}$ & $\begin{array}{r}990 \\
970 \\
1,000 \\
1,000 \\
990 \\
890 \\
950 \\
1,000\end{array}$ \\
\hline $23 \mathrm{Q} 2^{1}$ & $\begin{array}{r}3-17-87 \\
5-07-87 \\
6-24-87 \\
9-09-87 \\
10-28-87 \\
1-05-88 \\
4-13-88 \\
7-23-88\end{array}$ & $\begin{array}{l}6,280 \\
6,710 \\
5,380 \\
6,610 \\
6,680 \\
6,820 \\
6,600 \\
6,010\end{array}$ & $\begin{array}{l}7.8 \\
7.9 \\
7.7 \\
7.5 \\
7.8 \\
7.8 \\
7.6 \\
7.7\end{array}$ & $\begin{array}{l}17.0 \\
17.5 \\
17.5 \\
17.5 \\
18.0 \\
17.5 \\
17.0 \\
18.0\end{array}$ & $\begin{array}{l}320 \\
330 \\
330 \\
260 \\
300 \\
240 \\
290 \\
310\end{array}$ & $\begin{array}{l}280 \\
330 \\
360 \\
320 \\
370 \\
320 \\
350 \\
360\end{array}$ & $\begin{array}{l}850 \\
890 \\
870 \\
900 \\
870 \\
860 \\
850 \\
820\end{array}$ \\
\hline 23Q5LYS & $\begin{array}{r}6-24-87 \\
9-09-87 \\
10-28-87 \\
4-11-88 \\
7-24-88\end{array}$ & $\begin{array}{l}4,610 \\
4,680 \\
5,070 \\
5,850 \\
5,810\end{array}$ & $\begin{array}{l}7.9 \\
7.6 \\
7.8 \\
7.9 \\
7.8\end{array}$ & $\begin{array}{l}19.5 \\
18.5 \\
19.0 \\
15.0 \\
17.5\end{array}$ & $\begin{array}{l}530 \\
550 \\
550 \\
590 \\
600\end{array}$ & $\begin{array}{l}240 \\
250 \\
230 \\
340 \\
360\end{array}$ & $\begin{array}{l}380 \\
390 \\
370 \\
430 \\
450\end{array}$ \\
\hline $26 \mathrm{~L} 1^{1}$ & $\begin{array}{r}3-18-87 \\
5-06-87 \\
6-23-87 \\
9-11-87 \\
10-28-87 \\
1-05-88 \\
4-12-88 \\
7-23-88\end{array}$ & $\begin{array}{l}3,860 \\
4,160 \\
4,000 \\
4,140 \\
4,120 \\
4,410 \\
4,600 \\
5,700\end{array}$ & $\begin{array}{l}7.8 \\
7.7 \\
8.1 \\
7.2 \\
7.6 \\
7.5 \\
7.5 \\
7.5\end{array}$ & $\begin{array}{l}17.0 \\
18.0 \\
17.5 \\
18.0 \\
17.5 \\
-\ddot{18.0} \\
17.0\end{array}$ & $\begin{array}{l}140 \\
210 \\
210 \\
180 \\
200 \\
220 \\
220 \\
230\end{array}$ & $\begin{array}{l}230 \\
260 \\
280 \\
250 \\
270 \\
250 \\
270 \\
350\end{array}$ & $\begin{array}{l}450 \\
420 \\
390 \\
390 \\
380 \\
360 \\
410 \\
710\end{array}$ \\
\hline
\end{tabular}

Footnotes at end of table. 


\begin{tabular}{|c|c|c|c|c|c|c|c|}
\hline $\begin{array}{l}\text { Potassium, } \\
\text { dissolved } \\
(\mathrm{mg} / \mathrm{L})\end{array}$ & $\begin{array}{c}\text { Alkalinity, } \\
\text { total, field } \\
(\mathrm{mg} / \mathrm{L} \text { as } \\
\left.\mathrm{CaCO}_{3}\right)\end{array}$ & $\begin{array}{l}\text { Sulfate, } \\
\text { dissolved } \\
\text { (mg/L) }\end{array}$ & $\begin{array}{l}\text { Chloride, } \\
\text { dissolved } \\
\text { (mg/L) }\end{array}$ & $\begin{array}{l}\text { Solids, sum of } \\
\text { constituents, } \\
\text { dissolved } \\
(\mathrm{mg} / \mathrm{L})\end{array}$ & $\begin{array}{c}\text { Nitrogen, } \\
\text { nitrite plus nitrate, } \\
\text { dissolved } \\
(\mathrm{mg} / \mathrm{L} \text { as } \mathrm{N})\end{array}$ & $\begin{array}{c}\text { Boron, } \\
\text { dissolved } \\
(\mu \mathrm{g} / \mathrm{L})\end{array}$ & $\begin{array}{c}\text { Manganese, } \\
\text { dissolved } \\
(\mu \mathrm{g} / \mathrm{L})\end{array}$ \\
\hline \multicolumn{8}{|c|}{ Upper Aquifer--Shallow Zone--Continued } \\
\hline 13 & 548 & 100 & 290 & 1,430 & 7.3 & 930 & 490 \\
\hline 20 & 64 & 120 & 160 & 542 & -- & -- & -. \\
\hline 10 & L507 & 290 & 550 & 1,770 & $<.10$ & 570 & 1,300 \\
\hline $\begin{array}{l}23 \\
21\end{array}$ & $\begin{array}{l}600 \\
644\end{array}$ & $\begin{array}{l}270 \\
250\end{array}$ & $\begin{array}{l}1,400 \\
1,500\end{array}$ & $\begin{array}{l}3,240 \\
3,410\end{array}$ & $\begin{array}{l}<.10 \\
<.10\end{array}$ & $\begin{array}{l}1,700 \\
1,500\end{array}$ & $\begin{array}{l}580 \\
560\end{array}$ \\
\hline $\begin{array}{l}58 \\
44\end{array}$ & $\begin{array}{l}498 \\
507\end{array}$ & $\begin{array}{l}1,000 \\
1,100\end{array}$ & $\begin{array}{l}3,700 \\
3,900\end{array}$ & $\begin{array}{l}7,780 \\
8,240\end{array}$ & $\begin{array}{l}<.10 \\
<.10\end{array}$ & $\begin{array}{l}1,600 \\
1,600\end{array}$ & $\begin{array}{l}590 \\
610\end{array}$ \\
\hline $\begin{array}{l}2.1 \\
1.8 \\
1.9\end{array}$ & $\begin{array}{r}160 \\
\mathrm{~L} 144 \\
192\end{array}$ & $\begin{array}{l}230 \\
250 \\
240\end{array}$ & $\begin{array}{l}220 \\
230 \\
220\end{array}$ & $\begin{array}{l}849 \\
875 \\
889\end{array}$ & $\begin{array}{l}<.10 \\
<.10 \\
<.10\end{array}$ & $\begin{array}{l}270 \\
260 \\
270\end{array}$ & $\begin{array}{l}400 \\
440 \\
440\end{array}$ \\
\hline 18 & 460 & 1,400 & 640 & 3,410 & -- & 1,100 & -. \\
\hline $\begin{array}{r}16 \\
6.9 \\
5.6 \\
4.8 \\
1.4 \\
5.2 \\
4.4 \\
4.5\end{array}$ & $\begin{array}{l}363 \\
373 \\
326 \\
376 \\
367 \\
364 \\
402 \\
321\end{array}$ & $\begin{array}{l}2,900 \\
2,900 \\
2,800 \\
2,900 \\
2,900 \\
2,800 \\
3,000 \\
3,000\end{array}$ & $\begin{array}{l}740 \\
700 \\
630 \\
650 \\
680 \\
640 \\
630 \\
660\end{array}$ & $\begin{array}{l}5,910 \\
5,790 \\
5,670 \\
5,810 \\
5,760 \\
5,200 \\
5,730 \\
5,860\end{array}$ & $\begin{array}{l}81 \\
65 \\
66 \\
78 \\
66 \\
.76 \\
57 \\
67\end{array}$ & $\begin{array}{l}3,400 \\
3,300 \\
3,200 \\
3,200 \\
3,400 \\
3,100 \\
3,100 \\
3,000\end{array}$ & $\begin{array}{r}1,700 \\
2,100 \\
2,500 \\
2,500 \\
2,100 \\
1,900 \\
540 \\
1,400\end{array}$ \\
\hline $\begin{array}{c}11 \\
6.3 \\
6.0 \\
6.3 \\
3.9 \\
6.5 \\
5.7 \\
6.0\end{array}$ & $\begin{array}{l}316 \\
347 \\
367 \\
381 \\
364 \\
376 \\
354 \\
394\end{array}$ & $\begin{array}{l}2,600 \\
2,700 \\
2,600 \\
2,700 \\
2,700 \\
2,800 \\
2,800 \\
2,700\end{array}$ & $\begin{array}{l}760 \\
730 \\
750 \\
730 \\
730 \\
630 \\
580 \\
680\end{array}$ & $\begin{array}{l}5,130 \\
5,260 \\
5,450 \\
5,500 \\
5,500 \\
5,330 \\
5,380 \\
5,440\end{array}$ & $\begin{array}{c}21 \\
9.3 \\
65 \\
74 \\
63 \\
50 \\
61 \\
67\end{array}$ & $\begin{array}{l}2,700 \\
3,000 \\
3,100 \\
3,200 \\
3,100 \\
2,900 \\
2,800 \\
2,800\end{array}$ & $\begin{array}{l}680 \\
560 \\
500 \\
500 \\
440 \\
470 \\
340 \\
350\end{array}$ \\
\hline $\begin{array}{l}9.6 \\
4.3 \\
1.6 \\
2.6 \\
2.9\end{array}$ & $\begin{array}{r}\text { L380 } \\
374 \\
363 \\
358 \\
359\end{array}$ & $\begin{array}{l}1,800 \\
1,900 \\
2,100 \\
2,600 \\
2,400\end{array}$ & $\begin{array}{l}660 \\
580 \\
590 \\
680 \\
570\end{array}$ & $\begin{array}{l}4,460 \\
4,380 \\
4,520 \\
5,470 \\
5,120\end{array}$ & $\begin{array}{r}130 \\
100 \\
96 \\
130 \\
110\end{array}$ & $\begin{array}{l}1,600 \\
1,800 \\
1,700 \\
2,000 \\
2,000\end{array}$ & $\begin{array}{l}80 \\
40 \\
10 \\
20 \\
30\end{array}$ \\
\hline $\begin{array}{l}3.4 \\
2.2 \\
1.8 \\
1.4 \\
5.3 \\
1.8 \\
1.3 \\
1.4\end{array}$ & $\begin{array}{r}458 \\
381 \\
403 \\
383 \\
404 \\
\mathrm{~L} 390 \\
444 \\
520\end{array}$ & $\begin{array}{l}1,300 \\
1,400 \\
1,400 \\
1,400 \\
1,400 \\
1,500 \\
1,600 \\
2,300\end{array}$ & $\begin{array}{l}380 \\
440 \\
420 \\
410 \\
440 \\
460 \\
330 \\
450\end{array}$ & $\begin{array}{l}2,880 \\
3,230 \\
3,210 \\
3,150 \\
2,990 \\
3,060 \\
3,390 \\
4,630\end{array}$ & $\begin{array}{l}17 \\
53 \\
53 \\
57 \\
.22 \\
.61 \\
58 \\
54\end{array}$ & $\begin{array}{l}1,400 \\
1,300 \\
1,100 \\
1,200 \\
1,200 \\
1,100 \\
1,300 \\
1,700\end{array}$ & $\begin{array}{l}1,000 \\
1,800 \\
2,000 \\
2,100 \\
1,800 \\
1,900 \\
1,900 \\
2,200\end{array}$ \\
\hline
\end{tabular}


Table 9. Chemical analyses of ground water in the Lompoc area--Continued

\begin{tabular}{|c|c|c|c|c|c|c|c|}
\hline $\begin{array}{l}\text { State well } \\
\text { No. }\end{array}$ & Date & $\begin{array}{c}\text { Specific } \\
\text { conductance } \\
(\mu \mathrm{S} / \mathrm{cm})\end{array}$ & $\begin{array}{c}\mathrm{pH} \\
\text { (standard } \\
\text { units) }\end{array}$ & $\begin{array}{c}\text { Temperature, } \\
\text { water } \\
\left({ }^{\circ} \mathrm{C}\right)\end{array}$ & $\begin{array}{c}\text { Calcium, } \\
\text { dissolved } \\
(\mathrm{mg} / \mathrm{L})\end{array}$ & $\begin{array}{c}\text { Magnesium, } \\
\text { dissolved } \\
(\mathrm{mg} / \mathrm{L})\end{array}$ & $\begin{array}{c}\text { Sodium, } \\
\text { dissolved } \\
(\mathrm{mg} / \mathrm{L})\end{array}$ \\
\hline \multicolumn{8}{|c|}{ Upper Aquifer--Shallow Zone--Continued } \\
\hline $7 \mathrm{~N} / 35 \mathrm{~W}-26 \mathrm{~L} 3 \mathrm{LYS}$ & $\begin{array}{r}5-06-87 \\
6-23-87 \\
9-11-87 \\
10-28-87 \\
4-11-88 \\
7-23-88\end{array}$ & $\begin{array}{l}4,220 \\
3,320 \\
4,120 \\
4,060 \\
4,020 \\
4,080\end{array}$ & $\begin{array}{l}7.7 \\
8.1 \\
8.1 \\
8.0 \\
8.0 \\
7.8\end{array}$ & $\begin{array}{l}- \\
17.5 \\
18.0 \\
18.5 \\
15.0 \\
19.0\end{array}$ & $\begin{array}{l}320 \\
300 \\
330 \\
300 \\
280 \\
300\end{array}$ & $\begin{array}{l}270 \\
260 \\
310 \\
280 \\
230 \\
280\end{array}$ & $\begin{array}{l}320 \\
270 \\
310 \\
300 \\
300 \\
270\end{array}$ \\
\hline \multicolumn{8}{|c|}{ Upper Aquifer--Middle Zone } \\
\hline $7 \mathrm{~N} / 34 \mathrm{~W}-26 \mathrm{R} 2$ & $\begin{array}{l}5-13-87 \\
4-15-88\end{array}$ & $\begin{array}{l}2,860 \\
2,480\end{array}$ & $\begin{array}{l}7.5 \\
--\end{array}$ & $\begin{array}{l}19.0 \\
18.5\end{array}$ & $\begin{array}{r}240 \\
--\end{array}$ & $\begin{array}{r}120 \\
--\end{array}$ & $\begin{array}{r}210 \\
--\end{array}$ \\
\hline $27 \mathrm{E} 4^{1}$ & $\begin{array}{l}1-07-88 \\
4-14-88 \\
7-22-88\end{array}$ & $\begin{array}{l}2,890 \\
2,830 \\
2,910\end{array}$ & $\begin{array}{l}7.5 \\
7.3 \\
7.4\end{array}$ & $\begin{array}{c}18.0 \\
17.0 \\
--\end{array}$ & $\begin{array}{l}250 \\
240 \\
270\end{array}$ & $\begin{array}{l}140 \\
150 \\
160\end{array}$ & $\begin{array}{l}230 \\
230 \\
220\end{array}$ \\
\hline $27 \mathrm{~K} 5^{1}$ & $\begin{array}{r}3-18-87 \\
5-07-87 \\
6-24-87 \\
9-11-87 \\
10-28-87 \\
1-07-88 \\
4-11-88 \\
7-21-88\end{array}$ & $\begin{array}{l}1,340 \\
1,460 \\
1,380 \\
1,090 \\
1,520 \\
1,470 \\
1,360 \\
1,390\end{array}$ & $\begin{array}{l}7.8 \\
7.7 \\
8.2 \\
7.5 \\
7.6 \\
7.7 \\
7.5 \\
7.9\end{array}$ & $\begin{array}{l}17.0 \\
18.0 \\
17.0 \\
18.5 \\
18.0 \\
17.0 \\
17.0 \\
18.0\end{array}$ & $\begin{array}{l}140 \\
130 \\
140 \\
140 \\
150 \\
150 \\
150 \\
120\end{array}$ & $\begin{array}{l}70 \\
72 \\
71 \\
73 \\
74 \\
76 \\
73 \\
72\end{array}$ & $\begin{array}{l}74 \\
72 \\
73 \\
73 \\
75 \\
73 \\
77 \\
75\end{array}$ \\
\hline $27 N 6$ & $10-30-87$ & 2,100 & 7.5 & 18.0 & 180 & 97 & 120 \\
\hline $28 \mathrm{M}^{1}$ & $\begin{array}{r}10-30-87 \\
1-06-88 \\
4-14-88 \\
7-22-88\end{array}$ & $\begin{array}{l}3,790 \\
3,590 \\
3,560 \\
3,690\end{array}$ & $\begin{array}{l}7.5 \\
7.7 \\
7.6 \\
7.8\end{array}$ & $\begin{array}{l}18.0 \\
16.5 \\
17.0 \\
17.5\end{array}$ & $\begin{array}{l}180 \\
190 \\
210 \\
260\end{array}$ & $\begin{array}{l}140 \\
160 \\
180 \\
210\end{array}$ & $\begin{array}{l}460 \\
390 \\
410 \\
400\end{array}$ \\
\hline $28 \mathrm{Q} 1$ & $\begin{array}{l}1-07-88 \\
7-26-88\end{array}$ & $\begin{array}{l}2,260 \\
1,950\end{array}$ & $\begin{array}{l}7.4 \\
7.6\end{array}$ & $\begin{array}{l}17.5 \\
18.0\end{array}$ & $\begin{array}{l}180 \\
160\end{array}$ & $\begin{array}{l}110 \\
100\end{array}$ & $\begin{array}{l}110 \\
130\end{array}$ \\
\hline $29 \mathrm{H} 3^{1}$ & $\begin{array}{r}10-30-87 \\
1-06-88 \\
4-14-88 \\
7-22-88\end{array}$ & $\begin{array}{l}2,370 \\
2,160 \\
1,920 \\
1,970\end{array}$ & $\begin{array}{l}7.5 \\
7.4 \\
7.3 \\
7.6\end{array}$ & $\begin{array}{l}18.0 \\
18.0 \\
17.0 \\
18.5\end{array}$ & $\begin{array}{l}180 \\
210 \\
170 \\
180\end{array}$ & $\begin{array}{r}99 \\
100 \\
94 \\
100\end{array}$ & $\begin{array}{l}190 \\
170 \\
150 \\
150\end{array}$ \\
\hline $29 \mathrm{L1}$ & $7-06-89$ & 2,350 & -- & -- & -- & - & -- \\
\hline $29 \mathrm{~N} 5^{1}$ & $\begin{array}{r}3-13-87 \\
5-05-87 \\
6-23-87 \\
9-10-87 \\
10-28-87 \\
1-05-88 \\
4-12-88 \\
7-23-88\end{array}$ & $\begin{array}{l}2,590 \\
2,290 \\
2,250 \\
2,360 \\
2,490 \\
2,520 \\
2,550 \\
2,220\end{array}$ & $\begin{array}{l}7.4 \\
7.4 \\
7.8 \\
7.1 \\
7.5 \\
7.5 \\
7.4 \\
7.5\end{array}$ & $\begin{array}{l}-- \\
18.0 \\
16.5 \\
16.5 \\
17.0 \\
-- \\
16.0 \\
18.5\end{array}$ & $\begin{array}{l}210 \\
200 \\
190 \\
180 \\
200 \\
200 \\
220 \\
250\end{array}$ & $\begin{array}{l}130 \\
110 \\
100 \\
120 \\
120 \\
120 \\
130 \\
150\end{array}$ & $\begin{array}{l}210 \\
190 \\
170 \\
170 \\
170 \\
140 \\
150 \\
140\end{array}$ \\
\hline
\end{tabular}

Footnotes at end of table. 


\begin{tabular}{|c|c|c|c|c|c|c|c|}
\hline $\begin{array}{l}\text { Potassium, } \\
\text { dissolved } \\
(\mathrm{mg} / \mathrm{L})\end{array}$ & $\begin{array}{c}\text { Alkalinity, } \\
\text { total, field } \\
(\mathrm{mg} / \mathrm{L} \text { as } \\
\left.\mathrm{CaCO}_{3}\right)\end{array}$ & $\begin{array}{c}\text { Sulfate, } \\
\text { dissolved } \\
(\mathrm{mg} / \mathrm{L})\end{array}$ & $\begin{array}{l}\text { Chloride, } \\
\text { dissolved } \\
(\mathrm{mg} / \mathrm{L})\end{array}$ & $\begin{array}{l}\text { Solids, sum of } \\
\text { constituents, } \\
\text { dissolved } \\
(\mathrm{mg} / \mathrm{L})\end{array}$ & $\begin{array}{l}\text { Nitrogen, } \\
\text { nitrite plus nitrate, } \\
\text { dissolved } \\
(\mathrm{mg} / \mathrm{L} \text { as } \mathrm{N})\end{array}$ & $\begin{array}{l}\text { Boron, } \\
\text { dissolved } \\
(\mu \mathrm{g} / \mathrm{L})\end{array}$ & $\begin{array}{l}\text { Manganese, } \\
\text { dissolved } \\
(\mu \mathrm{g} / \mathrm{L})\end{array}$ \\
\hline \multicolumn{8}{|c|}{ Upper Aquifer--Shallow Zone--Continued } \\
\hline $\begin{array}{l}6.4 \\
2.9 \\
1.8 \\
2.4 \\
1.2 \\
1.2\end{array}$ & $\begin{array}{r}\text { L332 } \\
180 \\
348 \\
344 \\
376 \\
370\end{array}$ & $\begin{array}{l}1,500 \\
1,600 \\
1,600 \\
1,700 \\
1,300 \\
1,400\end{array}$ & $\begin{array}{l}490 \\
480 \\
440 \\
480 \\
310 \\
380\end{array}$ & $\begin{array}{l}3,390 \\
3,270 \\
3,440 \\
3,480 \\
2,950 \\
3,120\end{array}$ & $\begin{array}{l}58 \\
50 \\
48 \\
42 \\
62 \\
54\end{array}$ & $\begin{array}{r}970 \\
1,100 \\
1,200 \\
1,200 \\
850 \\
910\end{array}$ & $\begin{array}{r}80 \\
170 \\
120 \\
20 \\
20 \\
40\end{array}$ \\
\hline \multicolumn{8}{|c|}{ Upper Aquifer--Middle Zone--Continued } \\
\hline $\begin{array}{l}6.4 \\
--\end{array}$ & $\begin{array}{r}448 \\
--\end{array}$ & $\begin{array}{r}640 \\
--\end{array}$ & $\begin{array}{r}360 \\
--\end{array}$ & $\begin{array}{r}1,990 \\
--\end{array}$ & $\begin{array}{c}24 \\
--\end{array}$ & $\begin{array}{r}850 \\
--\end{array}$ & $\begin{array}{c}60 \\
--\end{array}$ \\
\hline $\begin{array}{l}6.4 \\
4.5 \\
4.0\end{array}$ & $\begin{array}{l}591 \\
536 \\
598\end{array}$ & $\begin{array}{l}1,100 \\
1,100 \\
1,100\end{array}$ & $\begin{array}{l}140 \\
170 \\
170\end{array}$ & $\begin{array}{l}2,250 \\
2,250 \\
2,320\end{array}$ & $\begin{array}{r}<.10 \\
<.10 \\
.13\end{array}$ & $\begin{array}{l}1,200 \\
1,200 \\
1,200\end{array}$ & $\begin{array}{l}2,600 \\
2,700 \\
2,900\end{array}$ \\
\hline $\begin{array}{l}3.3 \\
2.8 \\
2.8 \\
2.9 \\
8.5 \\
3.5 \\
2.7 \\
2.7\end{array}$ & $\begin{array}{l}299 \\
301 \\
323 \\
336 \\
320 \\
318 \\
396 \\
344\end{array}$ & $\begin{array}{l}370 \\
360 \\
390 \\
380 \\
390 \\
380 \\
350 \\
380\end{array}$ & $\begin{array}{l}79 \\
89 \\
84 \\
88 \\
86 \\
80 \\
75 \\
82\end{array}$ & $\begin{array}{r}954 \\
945 \\
993 \\
996 \\
1,010 \\
991 \\
1,000 \\
973\end{array}$ & $\begin{array}{l}<.10 \\
<.10 \\
<.10 \\
<.10 \\
<.10 \\
<.10 \\
<.10 \\
<.10\end{array}$ & $\begin{array}{l}430 \\
400 \\
430 \\
420 \\
430 \\
400 \\
380 \\
400\end{array}$ & $\begin{array}{l}620 \\
630 \\
620 \\
600 \\
630 \\
610 \\
620 \\
530\end{array}$ \\
\hline 1.2 & 340 & 680 & 150 & 1,460 & $<.10$ & 600 & 590 \\
\hline $\begin{array}{l}4.4 \\
3.0 \\
2.4 \\
2.6\end{array}$ & $\begin{array}{l}233 \\
285 \\
280 \\
304\end{array}$ & $\begin{array}{l}1,500 \\
1,700 \\
1,600 \\
1,700\end{array}$ & $\begin{array}{l}220 \\
200 \\
240 \\
250\end{array}$ & $\begin{array}{l}2,700 \\
2,880 \\
2,910 \\
3,110\end{array}$ & $\begin{array}{l}6.5 \\
8.2 \\
16 \\
18\end{array}$ & $\begin{array}{l}1,700 \\
1,700 \\
1,700 \\
1,600\end{array}$ & $\begin{array}{r}1,400 \\
1,500 \\
980 \\
960\end{array}$ \\
\hline $\begin{array}{l}3.5 \\
2.5\end{array}$ & $\begin{array}{l}506 \\
509\end{array}$ & $\begin{array}{l}630 \\
450\end{array}$ & $\begin{array}{l}220 \\
150\end{array}$ & $\begin{array}{l}1,600 \\
1,340\end{array}$ & $\begin{array}{r}<.10 \\
.39\end{array}$ & $\begin{array}{l}560 \\
550\end{array}$ & $\begin{array}{r}1,500 \\
980\end{array}$ \\
\hline $\begin{array}{l}8.4 \\
8.6 \\
6.1 \\
7.0\end{array}$ & $\begin{array}{l}422 \\
531 \\
480 \\
490\end{array}$ & $\begin{array}{l}670 \\
590 \\
490 \\
500\end{array}$ & $\begin{array}{l}150 \\
140 \\
130 \\
120\end{array}$ & $\begin{array}{l}1,580 \\
1,570 \\
1,360 \\
1,390\end{array}$ & $\begin{array}{l}<.10 \\
<.10 \\
<.10 \\
<.10\end{array}$ & $\begin{array}{l}560 \\
610 \\
480 \\
460\end{array}$ & $\begin{array}{r}1,200 \\
1,100 \\
890 \\
1,000\end{array}$ \\
\hline- & -- & -- & -- & ${ }^{2} 1,739$ & -- & -- & -- \\
\hline $\begin{array}{l}4.2 \\
4.6 \\
4.7 \\
5.0 \\
4.4 \\
4.7 \\
4.1 \\
4.9\end{array}$ & $\begin{array}{l}438 \\
445 \\
438 \\
460 \\
462 \\
446 \\
452 \\
476\end{array}$ & $\begin{array}{l}840 \\
640 \\
640 \\
660 \\
760 \\
710 \\
810 \\
810\end{array}$ & $\begin{array}{l}200 \\
190 \\
190 \\
200 \\
210 \\
230 \\
210 \\
210\end{array}$ & $\begin{array}{l}1,860 \\
1,640 \\
1,590 \\
1,650 \\
1,780 \\
1,710 \\
1,830 \\
1,890\end{array}$ & $\begin{array}{r}.76 \\
.55 \\
<.10 \\
.42 \\
.18 \\
<.10 \\
<.10 \\
.25\end{array}$ & $\begin{array}{l}560 \\
550 \\
530 \\
520 \\
530 \\
470 \\
490 \\
460\end{array}$ & $\begin{array}{l}1,500 \\
1,200 \\
1,300 \\
1,600 \\
1,600 \\
1,500 \\
1,800 \\
1,900\end{array}$ \\
\hline
\end{tabular}


Table 9. Chemical analyses of ground water in the Lompoc area-Continued

\begin{tabular}{|c|c|c|c|c|c|c|c|}
\hline $\begin{array}{l}\text { State well } \\
\text { No. }\end{array}$ & Date & $\begin{array}{c}\text { Specific } \\
\text { conductance } \\
(\mu \mathrm{S} / \mathrm{cm})\end{array}$ & $\begin{array}{c}\mathrm{pH} \\
\text { (standard } \\
\text { units) }\end{array}$ & $\begin{array}{c}\text { Temperature, } \\
\text { water } \\
\left({ }^{\circ} \mathrm{C}\right)\end{array}$ & $\begin{array}{l}\text { Calcium, } \\
\text { dissolved } \\
(\mathrm{mg} / \mathrm{L})\end{array}$ & $\begin{array}{l}\text { Magnesium, } \\
\text { dissolved } \\
(\mathrm{mg} / \mathrm{L})\end{array}$ & $\begin{array}{l}\text { Sodium, } \\
\text { dissolved } \\
(\mathrm{mg} / \mathrm{L})\end{array}$ \\
\hline \multicolumn{8}{|c|}{ Upper Aquifer--Middle Zone--Continued } \\
\hline $7 \mathrm{~N} / 35 \mathrm{~W}-23 \mathrm{Q} 3^{1}$ & $\begin{array}{r}5-07-87 \\
6-24-87 \\
9-09-87 \\
10-28-87 \\
1-05-88 \\
4-13-88 \\
7-24-88\end{array}$ & $\begin{array}{l}1,900 \\
1,390 \\
1,800 \\
1,970 \\
1,750 \\
1,950 \\
2,130\end{array}$ & $\begin{array}{l}7.6 \\
7.8 \\
7.5 \\
7.7 \\
7.5 \\
7.4 \\
7.6\end{array}$ & $\begin{array}{l}17.5 \\
17.0 \\
18.0 \\
18.0 \\
18.0 \\
18.0 \\
18.0\end{array}$ & $\begin{array}{l}190 \\
190 \\
170 \\
150 \\
160 \\
180 \\
210\end{array}$ & $\begin{array}{r}92 \\
84 \\
82 \\
79 \\
78 \\
87 \\
110\end{array}$ & $\begin{array}{r}100 \\
110 \\
110 \\
130 \\
97 \\
99 \\
140\end{array}$ \\
\hline $26 \mathrm{~L} 2^{1}$ & $\begin{array}{r}5-06-87 \\
6-23-87 \\
9-11-87 \\
10-28-87 \\
1-05-88 \\
4-12-88 \\
7-23-88\end{array}$ & $\begin{array}{r}1,090 \\
1,080 \\
1,090 \\
1,120 \\
1,160 \\
1,110\end{array}$ & $\begin{array}{l}7.5 \\
7.7 \\
7.2 \\
7.5 \\
7.4 \\
7.4 \\
7.4\end{array}$ & $\begin{array}{l}18.0 \\
18.5 \\
18.5 \\
17.5 \\
\overline{18.0} \\
17.5\end{array}$ & $\begin{array}{l}68 \\
71 \\
67 \\
69 \\
57 \\
66 \\
65\end{array}$ & $\begin{array}{l}48 \\
48 \\
46 \\
46 \\
44 \\
46 \\
46\end{array}$ & $\begin{array}{l}84 \\
85 \\
82 \\
82 \\
84 \\
81 \\
81\end{array}$ \\
\hline \multicolumn{8}{|c|}{ Upper Aquifer--Main Zone } \\
\hline $7 \mathrm{~N} / 34 \mathrm{~W}-19 \mathrm{~J} 1$ & $6-30-82$ & 1,290 & 7.7 & 19.5 & 110 & 28 & 120 \\
\hline $22 \mathrm{Q} 7$ & $12-21-88$ & 1,500 & 7.6 & 18.0 & 86 & 39 & 230 \\
\hline $26 \mathrm{~N} 6$ & $12-20-88$ & 1,110 & 7.6 & 17.5 & 110 & 59 & 75 \\
\hline $27 \mathrm{E} 1$ & $\begin{array}{l}00-00-35 \\
10-02-53\end{array}$ & 1,690 & $\begin{array}{l}-- \\
--\end{array}$ & $\begin{array}{l}-- \\
--\end{array}$ & $\begin{array}{l}120 \\
170\end{array}$ & $\begin{array}{l}67 \\
86\end{array}$ & $\begin{array}{r}86 \\
110\end{array}$ \\
\hline $27 \mathrm{G5}$ & $5-07-87$ & 1,500 & 7.5 & 19.0 & 150 & 74 & 89 \\
\hline $27 \mathrm{~K} 7$ & $1-19-88$ & 1,540 & -- & -- & 150 & 72 & 110 \\
\hline $27 \mathrm{~N} 5$ & $1-07-88$ & -- & 7.2 & 18.0 & 270 & 140 & 120 \\
\hline 27P5 & $\begin{array}{r}5-02-67 \\
8-28-69 \\
10-30-70 \\
3-17-72 \\
10-15-73 \\
5-15-74 \\
10-15-75 \\
7-15-76 \\
10-15-77 \\
3-15-78 \\
7-17-81 \\
8-22-84 \\
8-22-85 \\
7-15-86 \\
6-24-87 \\
7-20-88\end{array}$ & $\begin{array}{r}-- \\
-- \\
-- \\
-- \\
-- \\
-- \\
-- \\
-- \\
-- \\
-- \\
-- \\
1,560 \\
1,880 \\
1,820 \\
1,990 \\
1,820\end{array}$ & $\begin{array}{l}-- \\
-- \\
-- \\
-- \\
-- \\
-- \\
-- \\
-- \\
-- \\
- \\
7.6 \\
7.2 \\
7.4 \\
7.5 \\
7.5 \\
7.4\end{array}$ & $\begin{array}{l}17.0 \\
18.0 \\
17.0 \\
17.0 \\
18.0 \\
17.0 \\
17.0 \\
17.0 \\
17.0 \\
17.0 \\
17.0 \\
18.0 \\
18.0 \\
18.0 \\
18.0 \\
18.0\end{array}$ & $\begin{array}{l}190 \\
180 \\
180 \\
180 \\
180 \\
180 \\
170 \\
190 \\
210 \\
190 \\
190 \\
230 \\
240 \\
200 \\
190 \\
220\end{array}$ & $\begin{array}{r}81 \\
82 \\
84 \\
87 \\
84 \\
74 \\
78 \\
79 \\
87 \\
88 \\
96 \\
110 \\
96 \\
100 \\
95 \\
110\end{array}$ & $\begin{array}{r}100 \\
110 \\
100 \\
100 \\
110 \\
110 \\
83 \\
110 \\
110 \\
110 \\
100 \\
120 \\
130 \\
110 \\
110 \\
110\end{array}$ \\
\hline
\end{tabular}

Footnotes at end of table. 


\begin{tabular}{|c|c|c|c|c|c|c|c|}
\hline $\begin{array}{l}\text { Potassium, } \\
\text { dissolved } \\
(\mathrm{mg} / \mathrm{L})\end{array}$ & $\begin{array}{l}\text { Alkalinity, } \\
\text { total, field } \\
\text { (mg/L as } \\
\left.\mathrm{CaCO}_{3}\right)\end{array}$ & $\begin{array}{c}\text { Sulfate, } \\
\text { dissolved } \\
(\mathrm{mg} / \mathrm{L})\end{array}$ & $\begin{array}{c}\text { Chloride, } \\
\text { dissolved } \\
(\mathrm{mg} / \mathrm{L})\end{array}$ & $\begin{array}{l}\text { Solids, sum of } \\
\text { constituents, } \\
\text { dissolved } \\
(\mathrm{mg} / \mathrm{L})\end{array}$ & $\begin{array}{c}\text { Nitrogen, } \\
\text { nitrite plus nitrate, } \\
\text { dissolved } \\
(\mathrm{mg} / \mathrm{L} \text { as } \mathrm{N})\end{array}$ & $\begin{array}{l}\text { Boron, } \\
\text { dissolved } \\
(\mu \mathrm{g} / \mathrm{L})\end{array}$ & $\begin{array}{c}\text { Manganese, } \\
\text { dissolved } \\
(\mu \mathrm{g} / \mathrm{L})\end{array}$ \\
\hline \multicolumn{8}{|c|}{ Upper Aquifer--Middle Zone--Continued } \\
\hline $\begin{array}{l}5.1 \\
5.3 \\
5.1 \\
1.5 \\
5.1 \\
3.9 \\
4.8\end{array}$ & $\begin{array}{l}375 \\
380 \\
389 \\
385 \\
394 \\
370 \\
383\end{array}$ & $\begin{array}{l}350 \\
440 \\
370 \\
430 \\
290 \\
380 \\
620\end{array}$ & $\begin{array}{l}210 \\
220 \\
190 \\
250 \\
180 \\
200 \\
270\end{array}$ & $\begin{array}{l}1,210 \\
1,320 \\
1,200 \\
1,310 \\
1,080 \\
1,210 \\
1,630\end{array}$ & $\begin{array}{r}<0.10 \\
.58 \\
.67 \\
.44 \\
<.10 \\
.65 \\
2.2\end{array}$ & $\begin{array}{l}290 \\
360 \\
350 \\
390 \\
280 \\
290 \\
430\end{array}$ & $\begin{array}{l}590 \\
440 \\
340 \\
320 \\
300 \\
360 \\
380\end{array}$ \\
\hline $\begin{array}{l}2.8 \\
2.9 \\
2.8 \\
5.7 \\
3.4 \\
2.7 \\
2.6\end{array}$ & $\begin{array}{l}218 \\
226 \\
228 \\
216 \\
210 \\
212 \\
228\end{array}$ & $\begin{array}{l}130 \\
120 \\
130 \\
130 \\
120 \\
120 \\
120\end{array}$ & $\begin{array}{l}160 \\
150 \\
150 \\
150 \\
150 \\
150 \\
150\end{array}$ & $\begin{array}{l}664 \\
654 \\
654 \\
652 \\
625 \\
631 \\
644\end{array}$ & $\begin{array}{r}.35 \\
.19 \\
.26 \\
.20 \\
.28 \\
-- \\
.83\end{array}$ & $\begin{array}{l}130 \\
130 \\
130 \\
130 \\
120 \\
130 \\
110\end{array}$ & $\begin{array}{l}1,300 \\
1,400 \\
1,300 \\
1,400 \\
1,200 \\
1,400 \\
1,400\end{array}$ \\
\hline \multicolumn{8}{|c|}{ Upper Aquifer--Main Zone--Continued } \\
\hline 6.2 & 250 & 110 & 220 & 787 & 0.23 & 210 & 360 \\
\hline 6.2 & 311 & 390 & 150 & 1,120 & .55 & 310 & 910 \\
\hline 3.0 & 239 & 350 & 76 & 854 & $<.10$ & 390 & 720 \\
\hline$\overline{5} .5$ & $\begin{array}{l}281 \\
388\end{array}$ & $\begin{array}{l}340 \\
440\end{array}$ & $\begin{array}{r}87 \\
100\end{array}$ & $\begin{array}{r}900 \\
1,170\end{array}$ & -- & $\begin{array}{r}50 \\
700\end{array}$ & -- \\
\hline 3.7 & 331 & 410 & 110 & 1,080 & $<.10$ & 480 & 810 \\
\hline 5.0 & 345 & 350 & 130 & 1,030 & .40 & -- & -- \\
\hline- & L414 & 820 & 150 & ${ }^{3} 1,749$ & .16 & -- & 930 \\
\hline $\begin{array}{l}4.3 \\
2.7 \\
2.6 \\
3.5 \\
4.4 \\
4.4 \\
4.3 \\
4.3 \\
4.8 \\
4.7 \\
4.7 \\
5.0 \\
5.0 \\
4.7 \\
4.8 \\
5.2\end{array}$ & $\begin{array}{r}310 \\
316 \\
342 \\
356 \\
\text { L342 } \\
\text { L352 } \\
\text { L338 } \\
\text { L376 } \\
\text { L382 } \\
\text { L380 } \\
\text { L410 } \\
464 \\
454 \\
425 \\
443 \\
434\end{array}$ & $\begin{array}{l}530 \\
530 \\
520 \\
510 \\
490 \\
480 \\
480 \\
500 \\
540 \\
520 \\
490 \\
560 \\
550 \\
580 \\
560 \\
610\end{array}$ & $\begin{array}{r}100 \\
100 \\
100 \\
92 \\
95 \\
95 \\
100 \\
100 \\
110 \\
110 \\
120 \\
140 \\
130 \\
120 \\
130 \\
130\end{array}$ & $\begin{array}{l}1,220 \\
1,190 \\
1,200 \\
1,230 \\
1,200 \\
1,190 \\
1,160 \\
1,250 \\
1,330 \\
1,290 \\
1,290 \\
1,480 \\
1,460 \\
1,410 \\
1,400 \\
1,490\end{array}$ & $\begin{array}{l}-- \\
-- \\
-- \\
-- \\
-- \\
.00 \\
.00 \\
-- \\
.10 \\
.10 \\
.25 \\
<.10 \\
<.10 \\
<.10 \\
<.10 \\
<.10\end{array}$ & $\begin{array}{r}0 \\
-- \\
520 \\
-- \\
- \\
520 \\
330 \\
410 \\
520 \\
470 \\
520 \\
540 \\
510 \\
530 \\
500\end{array}$ & $\begin{array}{r}1,000 \\
540 \\
580 \\
670 \\
670 \\
500 \\
500 \\
830 \\
670 \\
740 \\
720 \\
770 \\
830 \\
830 \\
830 \\
880\end{array}$ \\
\hline
\end{tabular}


Table 9. Chemical analyses of ground water in the Lompoc area--Continued

\begin{tabular}{|c|c|c|c|c|c|c|c|}
\hline $\begin{array}{c}\text { State well } \\
\text { No. }\end{array}$ & Date & $\begin{array}{c}\text { Specific } \\
\text { conductance } \\
(\mu \mathrm{S} / \mathrm{cm})\end{array}$ & $\begin{array}{c}\mathrm{pH} \\
\text { (standard } \\
\text { units) }\end{array}$ & $\begin{array}{c}\text { Temperature, } \\
\text { water } \\
\left({ }^{\circ} \mathrm{C}\right)\end{array}$ & $\begin{array}{l}\text { Calcium, } \\
\text { dissolved } \\
(\mathrm{mg} / \mathrm{L})\end{array}$ & $\begin{array}{c}\text { Magnesium, } \\
\text { dissolved } \\
(\mathrm{mg} / \mathrm{L})\end{array}$ & $\begin{array}{c}\text { Sodium, } \\
\text { dissolved } \\
(\mathrm{mg} / \mathrm{L})\end{array}$ \\
\hline \multicolumn{8}{|c|}{ Upper Aquifer--Main Zone--Continued } \\
\hline $7 \mathrm{~N} / 34 \mathrm{~W}-27 \mathrm{Q} 2$ & $\begin{array}{r}8-14-69 \\
12-15-69 \\
4-16-70 \\
10-16-70 \\
3-13-72 \\
9-15-73 \\
5-15-74 \\
10-15-75 \\
10-15-76 \\
11-15-77 \\
3-15-78 \\
3-15-79 \\
1-15-80 \\
4-15-81 \\
2-15-82 \\
4-15-83 \\
2-15-84 \\
1-07-88\end{array}$ & $\begin{array}{r}-- \\
1,190 \\
-- \\
-- \\
-- \\
-- \\
-- \\
-- \\
-- \\
-- \\
-- \\
-- \\
-- \\
-- \\
-- \\
-- \\
--\end{array}$ & $\begin{array}{l}-- \\
-- \\
-- \\
-- \\
-- \\
7.2 \\
7.5 \\
7.3 \\
7.3 \\
7.5 \\
7.3 \\
7.3 \\
7.3 \\
7.3 \\
7.3 \\
7.4 \\
7.4 \\
7.3\end{array}$ & $\begin{array}{l}18.0 \\
20.0 \\
16.5 \\
19.0 \\
17.0 \\
17.0 \\
17.0 \\
17.0 \\
18.0 \\
17.0 \\
17.0 \\
18.0 \\
16.0 \\
16.0 \\
16.0 \\
17.0 \\
16.0 \\
17.0\end{array}$ & $\begin{array}{r}140 \\
130 \\
26 \\
140 \\
140 \\
160 \\
150 \\
150 \\
150 \\
150 \\
140 \\
150 \\
98 \\
140 \\
150 \\
140 \\
140 \\
160\end{array}$ & $\begin{array}{l}62 \\
63 \\
22 \\
67 \\
69 \\
71 \\
70 \\
65 \\
68 \\
75 \\
69 \\
68 \\
92 \\
72 \\
73 \\
69 \\
79 \\
79\end{array}$ & $\begin{array}{r}80 \\
76 \\
180 \\
75 \\
78 \\
78 \\
82 \\
81 \\
82 \\
82 \\
86 \\
82 \\
85 \\
83 \\
78 \\
85 \\
86 \\
86\end{array}$ \\
\hline 28B4 & $12-20-88$ & 1,400 & 7.4 & 18.0 & 140 & 59 & 110 \\
\hline $28 \mathrm{M} 2^{1}$ & $\begin{array}{l}1-06-88 \\
4-14-88 \\
7-22-88\end{array}$ & $\begin{array}{l}2,200 \\
2,240 \\
2,170\end{array}$ & $\begin{array}{l}7.4 \\
7.3 \\
7.5\end{array}$ & $\begin{array}{l}17.0 \\
18.0 \\
18.5\end{array}$ & $\begin{array}{l}210 \\
210 \\
210\end{array}$ & $\begin{array}{r}99 \\
110 \\
100\end{array}$ & $\begin{array}{l}170 \\
170 \\
160\end{array}$ \\
\hline $29 \mathrm{~F} 1^{1}$ & $\begin{array}{r}10-30-87 \\
1-06-88 \\
4-13-88 \\
7-22-88\end{array}$ & $\begin{array}{l}1,950 \\
1,840 \\
1,870 \\
1,950\end{array}$ & $\begin{array}{l}7.9 \\
7.5 \\
7.4 \\
7.5\end{array}$ & $\begin{array}{l}17.5 \\
18.0 \\
18.5 \\
18.5\end{array}$ & $\begin{array}{l}140 \\
150 \\
140 \\
120\end{array}$ & $\begin{array}{l}73 \\
72 \\
70 \\
67\end{array}$ & $\begin{array}{l}180 \\
180 \\
190 \\
200\end{array}$ \\
\hline $29 J 1$ & $6-02-83$ & 2,250 & 7.3 & 18.0 & 240 & 110 & 170 \\
\hline $29 \mathrm{~N}^{1}$ & $\begin{array}{r}3-13-87 \\
5-05-87 \\
6-25-87 \\
9-10-87 \\
10-28-87 \\
1-06-88 \\
4-12-88 \\
7-23-88\end{array}$ & $\begin{array}{l}2,580 \\
2,690 \\
2,680 \\
2,670 \\
2,730 \\
3,260 \\
2,510 \\
2,600\end{array}$ & $\begin{array}{l}7.7 \\
7.5 \\
7.4 \\
6.9 \\
7.6 \\
7.5 \\
7.3 \\
7.8\end{array}$ & $\begin{array}{l}-\overline{17.5} \\
-- \\
18.0 \\
18.0 \\
15.5 \\
18.0 \\
18.0\end{array}$ & $\begin{array}{l}270 \\
260 \\
290 \\
240 \\
260 \\
280 \\
270 \\
290\end{array}$ & $\begin{array}{l}140 \\
140 \\
140 \\
130 \\
140 \\
140 \\
150 \\
160\end{array}$ & $\begin{array}{l}150 \\
140 \\
130 \\
140 \\
140 \\
140 \\
140 \\
130\end{array}$ \\
\hline $30 \mathrm{~L} 5$ & $6-01-83$ & 2,600 & 7.4 & 17.0 & 280 & 140 & 150 \\
\hline $31 \mathrm{~A} 2$ & $\begin{array}{l}4-12-41 \\
9-25-53 \\
5-18-64 \\
9-29-64 \\
4-16-70 \\
3-15-72\end{array}$ & $\begin{array}{l}1,790 \\
2,190 \\
2,630 \\
2,400 \\
2,330 \\
2,540\end{array}$ & $\begin{array}{l}-- \\
-- \\
-- \\
-- \\
-- \\
--\end{array}$ & $\begin{array}{c}- \\
19.0 \\
16.0 \\
-\overline{16.0} \\
17.0\end{array}$ & $\begin{array}{l}130 \\
240 \\
300 \\
270 \\
210 \\
290\end{array}$ & $\begin{array}{r}50 \\
130 \\
150 \\
150 \\
170 \\
150\end{array}$ & $\begin{array}{l}190 \\
100 \\
130 \\
130 \\
120 \\
140\end{array}$ \\
\hline
\end{tabular}

Footnotes at end of table. 


\begin{tabular}{|c|c|c|c|c|c|c|c|}
\hline $\begin{array}{l}\text { Potassium, } \\
\text { dissolved } \\
(\mathrm{mg} / \mathrm{L})\end{array}$ & $\begin{array}{l}\text { Alkalinity, } \\
\text { total, field } \\
(\mathrm{mg} / \mathrm{L} \text { as } \\
\left.\mathrm{CaCO}_{3}\right)\end{array}$ & $\begin{array}{l}\text { Sulfate, } \\
\text { dissolved } \\
(\mathrm{mg} / \mathrm{L})\end{array}$ & $\begin{array}{l}\text { Chloride, } \\
\text { dissolved } \\
\text { (mg/L) }\end{array}$ & $\begin{array}{l}\text { Solids, sum of } \\
\text { constituents, } \\
\text { dissolved } \\
(\mathrm{mg} / \mathrm{L})\end{array}$ & $\begin{array}{l}\text { Nitrogen, } \\
\text { nitrite plus nitrate, } \\
\text { dissolved } \\
(\mathrm{mg} / \mathrm{L} \text { as } \mathrm{N})\end{array}$ & $\begin{array}{l}\text { Boron, } \\
\text { dissolved } \\
(\mu \mathrm{g} / \mathrm{L})\end{array}$ & $\begin{array}{l}\text { Manganese, } \\
\text { dissolved } \\
(\mu \mathrm{g} / \mathrm{L})\end{array}$ \\
\hline \multicolumn{8}{|c|}{ Upper Aquifer--Main Zone--Continued } \\
\hline $\begin{array}{l}6.4 \\
2.2 \\
6.0 \\
2.4 \\
2.7 \\
3.5 \\
3.4 \\
3.7 \\
3.6 \\
4.1 \\
3.5 \\
3.5 \\
3.4 \\
3.7 \\
5.2 \\
5.0 \\
5.3 \\
--\end{array}$ & $\begin{array}{r}303 \\
293 \\
69 \\
303 \\
300 \\
\text { L300 } \\
\text { L303 } \\
\text { L298 } \\
304 \\
\text { L303 } \\
\text { L303 } \\
\text { L274 } \\
\text { L283 } \\
\text { L286 } \\
\text { L310 } \\
\text { L271 } \\
\text { L271 } \\
\text { L320 }\end{array}$ & $\begin{array}{l}380 \\
430 \\
360 \\
430 \\
390 \\
400 \\
390 \\
390 \\
400 \\
440 \\
380 \\
360 \\
350 \\
420 \\
370 \\
410 \\
400 \\
390\end{array}$ & $\begin{array}{r}110 \\
78 \\
84 \\
80 \\
69 \\
84 \\
85 \\
78 \\
85 \\
89 \\
87 \\
80 \\
79 \\
84 \\
87 \\
91 \\
85 \\
96\end{array}$ & $\begin{array}{r}962 \\
961 \\
718 \\
975 \\
971 \\
1,010 \\
998 \\
982 \\
823 \\
1,070 \\
996 \\
954 \\
885 \\
1,010 \\
986 \\
1,010 \\
1,000 \\
31,004\end{array}$ & $\begin{array}{l}-- \\
-- \\
-- \\
-- \\
- \\
0.00 \\
.03 \\
.00 \\
.00 \\
.10 \\
.10 \\
.10 \\
.10 \\
.10 \\
.10 \\
.10 \\
.10 \\
<.10\end{array}$ & $\begin{array}{r}-- \\
-- \\
120 \\
-- \\
350 \\
610 \\
290 \\
560 \\
270 \\
370 \\
520 \\
480 \\
460 \\
640 \\
460 \\
260 \\
440 \\
--\end{array}$ & $\begin{array}{r}670 \\
620 \\
-- \\
-- \\
580 \\
460 \\
500 \\
500 \\
500 \\
750 \\
580 \\
520 \\
480 \\
580 \\
550 \\
630 \\
560 \\
580\end{array}$ \\
\hline 4.0 & 332 & 310 & 160 & 1,030 & .31 & 350 & 530 \\
\hline $\begin{array}{l}7.0 \\
5.5 \\
5.8\end{array}$ & $\begin{array}{l}425 \\
424 \\
422\end{array}$ & $\begin{array}{l}660 \\
740 \\
700\end{array}$ & $\begin{array}{l}200 \\
150 \\
160\end{array}$ & $\begin{array}{l}1,650 \\
1,690 \\
1,640\end{array}$ & $\begin{array}{l}<.10 \\
<.10 \\
<.10\end{array}$ & $\begin{array}{l}530 \\
730 \\
660\end{array}$ & $\begin{array}{r}1,100 \\
1,100 \\
950\end{array}$ \\
\hline $\begin{array}{l}5.0 \\
7.2 \\
5.7 \\
6.2\end{array}$ & $\begin{array}{l}360 \\
394 \\
386 \\
348\end{array}$ & $\begin{array}{l}470 \\
420 \\
430 \\
410\end{array}$ & $\begin{array}{l}240 \\
200 \\
200 \\
200\end{array}$ & $\begin{array}{l}1,360 \\
1,310 \\
1,310 \\
1,250\end{array}$ & $\begin{array}{l}<.10 \\
<.10 \\
.12 \\
<.10\end{array}$ & $\begin{array}{l}550 \\
570 \\
600 \\
550\end{array}$ & $\begin{array}{l}620 \\
670 \\
630 \\
570\end{array}$ \\
\hline 5.4 & 390 & 760 & 180 & 1,740 & $<.10$ & 820 & -- \\
\hline $\begin{array}{l}5.8 \\
5.4 \\
5.3 \\
5.7 \\
5.8 \\
6.2 \\
5.0 \\
5.6\end{array}$ & $\begin{array}{l}466 \\
478 \\
490 \\
490 \\
433 \\
496 \\
482 \\
498\end{array}$ & $\begin{array}{l}940 \\
850 \\
930 \\
910 \\
900 \\
960 \\
990 \\
960\end{array}$ & $\begin{array}{l}190 \\
200 \\
190 \\
200 \\
180 \\
190 \\
200 \\
200\end{array}$ & $\begin{array}{l}2,020 \\
1,930 \\
2,020 \\
1,960 \\
1,930 \\
2,060 \\
2,090 \\
2,090\end{array}$ & $\begin{array}{r}.15 \\
<.10 \\
<.10 \\
<.10 \\
<.10 \\
<.10 \\
<.10 \\
<.10\end{array}$ & $\begin{array}{l}620 \\
630 \\
650 \\
650 \\
670 \\
640 \\
660 \\
610\end{array}$ & $\begin{array}{l}1,500 \\
1,400 \\
1,500 \\
1,800 \\
1,600 \\
1,400 \\
1,500 \\
1,500\end{array}$ \\
\hline 5.9 & 470 & 830 & 220 & 1,950 & $<.10$ & 730 & -- \\
\hline $\begin{array}{l}-- \\
3.5 \\
5.9 \\
6.0 \\
5.0 \\
4.6\end{array}$ & $\begin{array}{l}445 \\
458 \\
455 \\
458 \\
330 \\
449\end{array}$ & $\begin{array}{l}340 \\
610 \\
850 \\
800 \\
780 \\
820\end{array}$ & $\begin{array}{l}100 \\
180 \\
230 \\
210 \\
220 \\
210\end{array}$ & $\begin{array}{l}1,100 \\
1,570 \\
1,940 \\
1,850 \\
1,690 \\
1,870\end{array}$ & $\begin{array}{l}-- \\
-- \\
-- \\
-- \\
--\end{array}$ & $\begin{array}{r}-- \\
680 \\
710 \\
520 \\
660 \\
560\end{array}$ & $\begin{array}{l}-- \\
-- \\
-- \\
-- \\
-- \\
--\end{array}$ \\
\hline
\end{tabular}


Table 9. Chemical analyses of ground water in the Lompoc area--Continued

\begin{tabular}{|c|c|c|c|c|c|c|c|}
\hline $\begin{array}{l}\text { State well } \\
\text { No. }\end{array}$ & Date & $\begin{array}{c}\text { Specific } \\
\text { conductance } \\
(\mu \mathrm{S} / \mathrm{cm})\end{array}$ & $\begin{array}{c}\mathrm{pH} \\
\text { (standard } \\
\text { units) }\end{array}$ & $\begin{array}{c}\text { Temperature, } \\
\text { water } \\
\left({ }^{\circ} \mathrm{C}\right)\end{array}$ & $\begin{array}{l}\text { Calcium, } \\
\text { dissolved } \\
(\mathrm{mg} / \mathrm{L})\end{array}$ & $\begin{array}{c}\text { Magnesium, } \\
\text { dissolved } \\
(\mathrm{mg} / \mathrm{L})\end{array}$ & $\begin{array}{l}\text { Sodium, } \\
\text { dissolved } \\
(\mathrm{mg} / \mathrm{L})\end{array}$ \\
\hline \multicolumn{8}{|c|}{ Upper Aquifer--Main Zone--Continued } \\
\hline $7 N / 34 W-31 A 3$ & $5-15-24$ & -- & -- & -- & 140 & 74 & 81 \\
\hline $34 \mathrm{~A} 4$ & $\begin{array}{r}2-15-61 \\
5-02-67 \\
9-03-68 \\
8-29-69 \\
12-16-69 \\
10-29-70 \\
12-15-71 \\
8-15-73 \\
5-15-74 \\
10-15-75 \\
7-15-76 \\
11-15-77 \\
3-15-78 \\
2-15-79 \\
1-15-80 \\
4-15-81 \\
2-15-82 \\
2-15-83 \\
2-15-84 \\
1-07-88\end{array}$ & $\begin{array}{r}1,500 \\
-- \\
-- \\
-- \\
-- \\
-- \\
-- \\
-- \\
-- \\
-- \\
-- \\
-- \\
-- \\
-- \\
-- \\
-- \\
-- \\
-- \\
-- \\
--\end{array}$ & $\begin{array}{l}-- \\
-- \\
-- \\
-- \\
-- \\
-- \\
7.4 \\
7.3 \\
7.4 \\
7.5 \\
7.3 \\
7.3 \\
7.4 \\
7.4 \\
7.4 \\
7.4 \\
7.4 \\
7.4 \\
7.5 \\
7.3\end{array}$ & $\begin{array}{l}-- \\
17.0 \\
17.0 \\
17.0 \\
17.0 \\
19.0 \\
16.0 \\
16.0 \\
18.0 \\
17.0 \\
17.0 \\
16.0 \\
15.5 \\
16.0 \\
17.0 \\
16.0 \\
16.0 \\
17.0 \\
16.0 \\
17.0\end{array}$ & $\begin{array}{l}120 \\
150 \\
160 \\
130 \\
130 \\
130 \\
140 \\
160 \\
160 \\
150 \\
140 \\
150 \\
150 \\
140 \\
140 \\
130 \\
130 \\
150 \\
140 \\
150\end{array}$ & $\begin{array}{l}83 \\
54 \\
50 \\
61 \\
64 \\
62 \\
65 \\
71 \\
61 \\
66 \\
67 \\
68 \\
68 \\
64 \\
68 \\
61 \\
66 \\
70 \\
75 \\
74\end{array}$ & $\begin{array}{r}74 \\
98 \\
88 \\
80 \\
77 \\
75 \\
79 \\
82 \\
85 \\
85 \\
91 \\
97 \\
90 \\
86 \\
87 \\
82 \\
81 \\
100 \\
92 \\
93\end{array}$ \\
\hline $34 \mathrm{~B} 1$ & $\begin{array}{r}5-23-60 \\
1-30-63 \\
2-08-64 \\
5-08-67 \\
9-09-69 \\
12-26-69 \\
10-20-70 \\
12-07-71 \\
8-15-73 \\
5-15-74 \\
10-15-75 \\
10-15-76 \\
10-15-77 \\
3-15-78 \\
2-15-79 \\
2-15-80 \\
1-15-81 \\
2-15-82 \\
6-15-83 \\
1-07-88\end{array}$ & $\begin{array}{r}-- \\
1,600 \\
1,290 \\
-- \\
-- \\
-- \\
-- \\
-- \\
-- \\
-- \\
-- \\
-- \\
-- \\
-- \\
-- \\
-- \\
-- \\
-- \\
-- \\
--\end{array}$ & $\begin{array}{l}-- \\
-- \\
-- \\
-- \\
-- \\
-- \\
-- \\
- \\
7.3 \\
7.3 \\
7.3 \\
7.4 \\
7.4 \\
7.3 \\
7.3 \\
7.4 \\
7.3 \\
7.3 \\
7.3 \\
7.3\end{array}$ & $\begin{array}{c}-- \\
-- \\
-- \\
17.0 \\
17.0 \\
-- \\
18.5 \\
17.0 \\
17.0 \\
17.0 \\
17.0 \\
17.0 \\
17.0 \\
17.0 \\
17.0 \\
17.0 \\
16.0 \\
17.0 \\
17.0 \\
16.0\end{array}$ & $\begin{array}{l}150 \\
180 \\
130 \\
140 \\
140 \\
140 \\
150 \\
140 \\
150 \\
160 \\
160 \\
150 \\
150 \\
140 \\
160 \\
150 \\
150 \\
150 \\
140 \\
140\end{array}$ & $\begin{array}{l}68 \\
99 \\
70 \\
64 \\
67 \\
59 \\
68 \\
68 \\
69 \\
64 \\
70 \\
70 \\
71 \\
72 \\
76 \\
73 \\
71 \\
69 \\
66 \\
72\end{array}$ & $\begin{array}{r}130 \\
72 \\
19 \\
89 \\
80 \\
-- \\
77 \\
75 \\
80 \\
85 \\
89 \\
86 \\
85 \\
83 \\
85 \\
86 \\
86 \\
87 \\
91 \\
95\end{array}$ \\
\hline
\end{tabular}

Footnotes at end of table. 


\begin{tabular}{|c|c|c|c|c|c|c|c|}
\hline $\begin{array}{l}\text { Potassium, } \\
\text { dissolved } \\
(\mathrm{mg} / \mathrm{L})\end{array}$ & $\begin{array}{c}\text { Alkalinity, } \\
\text { total, field } \\
(\mathrm{mg} / \mathrm{L} \text { as } \\
\left.\mathrm{CaCO}_{3}\right)\end{array}$ & $\begin{array}{c}\text { Sulfate, } \\
\text { dissolved } \\
(\mathrm{mg} / \mathrm{L})\end{array}$ & $\begin{array}{c}\text { Chloride, } \\
\text { dissolved } \\
\text { (mg/L) }\end{array}$ & $\begin{array}{l}\text { Solids, sum of } \\
\text { constituents, } \\
\text { dissolved } \\
(\mathrm{mg} / \mathrm{L})\end{array}$ & $\begin{array}{l}\text { Nitrogen, } \\
\text { nitrite plus nitrate, } \\
\text { dissolved } \\
(\mathrm{mg} / \mathrm{L} \text { as } \mathrm{N})\end{array}$ & $\begin{array}{l}\text { Boron, } \\
\text { dissolved } \\
(\mu \mathrm{g} / \mathrm{L})\end{array}$ & $\begin{array}{c}\text { Manganese, } \\
\text { dissolved } \\
(\mu \mathrm{g} / \mathrm{L})\end{array}$ \\
\hline
\end{tabular}

\begin{tabular}{|c|c|c|c|c|c|c|c|}
\hline \multicolumn{8}{|c|}{ Upper Aquifer--Main Zone--Continued } \\
\hline-- & 536 & 260 & 92 & 1,030 & -- & -- & -- \\
\hline 3.7 & 291 & 380 & 94 & 949 & -- & 230 & -- \\
\hline 4.2 & 277 & 370 & 100 & 983 & -- & 0 & 580 \\
\hline 3.8 & 289 & 380 & 99 & 952 & -- & 0 & 550 \\
\hline 2.7 & 268 & 410 & 100 & 951 & -- & -- & 420 \\
\hline 2.3 & 273 & 430 & 84 & 949 & -- & -- & 420 \\
\hline 2.4 & 269 & 410 & 84 & 929 & -- & -- & 330 \\
\hline 2.9 & L260 & 380 & 86 & 947 & 0.06 & 370 & 420 \\
\hline 3.9 & L278 & 430 & 100 & 1,060 & .00 & 580 & 460 \\
\hline 3.9 & L272 & 410 & 90 & 1,010 & .03 & 500 & 500 \\
\hline 3.9 & L269 & 290 & 90 & 885 & .00 & 510 & 420 \\
\hline 3.8 & L272 & 390 & 100 & 996 & .00 & 350 & 380 \\
\hline 4.1 & L284 & 400 & 100 & 1,040 & .10 & 370 & 500 \\
\hline 39 & L288 & 390 & 110 & 1,060 & .10 & 500 & 620 \\
\hline 3.7 & L261 & 380 & 92 & 960 & .10 & 450 & 510 \\
\hline 3.0 & L260 & 340 & 97 & 895 & .10 & 480 & 530 \\
\hline 3.8 & L243 & 390 & 89 & 949 & .10 & 80 & 430 \\
\hline 7.4 & L275 & 370 & 100 & 969 & .10 & 440 & 260 \\
\hline 7.5 & L273 & 420 & 100 & 1,060 & .10 & 280 & 540 \\
\hline 5.5 & $\mathrm{~L} 272$ & 370 & 90 & 978 & .10 & 400 & 500 \\
\hline-- & $\mathrm{L} 284$ & 380 & 110 & 3978 & $<.10$ & - & 490 \\
\hline-- & 263 & 500 & 100 & -- & -- & -- & -- \\
\hline-- & 352 & 460 & 110 & -- & -- & -- & 1,000 \\
\hline -- & 269 & 250 & 99 & -- & -- & -- & 1,900 \\
\hline 4.0 & 273 & 410 & 94 & 999 & -- & 0 & 580 \\
\hline 2.8 & 286 & 420 & 100 & 989 & -- & -- & 580 \\
\hline-- & 278 & 430 & 87 & 1,100 & -- & --. & 500 \\
\hline 2.8 & 315 & 450 & 89 & 1,020 & -- & - & 420 \\
\hline 2.9 & 283 & 410 & 81 & 986 & -- & 350 & 430 \\
\hline 3.9 & L280 & 400 & 96 & 1,010 & .00 & 340 & 500 \\
\hline 4.1 & L296 & 420 & 90 & 1,000 & .00 & 370 & 460 \\
\hline 4.1 & L299 & 400 & 86 & 1,030 & .00 & 510 & 500 \\
\hline 4.2 & L300 & 400 & 91 & 989 & .00 & 410 & 500 \\
\hline 4.2 & L293 & 410 & 84 & 1,030 & .10 & -. & 600 \\
\hline 4.1 & L267 & 370 & 91 & 964 & .10 & 520 & 500 \\
\hline 4.2 & L309 & 400 & 94 & 1,050 & .10 & 460 & 520 \\
\hline 4.2 & L306 & 400 & 96 & 1,000 & .10 & 380 & 540 \\
\hline 4.1 & L283 & 390 & 92 & 1,010 & .10 & 480 & 550 \\
\hline 6.8 & L301 & 380 & 89 & 1,010 & .10 & 440 & 450 \\
\hline 6.3 & L274 & 370 & 89 & 970 & .10 & 340 & 440 \\
\hline-- & L285 & 370 & 100 & ${ }^{3} 948$ & $<.10$ & -- & -. \\
\hline
\end{tabular}


Table 9. Chemical analyses of ground water in the Lompoc area--Continued

\begin{tabular}{|c|c|c|c|c|c|c|c|}
\hline $\begin{array}{l}\text { State well } \\
\text { No. }\end{array}$ & Date & $\begin{array}{c}\text { Specific } \\
\text { conductance } \\
(\mu \mathrm{S} / \mathrm{cm})\end{array}$ & $\begin{array}{c}\mathrm{pH} \\
\text { (standard } \\
\text { units) }\end{array}$ & $\begin{array}{c}\text { Temperature, } \\
\text { water } \\
\left({ }^{\circ} \mathrm{C}\right)\end{array}$ & $\begin{array}{l}\text { Calcium, } \\
\text { dissolved } \\
(\mathrm{mg} / \mathrm{L})\end{array}$ & $\begin{array}{c}\text { Magnesium, } \\
\text { dissolved } \\
(\mathrm{mg} / \mathrm{L})\end{array}$ & $\begin{array}{l}\text { Sodium, } \\
\text { dissolved } \\
(\mathrm{mg} / \mathrm{L})\end{array}$ \\
\hline \multicolumn{8}{|c|}{ Upper Aquifer--Main Zone--Continued } \\
\hline $7 \mathrm{~N} / 34 \mathrm{~W}-34 \mathrm{~F} 6$ & $\begin{array}{r}5-15-67 \\
9-12-69 \\
12-11-69 \\
10-20-70 \\
12-07-71 \\
9-15-73 \\
5-15-74 \\
10-15-75 \\
7-15-76 \\
10-15-77 \\
2-15-80 \\
2-15-81 \\
4-15-82 \\
2-15-83 \\
2-15-84 \\
1-07-88\end{array}$ & $\begin{array}{l}-- \\
-- \\
-- \\
-- \\
-- \\
-- \\
-- \\
-- \\
-- \\
-- \\
-- \\
- \\
-- \\
-- \\
-- \\
--\end{array}$ & $\begin{array}{l}- \\
-- \\
-- \\
-- \\
-- \\
7.3 \\
7.4 \\
7.4 \\
7.3 \\
7.5 \\
7.2 \\
7.3 \\
7.3 \\
7.4 \\
7.3 \\
7.2\end{array}$ & $\begin{array}{l}18.0 \\
18.0 \\
18.0 \\
18.0 \\
16.5 \\
17.0 \\
18.0 \\
17.0 \\
17.0 \\
17.0 \\
17.0 \\
17.0 \\
17.0 \\
18.0 \\
16.0 \\
17.0\end{array}$ & $\begin{array}{l}180 \\
190 \\
190 \\
190 \\
190 \\
200 \\
200 \\
200 \\
210 \\
210 \\
200 \\
210 \\
210 \\
210 \\
210 \\
220\end{array}$ & $\begin{array}{r}80 \\
83 \\
86 \\
89 \\
90 \\
91 \\
84 \\
83 \\
85 \\
94 \\
90 \\
98 \\
97 \\
97 \\
110 \\
110\end{array}$ & $\begin{array}{r}100 \\
100 \\
97 \\
92 \\
84 \\
100 \\
110 \\
96 \\
100 \\
100 \\
110 \\
110 \\
110 \\
110 \\
120 \\
100\end{array}$ \\
\hline $7 \mathrm{~N} / 35 \mathrm{~W}-17 \mathrm{~K} 20$ & $\begin{array}{l}5-20-87 \\
6-23-88\end{array}$ & $\begin{array}{l}3,580 \\
5,290\end{array}$ & $\begin{array}{l}7.3 \\
7.2\end{array}$ & $\begin{array}{l}18.5 \\
19.0\end{array}$ & $\begin{array}{l}190 \\
200\end{array}$ & $\begin{array}{l}150 \\
170\end{array}$ & $\begin{array}{l}690 \\
740\end{array}$ \\
\hline $17 \mathrm{~K} 21^{1}$ & $\begin{array}{l}1-08-88 \\
4-13-88 \\
7-24-88\end{array}$ & $\begin{array}{l}7,390 \\
7,280 \\
6,880\end{array}$ & $\begin{array}{l}7.3 \\
7.2 \\
7.2\end{array}$ & $\begin{array}{l}19.0 \\
18.0 \\
20.0\end{array}$ & $\begin{array}{l}230 \\
280 \\
330\end{array}$ & $\begin{array}{l}210 \\
250 \\
280\end{array}$ & $\begin{array}{l}930 \\
930 \\
980\end{array}$ \\
\hline $21 \mathrm{G} 2$ & $\begin{array}{l}5-08-87 \\
6-23-88\end{array}$ & $\begin{array}{l}2,830 \\
2,360\end{array}$ & $\begin{array}{l}7.5 \\
7.4\end{array}$ & $\begin{array}{l}19.0 \\
19.0\end{array}$ & $\begin{array}{l}240 \\
270\end{array}$ & $\begin{array}{l}120 \\
140\end{array}$ & $\begin{array}{l}200 \\
200\end{array}$ \\
\hline $22 \mathrm{H}^{1}$ & $4-13-88$ & 3,980 & 7.4 & 17.0 & 300 & 150 & 360 \\
\hline $23 \mathrm{~K} 1$ & $5-07-87$ & 2,610 & 7.6 & 19.0 & 260 & 110 & 190 \\
\hline $23 Q^{1}$ & $\begin{array}{r}3-18-87 \\
5-07-87 \\
6-25-87 \\
10-28-87 \\
1-05-88 \\
4-13-88 \\
7-24-88\end{array}$ & $\begin{array}{l}2,860 \\
2,950 \\
3,030 \\
3,150 \\
3,160 \\
3,180 \\
3,040\end{array}$ & $\begin{array}{l}7.5 \\
7.4 \\
7.6 \\
7.5 \\
7.5 \\
7.4 \\
7.3\end{array}$ & $\begin{array}{l}18.5 \\
19.0 \\
18.5 \\
18.5 \\
18.0 \\
18.0 \\
19.0\end{array}$ & $\begin{array}{l}260 \\
270 \\
300 \\
310 \\
240 \\
280 \\
320\end{array}$ & $\begin{array}{l}130 \\
130 \\
140 \\
150 \\
130 \\
140 \\
160\end{array}$ & $\begin{array}{l}180 \\
190 \\
210 \\
210 \\
200 \\
200 \\
220\end{array}$ \\
\hline $24 \mathrm{~K} 5$ & $7-25-88$ & 1,820 & 7.4 & -- & 110 & 41 & 190 \\
\hline $24 \mathrm{P} 3$ & $6-01-83$ & 2,300 & 7.3 & 18.0 & 230 & 110 & 190 \\
\hline $25 \mathrm{D} 3$ & $6-01-83$ & 2,680 & 7.4 & 17.5 & 250 & 120 & 200 \\
\hline $25 \mathrm{~J} 3$ & $7-06-89$ & 2,000 & - & - & - & - & -- \\
\hline $26 \mathrm{~F} 1$ & $\begin{array}{r}00-00-35 \\
4-25-52\end{array}$ & 1,730 & $\begin{array}{l}-- \\
--\end{array}$ & $\begin{array}{l}-- \\
--\end{array}$ & $\begin{array}{l}120 \\
120\end{array}$ & $\begin{array}{r}70 \\
100\end{array}$ & $\begin{array}{r}110 \\
94\end{array}$ \\
\hline
\end{tabular}

Footnotes at end of table. 


\begin{tabular}{|c|c|c|c|c|c|c|c|}
\hline $\begin{array}{l}\text { Potassium, } \\
\text { dissolved } \\
(\mathrm{mg} / \mathrm{L})\end{array}$ & $\begin{array}{l}\text { Alkalinity, } \\
\text { total, field } \\
(\mathrm{mg} / \mathrm{L} \text { as } \\
\left.\mathrm{CaCO}_{3}\right)\end{array}$ & $\begin{array}{c}\text { Sulfate, } \\
\text { dissolved } \\
(\mathrm{mg} / \mathrm{L})\end{array}$ & $\begin{array}{c}\text { Chloride, } \\
\text { dissolved } \\
\text { (mg/L) }\end{array}$ & $\begin{array}{l}\text { Solids, sum of } \\
\text { constituents, } \\
\text { dissolved } \\
(\mathrm{mg} / \mathrm{L})\end{array}$ & $\begin{array}{c}\text { Nitrogen, } \\
\text { nitrite plus nitrate, } \\
\text { dissolved } \\
(\mathrm{mg} / \mathrm{L} \text { as } \mathrm{N})\end{array}$ & $\begin{array}{l}\text { Boron, } \\
\text { dissolved } \\
(\mu \mathrm{g} / \mathrm{L})\end{array}$ & $\begin{array}{c}\text { Manganese, } \\
\text { dissolved } \\
(\mu \mathrm{g} / \mathrm{L})\end{array}$ \\
\hline \multicolumn{8}{|c|}{ Upper Aquifer--Main Zone--Continued } \\
\hline $\begin{array}{c}3.9 \\
2.3 \\
2.2 \\
2.3 \\
2.7 \\
3.6 \\
3.8 \\
3.7 \\
3.7 \\
3.9 \\
3.8 \\
3.9 \\
5.2 \\
6.3 \\
54 \\
--\end{array}$ & $\begin{array}{r}355 \\
361 \\
374 \\
388 \\
376 \\
\text { L397 } \\
\text { L395 } \\
\text { L385 } \\
\text { L398 } \\
\text { L404 } \\
\text { L383 } \\
\text { L388 } \\
\text { L412 } \\
\text { L402 } \\
\text { L416 } \\
\text { L438 }\end{array}$ & $\begin{array}{l}420 \\
580 \\
520 \\
520 \\
440 \\
500 \\
480 \\
450 \\
470 \\
490 \\
530 \\
610 \\
510 \\
500 \\
520 \\
510\end{array}$ & $\begin{array}{l}110 \\
130 \\
120 \\
120 \\
110 \\
120 \\
120 \\
110 \\
120 \\
130 \\
120 \\
130 \\
130 \\
120 \\
130 \\
150\end{array}$ & $\begin{array}{r}1,140 \\
1,300 \\
1,230 \\
1,240 \\
1,180 \\
1,300 \\
1,270 \\
1,220 \\
1,270 \\
1,320 \\
1,280 \\
1,440 \\
1,370 \\
1,330 \\
1,430 \\
31,354\end{array}$ & $\begin{array}{l}-- \\
-- \\
-- \\
-- \\
- \\
0.00 \\
.00 \\
.00 \\
.00 \\
.10 \\
.10 \\
.10 \\
.10 \\
.10 \\
.10 \\
<.10\end{array}$ & $\begin{array}{r}-- \\
-- \\
-- \\
420 \\
1 \\
500 \\
520 \\
440 \\
-- \\
530 \\
390 \\
520 \\
400 \\
400 \\
--\end{array}$ & $\begin{array}{r}120 \\
920 \\
1,000 \\
920 \\
1,100 \\
1 \\
960 \\
800 \\
1,100 \\
1,100 \\
1,100 \\
1,200 \\
1,200 \\
1,000 \\
1,100 \\
1,200\end{array}$ \\
\hline $\begin{array}{l}37 \\
22\end{array}$ & $\begin{array}{l}366 \\
386\end{array}$ & $\begin{array}{l}400 \\
420\end{array}$ & $\begin{array}{l}1,500 \\
1,300\end{array}$ & $\begin{array}{l}3,230 \\
3,130\end{array}$ & $\begin{array}{l}<.10 \\
<.10\end{array}$ & $\begin{array}{l}450 \\
440\end{array}$ & $\begin{array}{l}820 \\
790\end{array}$ \\
\hline $\begin{array}{l}20 \\
15 \\
13\end{array}$ & $\begin{array}{l}404 \\
468 \\
413\end{array}$ & $\begin{array}{l}710 \\
780 \\
780\end{array}$ & $\begin{array}{l}1,800 \\
1,800 \\
1,900\end{array}$ & $\begin{array}{l}4,190 \\
4,380 \\
4,580\end{array}$ & $\begin{array}{r}<.10 \\
<.10 \\
.48\end{array}$ & $\begin{array}{l}410 \\
420 \\
380\end{array}$ & $\begin{array}{l}2,000 \\
2,200 \\
2,200\end{array}$ \\
\hline $\begin{array}{l}9.0 \\
8.7\end{array}$ & $\begin{array}{l}509 \\
534\end{array}$ & $\begin{array}{l}550 \\
600\end{array}$ & $\begin{array}{l}430 \\
460\end{array}$ & $\begin{array}{l}1,900 \\
2,050\end{array}$ & $\begin{array}{l}<.10 \\
<.10\end{array}$ & $\begin{array}{l}320 \\
310\end{array}$ & $\begin{array}{l}1,100 \\
1,300\end{array}$ \\
\hline 8.7 & 490 & 930 & 440 & 2,530 & $<.10$ & 850 & 1,500 \\
\hline 8.5 & 426 & 690 & 320 & 1,880 & $<.10$ & 700 & 370 \\
\hline $\begin{array}{c}12 \\
13 \\
13 \\
3.6 \\
12 \\
10 \\
8.0\end{array}$ & $\begin{array}{l}406 \\
418 \\
416 \\
410 \\
428 \\
424 \\
419\end{array}$ & $\begin{array}{r}870 \\
790 \\
940 \\
1,000 \\
950 \\
930 \\
1,000\end{array}$ & $\begin{array}{l}310 \\
350 \\
370 \\
400 \\
500 \\
350 \\
390\end{array}$ & $\begin{array}{l}2,050 \\
2,040 \\
2,270 \\
2,360 \\
2,340 \\
2,210 \\
2,400\end{array}$ & $\begin{array}{r}<.10 \\
<.10 \\
<.10 \\
.64 \\
<.10 \\
<.10 \\
<.10\end{array}$ & $\begin{array}{l}550 \\
530 \\
590 \\
560 \\
520 \\
530 \\
530\end{array}$ & $\begin{array}{l}480 \\
440 \\
500 \\
480 \\
480 \\
440 \\
530\end{array}$ \\
\hline 8.5 & 161 & 230 & 300 & 1,020 & $<.10$ & 370 & 200 \\
\hline 8.6 & L426 & 600 & 290 & 1,730 & $<.10$ & 870 & -- \\
\hline 9.8 & 490 & 640 & 310 & 1,870 & $<.10$ & 870 & -- \\
\hline -- & -- & -- & -- & ${ }^{2} 1,320$ & -- & -- & -- \\
\hline$\overline{6} .6$ & $\begin{array}{l}400 \\
261\end{array}$ & $\begin{array}{l}200 \\
350\end{array}$ & $\begin{array}{l}150 \\
230\end{array}$ & $\begin{array}{r}930 \\
1,050\end{array}$ & $\begin{array}{l}-- \\
--\end{array}$ & $\begin{array}{r}300 \\
--\end{array}$ & -- \\
\hline
\end{tabular}


Table 9. Chemical analyses of ground water in the Lompoc area--Continued

\begin{tabular}{|c|c|c|c|c|c|c|c|}
\hline $\begin{array}{c}\text { State well } \\
\text { No. }\end{array}$ & Date & $\begin{array}{c}\text { Specific } \\
\text { conductance } \\
(\mu \mathrm{S} / \mathrm{cm})\end{array}$ & $\begin{array}{c}\mathrm{pH} \\
\text { (standard } \\
\text { units) }\end{array}$ & $\begin{array}{l}\text { Temperature, } \\
\text { water } \\
\left({ }^{\circ} \mathrm{C}\right)\end{array}$ & $\begin{array}{c}\text { Calcium, } \\
\text { dissolved } \\
(\mathrm{mg} / \mathrm{L})\end{array}$ & $\begin{array}{l}\text { Magnesium, } \\
\text { dissolved } \\
(\mathrm{mg} / \mathrm{L})\end{array}$ & $\begin{array}{c}\text { Sodium, } \\
\text { dissolved } \\
(\mathrm{mg} / \mathrm{L})\end{array}$ \\
\hline \multicolumn{8}{|c|}{ Upper Aquifer--Main Zone--Continued } \\
\hline $7 \mathrm{~N} / 35 \mathrm{~W}-26 \mathrm{~F} 4$ & $\begin{array}{r}9-20-54 \\
12-19-57 \\
9-18-58 \\
12-11-59 \\
4-05-60 \\
8-18-61 \\
10-10-61 \\
11-01-61 \\
6-06-62 \\
9-19-62 \\
7-22-63 \\
10-15-63 \\
5-15-64 \\
9-29-64\end{array}$ & $\begin{array}{l}1,640 \\
2,050 \\
2,040 \\
2,000 \\
2,180 \\
2,070 \\
2,160 \\
2,200 \\
2,400 \\
2,400 \\
2,190 \\
2,780 \\
2,680 \\
2,500\end{array}$ & $\begin{array}{l}-- \\
-- \\
-- \\
- \\
- \\
-- \\
- \\
-- \\
- \\
- \\
- \\
- \\
- \\
-\end{array}$ & $\begin{array}{l}18.0 \\
-- \\
-- \\
- \\
19.0 \\
-- \\
-- \\
-\overline{17.0} \\
-- \\
18.0 \\
18.0 \\
18.0 \\
--\end{array}$ & $\begin{array}{l}170 \\
170 \\
190 \\
160 \\
200 \\
160 \\
240 \\
390 \\
190 \\
230 \\
210 \\
300 \\
240 \\
280\end{array}$ & $\begin{array}{r}89 \\
120 \\
120 \\
100 \\
110 \\
120 \\
100 \\
97 \\
140 \\
150 \\
120 \\
160 \\
160 \\
140\end{array}$ & $\begin{array}{l}100 \\
120 \\
100 \\
110 \\
110 \\
110 \\
120 \\
110 \\
120 \\
110 \\
120 \\
150 \\
140 \\
160\end{array}$ \\
\hline $26 \mathrm{F5}$ & $\begin{array}{r}6-08-72 \\
12-14-82 \\
6-02-83 \\
8-30-83 \\
8-22-84 \\
6-24-87 \\
7-20-88\end{array}$ & $\begin{array}{l}2,640 \\
3,100 \\
2,730 \\
2,730 \\
1,840 \\
2,670 \\
2,300\end{array}$ & $\begin{array}{l}-- \\
7.5 \\
7.3 \\
7.5 \\
7.3 \\
7.5 \\
7.5\end{array}$ & $\begin{array}{l}18.0 \\
17.0 \\
18.5 \\
17.0 \\
18.0 \\
19.0 \\
18.5\end{array}$ & $\begin{array}{l}260 \\
300 \\
280 \\
240 \\
240 \\
230 \\
260\end{array}$ & $\begin{array}{l}140 \\
170 \\
160 \\
140 \\
130 \\
120 \\
150\end{array}$ & $\begin{array}{l}140 \\
180 \\
180 \\
160 \\
170 \\
170 \\
170\end{array}$ \\
\hline $26 \mathrm{H} 1$ & $6-01-83$ & 2,240 & 7.3 & 18.0 & 250 & 120 & 150 \\
\hline \multicolumn{8}{|c|}{ Lower Aquifer } \\
\hline $7 \mathrm{~N} / 33 \mathrm{~W}-19 \mathrm{Q} 2$ & $5-12-87$ & 806 & 7.4 & 23.5 & 61 & 22 & 60 \\
\hline $7 \mathrm{~N} / 34 \mathrm{~W}-14 \mathrm{~F} 4$ & $6-25-87$ & 740 & 7.3 & -- & 67 & 21 & 65 \\
\hline $14 \mathrm{G} 2$ & $6-25-87$ & 710 & 7.7 & 21.0 & 57 & 19 & 56 \\
\hline $15 \mathrm{D} 1$ & $\begin{array}{r}8-10-59 \\
9-28-59 \\
6-01-61 \\
8-21-61 \\
12-27-63 \\
12-28-64 \\
12-19-65 \\
12-27-65 \\
6-15-66 \\
12-27-66 \\
12-26-67 \\
12-27-69 \\
12-30-69 \\
7-23-70 \\
12-22-70 \\
1-12-72 \\
12-12-73 \\
12-10-74\end{array}$ & $\begin{array}{r}-- \\
-- \\
1,010 \\
-- \\
-- \\
-- \\
-- \\
-- \\
-- \\
-- \\
-- \\
-- \\
-- \\
-- \\
-- \\
-- \\
--\end{array}$ & $\begin{array}{l}7.6 \\
7.1 \\
8.0 \\
-7.6 \\
7.6 \\
7.8 \\
7.3 \\
8.0 \\
7.2 \\
8.3 \\
7.9 \\
7.2 \\
7.6 \\
7.3 \\
7.2 \\
7.0 \\
7.2 \\
7.0\end{array}$ & $\begin{array}{l}-- \\
-- \\
- \\
- \\
-- \\
- \\
- \\
-- \\
- \\
- \\
- \\
- \\
- \\
- \\
- \\
- \\
-\end{array}$ & $\begin{array}{r}78 \\
72 \\
92 \\
110 \\
120 \\
120 \\
120 \\
120 \\
140 \\
140 \\
140 \\
120 \\
130 \\
140 \\
130 \\
120 \\
130 \\
130\end{array}$ & $\begin{array}{l}28 \\
32 \\
34 \\
13 \\
17 \\
19 \\
20 \\
25 \\
21 \\
17 \\
26 \\
20 \\
17 \\
32 \\
20 \\
21 \\
18 \\
17\end{array}$ & $\begin{array}{r}78 \\
75 \\
71 \\
68 \\
86 \\
76 \\
91 \\
82 \\
98 \\
98 \\
83 \\
110 \\
100 \\
79 \\
88 \\
93 \\
89 \\
86\end{array}$ \\
\hline
\end{tabular}




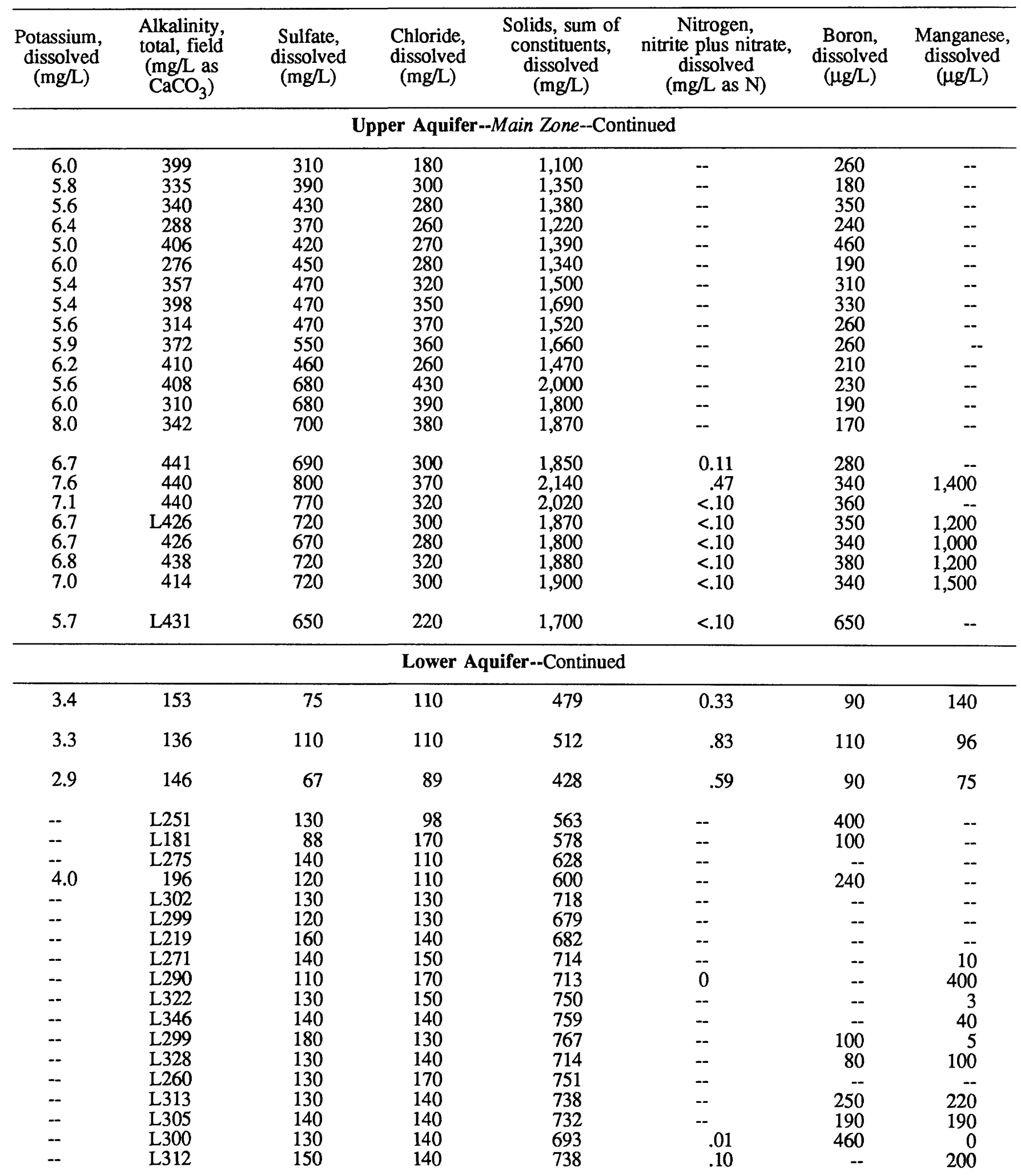


Table 9. Chemical analyses of ground water in the Lompoc area--Continued

\begin{tabular}{|c|c|c|c|c|c|c|c|}
\hline $\begin{array}{c}\text { State well } \\
\text { No. }\end{array}$ & Date & $\begin{array}{l}\text { Specific } \\
\text { conductance } \\
(\mu \mathrm{S} / \mathrm{cm})\end{array}$ & $\begin{array}{c}\mathrm{pH} \\
\text { (standard } \\
\text { units) }\end{array}$ & $\begin{array}{c}\text { Temperature, } \\
\text { water } \\
\left({ }^{\circ} \mathrm{C}\right)\end{array}$ & $\begin{array}{l}\text { Calcium, } \\
\text { dissolved } \\
(\mathrm{mg} / \mathrm{L})\end{array}$ & $\begin{array}{l}\text { Magnesium, } \\
\text { dissolved } \\
(\mathrm{mg} / \mathrm{L})\end{array}$ & $\begin{array}{c}\text { Sodium, } \\
\text { dissolved } \\
(\mathrm{mg} / \mathrm{L})\end{array}$ \\
\hline \multicolumn{8}{|c|}{ Lower Aquifer--Continued } \\
\hline $7 \mathrm{~N} / 34 \mathrm{~W}-15 \mathrm{D} 1--$ & $\begin{array}{l}\text { led } \\
12-11-74 \\
01-07-76 \\
11-16-76 \\
10-14-77 \\
2-01-78 \\
1-26-81\end{array}$ & $\begin{array}{r}-- \\
-- \\
- \\
1,000 \\
- \\
--\end{array}$ & $\begin{array}{l}7.4 \\
7.3 \\
7.3 \\
7.8 \\
7.2\end{array}$ & $\begin{array}{l}-- \\
-- \\
-\overline{25.0} \\
-- \\
--\end{array}$ & $\begin{array}{r}130 \\
120 \\
95 \\
120 \\
82 \\
110\end{array}$ & $\begin{array}{l}16 \\
18 \\
17 \\
18 \\
12 \\
24\end{array}$ & $\begin{array}{l}86 \\
73 \\
96 \\
87 \\
79 \\
64\end{array}$ \\
\hline $15 \mathrm{D} 3$ & $4-15-88$ & -- & -- & -- & -- & -- & -- \\
\hline $15 \mathrm{E} 3$ & $1-07-88$ & 800 & 6.8 & 21.5 & 57 & 17 & 72 \\
\hline $20 \mathrm{~K} 6$ & $\begin{array}{l}6-25-87 \\
6-22-88\end{array}$ & $\begin{array}{l}1,140 \\
1,040\end{array}$ & $\begin{array}{l}7.7 \\
7.7\end{array}$ & $\begin{array}{l}21.0 \\
21.5\end{array}$ & $\begin{array}{l}130 \\
120\end{array}$ & $\begin{array}{l}27 \\
27\end{array}$ & $\begin{array}{l}79 \\
71\end{array}$ \\
\hline $20 \mathrm{P} 3$ & $5-08-87$ & 1,010 & 7.3 & -- & 13 & 26 & 120 \\
\hline $27 \mathrm{~K} 6^{1}$ & $\begin{array}{r}10-30-87 \\
1-07-88 \\
4-11-88 \\
7-21-88\end{array}$ & $\begin{array}{r}-- \\
971 \\
1,050 \\
990\end{array}$ & $\begin{array}{l}7.7 \\
7.8 \\
7.6 \\
7.6\end{array}$ & $\begin{array}{l}19.0 \\
20.0 \\
19.0 \\
20.0\end{array}$ & $\begin{array}{r}100 \\
90 \\
89 \\
82\end{array}$ & $\begin{array}{l}32 \\
31 \\
29 \\
26\end{array}$ & $\begin{array}{l}92 \\
95 \\
91 \\
82\end{array}$ \\
\hline $29 \mathrm{~N} 7^{1}$ & $\begin{array}{r}3-18-87 \\
5-06-87 \\
6-25-87 \\
10-28-87 \\
1-06-88 \\
4-12-88 \\
7-23-88\end{array}$ & $\begin{array}{l}1,470 \\
1,480 \\
1,420 \\
1,490 \\
1,560 \\
1,490 \\
1,470\end{array}$ & $\begin{array}{l}7.7 \\
7.7 \\
7.8 \\
7.6 \\
7.4 \\
7.4 \\
7.4\end{array}$ & $\begin{array}{l}-. \\
20.0 \\
19.0 \\
19.0 \\
18.5 \\
19.0 \\
18.5\end{array}$ & $\begin{array}{l}130 \\
130 \\
150 \\
140 \\
150 \\
150 \\
140\end{array}$ & $\begin{array}{l}49 \\
51 \\
51 \\
51 \\
51 \\
54 \\
53\end{array}$ & $\begin{array}{l}120 \\
130 \\
110 \\
110 \\
110 \\
110 \\
110\end{array}$ \\
\hline $7 \mathrm{~N} / 35 \mathrm{~W}-26 \mathrm{~L} 4^{1}$ & $\begin{array}{r}10-30-87 \\
1-05-88 \\
4-12-88 \\
7-23-88\end{array}$ & $\begin{array}{l}1,440 \\
1,550 \\
1,230 \\
1,150\end{array}$ & $\begin{array}{l}7.9 \\
7.5 \\
7.4 \\
7.2\end{array}$ & $\begin{array}{l}18.5 \\
-\overline{20.0} \\
20.0\end{array}$ & $\begin{array}{r}140 \\
150 \\
86 \\
78\end{array}$ & $\begin{array}{l}44 \\
48 \\
39 \\
43\end{array}$ & $\begin{array}{l}86 \\
83 \\
67 \\
70\end{array}$ \\
\hline $33 \mathrm{~J} 2$ & $\begin{array}{l}6-26-87 \\
6-22-88\end{array}$ & $\begin{array}{l}702 \\
687\end{array}$ & $\begin{array}{l}7.5 \\
7.4\end{array}$ & $\begin{array}{l}18.0 \\
18.0\end{array}$ & $\begin{array}{l}37 \\
34\end{array}$ & $\begin{array}{l}20 \\
19\end{array}$ & $\begin{array}{l}81 \\
77\end{array}$ \\
\hline $33 \mathrm{~J} 4$ & $\begin{array}{l}6-26-87 \\
6-22-88\end{array}$ & $\begin{array}{l}1,070 \\
1,060\end{array}$ & $\begin{array}{l}7.8 \\
7.7\end{array}$ & $\begin{array}{l}18.5 \\
19.0\end{array}$ & $\begin{array}{l}100 \\
110\end{array}$ & $\begin{array}{l}32 \\
34\end{array}$ & $\begin{array}{l}71 \\
72\end{array}$ \\
\hline $35 \mathrm{E} 1$ & $5-14-87$ & 607 & 7.2 & 19.0 & 24 & 11 & 74 \\
\hline
\end{tabular}

${ }^{1}$ Isotope data are given in table 6.

${ }_{2}^{2}$ Dissolved-solids concentration computed from specific conductance.

${ }^{3}$ Solids, sum of constituents, dissolved, value does not include potassium. 


\begin{tabular}{|c|c|c|c|c|c|c|c|}
\hline $\begin{array}{l}\text { Potassium, } \\
\text { dissolved } \\
(\mathrm{mg} / \mathrm{L})\end{array}$ & $\begin{array}{l}\text { Alkalinity, } \\
\text { total, field } \\
(\mathrm{mg} / \mathrm{L} \text { as } \\
\left.\mathrm{CaCO}_{3}\right)\end{array}$ & $\begin{array}{l}\text { Sulfate, } \\
\text { dissolved } \\
(\mathrm{mg} / \mathrm{L})\end{array}$ & $\begin{array}{c}\text { Chloride, } \\
\text { dissolved } \\
\text { (mg/L) }\end{array}$ & $\begin{array}{l}\text { Solids, sum of } \\
\text { constituents, } \\
\text { dissolved } \\
(\mathrm{mg} / \mathrm{L})\end{array}$ & $\begin{array}{c}\text { Nitrogen, } \\
\text { nitrite plus nitrate, } \\
\text { dissolved } \\
(\mathrm{mg} / \mathrm{L} \text { as } \mathrm{N})\end{array}$ & $\begin{array}{l}\text { Boron, } \\
\text { dissolved } \\
(\mu \mathrm{g} / \mathrm{L})\end{array}$ & $\begin{array}{c}\text { Manganese, } \\
\text { dissolved } \\
(\mu \mathrm{g} / \mathrm{L})\end{array}$ \\
\hline \multicolumn{8}{|c|}{ Lower Aquifer--Continued } \\
\hline $\begin{array}{l}-- \\
-- \\
- \\
3.8 \\
-- \\
--\end{array}$ & $\begin{array}{r}\text { L297 } \\
\text { L180 } \\
\text { L220 } \\
230 \\
\text { L220 } \\
\text { L210 }\end{array}$ & $\begin{array}{l}130 \\
170 \\
120 \\
140 \\
100 \\
120\end{array}$ & $\begin{array}{l}150 \\
140 \\
130 \\
140 \\
120 \\
140\end{array}$ & $\begin{array}{l}711 \\
644 \\
590 \\
647 \\
525 \\
587\end{array}$ & $\begin{array}{l}0.10 \\
15 \\
-- \\
-- \\
-- \\
3.0\end{array}$ & $\begin{array}{r}400 \\
-- \\
200 \\
300 \\
--\end{array}$ & $\begin{array}{r}240 \\
300 \\
170 \\
-- \\
170 \\
420\end{array}$ \\
\hline -- & -- & -- & -- & -- & -- & -- & -- \\
\hline 3.9 & L87 & 110 & 130 & 503 & .36 & 110 & 160 \\
\hline $\begin{array}{l}3.6 \\
3.4\end{array}$ & $\begin{array}{l}246 \\
254\end{array}$ & $\begin{array}{l}180 \\
160\end{array}$ & $\begin{array}{l}110 \\
120\end{array}$ & $\begin{array}{l}728 \\
701\end{array}$ & $\begin{array}{r}<.10 \\
.16\end{array}$ & $\begin{array}{l}190 \\
170\end{array}$ & $\begin{array}{l}290 \\
320\end{array}$ \\
\hline 7.6 & 85 & 210 & 130 & 562 & $<.10$ & 280 & 14 \\
\hline $\begin{array}{l}- \\
5.2 \\
4.2 \\
4.5\end{array}$ & $\begin{array}{r}\text { L240 } \\
\text { L175 } \\
\text { L218 } \\
220\end{array}$ & $\begin{array}{l}180 \\
230 \\
170 \\
190\end{array}$ & $\begin{array}{l}90 \\
93 \\
80 \\
83\end{array}$ & $\begin{array}{l}-- \\
691 \\
636 \\
639\end{array}$ & $\begin{array}{l}<.10 \\
<.10 \\
<.10 \\
<.10\end{array}$ & $\begin{array}{l}250 \\
240 \\
230\end{array}$ & $\begin{array}{r}0 \\
43 \\
69 \\
50\end{array}$ \\
\hline $\begin{array}{l}4.8 \\
5.0 \\
4.3 \\
5.1 \\
4.5 \\
3.9 \\
4.3\end{array}$ & $\begin{array}{l}345 \\
350 \\
366 \\
390 \\
360 \\
386 \\
346\end{array}$ & $\begin{array}{l}320 \\
330 \\
330 \\
430 \\
340 \\
340 \\
340\end{array}$ & $\begin{array}{l}100 \\
110 \\
110 \\
110 \\
110 \\
110 \\
110\end{array}$ & $\begin{array}{r}931 \\
1,010 \\
1,010 \\
1,120 \\
1,020 \\
1,040 \\
1,000\end{array}$ & $\begin{array}{r}<.10 \\
.22 \\
<.10 \\
<.10 \\
<.10 \\
<.10 \\
<.10\end{array}$ & $\begin{array}{l}480 \\
510 \\
490 \\
500 \\
470 \\
490 \\
470\end{array}$ & $\begin{array}{r}170 \\
250 \\
87 \\
84 \\
99 \\
100 \\
77\end{array}$ \\
\hline $\begin{array}{l}7.0 \\
10 \\
11 \\
6.0\end{array}$ & $\begin{array}{l}291 \\
282 \\
242 \\
244\end{array}$ & $\begin{array}{l}210 \\
220 \\
140 \\
140\end{array}$ & $\begin{array}{l}270 \\
180 \\
150 \\
150\end{array}$ & $\begin{array}{l}980 \\
913 \\
688 \\
692\end{array}$ & $\begin{array}{l}<.10 \\
<.10 \\
<.10 \\
.24\end{array}$ & $\begin{array}{l}120 \\
110 \\
150 \\
140\end{array}$ & $\begin{array}{r}48 \\
100 \\
120 \\
94\end{array}$ \\
\hline $\begin{array}{l}2.9 \\
2.8\end{array}$ & $\begin{array}{l}113 \\
113\end{array}$ & $\begin{array}{l}38 \\
39\end{array}$ & $\begin{array}{l}130 \\
130\end{array}$ & $\begin{array}{l}423 \\
414\end{array}$ & $\begin{array}{l}2.5 \\
2.2\end{array}$ & $\begin{array}{l}90 \\
80\end{array}$ & $\begin{array}{l}<1 \\
<1\end{array}$ \\
\hline $\begin{array}{l}4.7 \\
4.1\end{array}$ & $\begin{array}{l}190 \\
192\end{array}$ & $\begin{array}{l}110 \\
120\end{array}$ & $\begin{array}{l}180 \\
180\end{array}$ & $\begin{array}{l}661 \\
686\end{array}$ & $\begin{array}{l}.22 \\
.20\end{array}$ & $\begin{array}{l}60 \\
60\end{array}$ & $\begin{array}{l}40 \\
50\end{array}$ \\
\hline 2.6 & 48 & 23 & 120 & 368 & 10 & 50 & 3 \\
\hline
\end{tabular}


Table 10. Chemical analyses for selected streams in the Lompoc area, 1987-88

$\left[\mu \mathrm{S} / \mathrm{cm}\right.$, microsiemens per centimeter at $25^{\circ} \mathrm{C}$; ${ }^{\circ} \mathrm{C}$, degree Celsius; $\mathrm{mg} / \mathrm{L}$, milligrams per liter; $\mu \mathrm{g} / \mathrm{L}$, micrograms per liter;

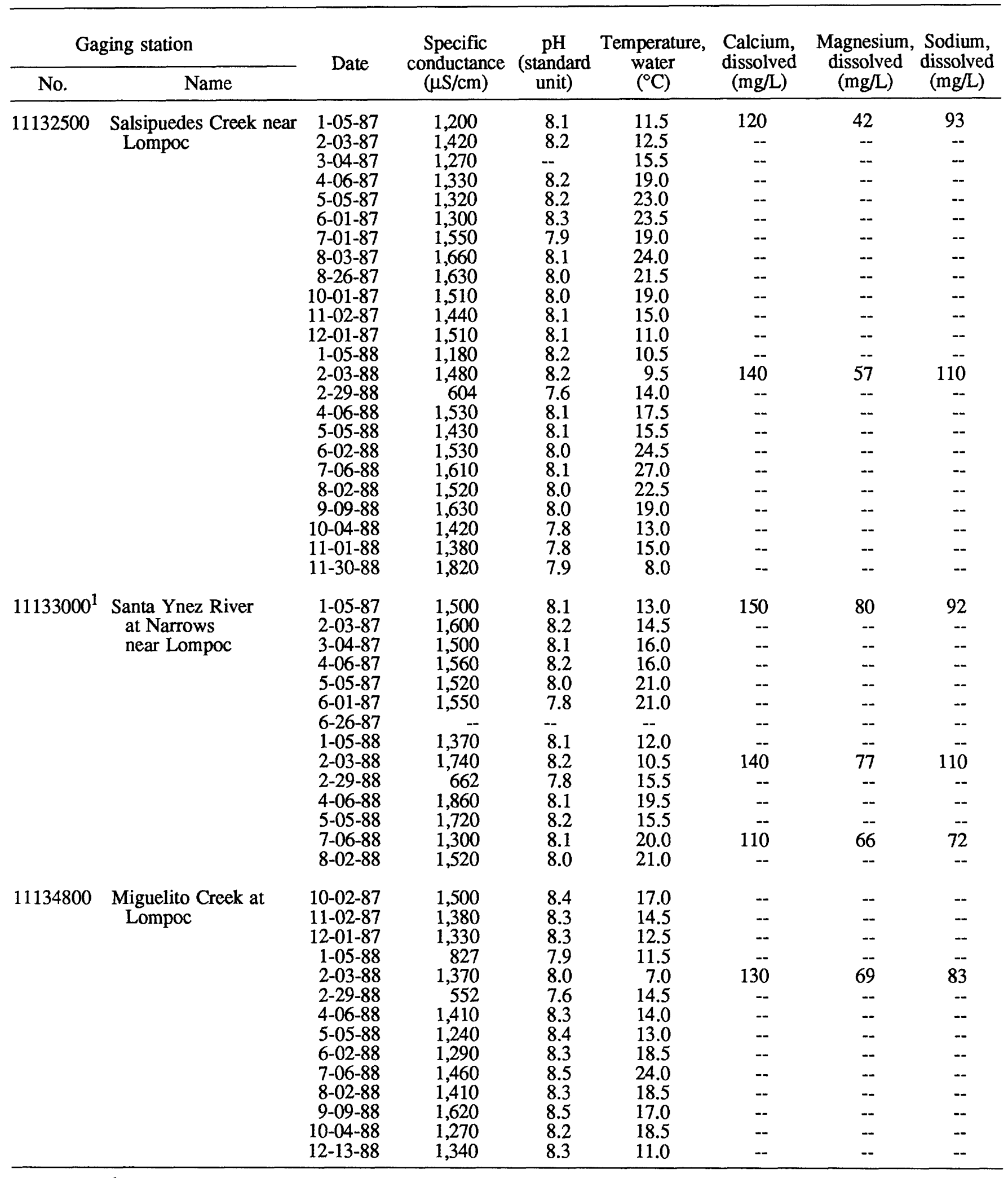

${ }^{1}$ Isotope data are given in table 6. 
$<$, actual value is less than value shown; --, no data]

\begin{tabular}{|c|c|c|c|c|c|c|c|}
\hline $\begin{array}{l}\text { Potassium, } \\
\text { dissolved } \\
(\mathrm{mg} / \mathrm{L})\end{array}$ & $\begin{array}{c}\text { Alkalinity, } \\
\text { total, field } \\
(\mathrm{mg} / \mathrm{L} \text { as } \\
\left.\mathrm{CaCO}_{3}\right) \\
\end{array}$ & $\begin{array}{c}\text { Sulfate, } \\
\text { dissolved } \\
(\mathrm{mg} / \mathrm{L})\end{array}$ & $\begin{array}{c}\text { Chloride, } \\
\text { dissolved } \\
(\mathrm{mg} / \mathrm{L})\end{array}$ & $\begin{array}{l}\text { Solids, residue } \\
\text { at } 180^{\circ} \mathrm{C}, \\
\text { dissolved } \\
(\mathrm{mg} / \mathrm{L})\end{array}$ & $\begin{array}{c}\text { Nitrogen, } \\
\text { nitrite plus nitrate, } \\
\text { dissolved } \\
(\mathrm{mg} / \mathrm{L} \text { as } \mathrm{N}) \\
\end{array}$ & $\begin{array}{l}\text { Boron, } \\
\text { dissolved } \\
(\mu \mathrm{g} / \mathrm{L})\end{array}$ & $\begin{array}{c}\text { Manganese, } \\
\text { dissolved } \\
(\mu \mathrm{g} / \mathrm{L})\end{array}$ \\
\hline 2.8 & 297 & 250 & 93 & 801 & $<0.100$ & 530 & 34 \\
\hline-- & -- & -- & - & 943 & -- & -- & -- \\
\hline -- & -- & -- & -- & 942 & -- & -- & -- \\
\hline -- & -- & -- & -- & 919 & -- & -- & -- \\
\hline-- & -- & -- & -- & 945 & -- & -- & -- \\
\hline -- & -- & -- & -- & 946 & -- & -- & -- \\
\hline-- & -- & -- & -- & 1,020 & -- & -- & -- \\
\hline-- & -- & -- & -- & 1,120 & -- & -- & -- \\
\hline -- & -- & -- & -. & 1,130 & -- & -- & -- \\
\hline -- & -- & -- & -- & 1,110 & -- & -- & -- \\
\hline -- & -. & -. & -. & 970 & -. & -- & -- \\
\hline -- & -- & -- & -- & 1,010 & -- & -- & -- \\
\hline-- & -- & -- & -- & 824 & -- & -- & -- \\
\hline 3.1 & 374 & 280 & 120 & 994 & $<.100$ & 650 & 120 \\
\hline-- & -- & -- & -- & 374 & -- & - & -- \\
\hline-- & -- & -- & -- & 990 & -- & -- & -- \\
\hline-- & -- & -- & -- & 964 & -- & -- & -- \\
\hline-- & -- & -- & -- & 967 & -- & -- & -- \\
\hline-- & -- & -- & -- & 1,060 & -- & -- & -- \\
\hline-- & -- & -- & -- & 1,080 & -- & -- & -- \\
\hline-- & -- & -- & -- & 1,080 & -- & -- & -- \\
\hline-- & -- & -- & -- & 1,090 & -- & -- & -- \\
\hline-- & -- & -- & -- & 1,140 & -- & -- & -- \\
\hline-- & -- & -- & -- & 1,270 & -- & -- & -- \\
\hline 3.5 & 308 & 450 & 96 & 1,110 & $<.100$ & 500 & 15 \\
\hline -- & -- & -- & -. & 1,220 & -- & -- & -- \\
\hline-- & -- & -- & -- & 1,230 & -- & -- & -. \\
\hline -- & -- & -- & -- & 1,180 & -- & -- & .. \\
\hline-- & -- & -- & -- & 1,270 & -- & -- & .- \\
\hline -- & -- & -- & -- & 1,280 & -. & -- & -- \\
\hline-- & -- & -- & -- & - & -- & -- & -- \\
\hline-- & - & -- & -- & 919 & -- & -- & -- \\
\hline 4.5 & 361 & 480 & 120 & 1,280 & $<.100$ & 530 & 50 \\
\hline-- & -- & -- & -- & 410 & -- & -- & - \\
\hline-- & -- & -- & -- & 1,260 & -- & -- & -- \\
\hline-- & -- & -- & -- & 1,270 & -- & -- & -- \\
\hline 4.0 & 251 & 370 & 54 & 904 & $<.100$ & 430 & $<1$ \\
\hline-- & - & - & - & 1,170 & -- & - & -- \\
\hline-- & -- & -- & -- & 1,010 & -- & --. & \\
\hline-- & -- & -- & -- & 976 & -- & -- & -- \\
\hline-- & -- & -- & -- & 889 & -. & -- & -- \\
\hline-- & -- & -- & -- & 525 & -- & -- & -- \\
\hline 2.5 & 372 & 260 & 100 & 940 & .230 & 130 & 80 \\
\hline-- & -- & -- & -- & 347 & -- & -- & -- \\
\hline-- & -- & -- & -- & 930 & -- & -- & -- \\
\hline-- & -- & -- & -- & 869 & -- & -- & -- \\
\hline-- & -- & -- & -- & 852 & -- & -- & -- \\
\hline-- & -- & -- & -- & 1,010 & -- & -- & -- \\
\hline-- & -- & -- & -- & 1,040 & -- & -- & -- \\
\hline-- & -- & -- & -- & 1,100 & -- & -- & -- \\
\hline-- & -- & -- & -- & 1,020 & -- & -- & -- \\
\hline -- & -- & -- & -- & 921 & -- & -- & -- \\
\hline
\end{tabular}

